Mutation Research, 65 (1979) 289-356

(C) Elsevier/North-Holland Biomedical Press

\title{
IN VIVO COVALENT BINDING OF ORGANIC CHEMICALS TO DNA AS A QUANTITATIVE INDICATOR IN THE PROCESS OF CHEMICAL CARCINOGENESIS
}

\section{WERNER K. LUTZ}

Institute of Toxicology, Swiss Federal Institute of Technology and University of Zurich, CH-8603 Schwerzenbach (Switzerland)

(Received 21 December 1978)

(Revision received 24 April 1979)

(Accepted 1 May 1979)

\section{Contents}

1. Introduction $\ldots \ldots \ldots \ldots \ldots \ldots \ldots \ldots \ldots \ldots \ldots \ldots \ldots \ldots \ldots$

1.1. Mechanism of action of organic carcinogens . . . . . . . . . . 291

1.2. Short-term tests for the detection of chemical carcinogens. Quantitative carcinogenesis ......................... 293

1.3. Covalent binding of chemical carcinogens to biological macromolecules ... 294

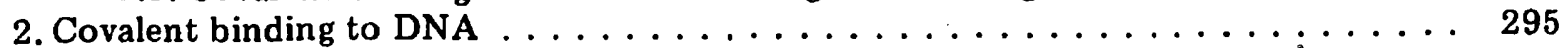

2.1. Introduction. In vivo versus in vitro $\ldots \ldots \ldots \ldots \ldots \ldots \ldots \ldots$

2.2. The in vivo "Covalent Binding Index": CBI . . . . . . . . . . . . 297

2.3. Choice of experimental conditions for the measurement of a CBI . . . . . 298

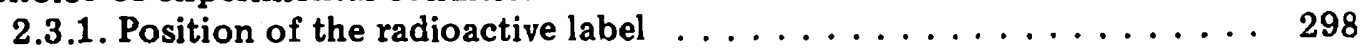

2.3.2. Dose and dose schedule . . . . . . . . . . . . . . . . . 299

2.3.3. Solvent and route of administration . . . . . . . . . 300

2.3.4. Time between administration and sacrifice . . . . . . . . 302

2.3.5. Isolation of DNA. Liquid-scintillation counting . . . . . . . . 303

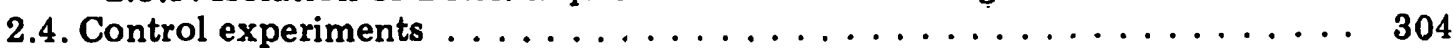

2.4.1. Background radioactivity . . . . . . . . . . . . 305

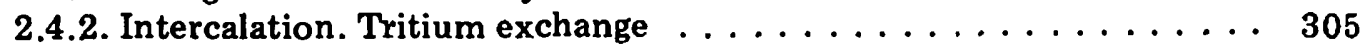

2.4.3. Biosynthetic incorporation of radioactivity . . . . . . . 305

3. Lists of chemicals that have been tested for covalent binding to biological macromolecules under various experimental conditions $\ldots \ldots \ldots \ldots \ldots \ldots \ldots \ldots \ldots$

3.1. Introduction . . . . . . . . . . . . . . . . . 307

3.2. Covalent binding to DNA in vivo. Calculation of a CBI . . . . . . . 313

3.3. Covalent binding to DNA in vivo. No calculation of a CBI possible . . . . . 315

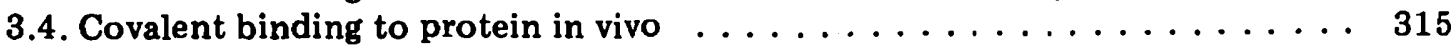

3.5. Covalent binding to nucleic acids or protein in vitro . . . . . . . 323

3.6. Compounds for which no covalent binding to nucleic acids was found . . . 323

4. Correlation of carcinogenicity with DNA binding . . . . . . . . . . . 324

4.1. Quantitative correlation of CBI for liver DNA with hepatocarcinogenicity . . 324

4.2. CBI and organotropy . . . . . . . . . . . . . . . . . 329

4.2.1. Non-hepatocarcinogens and their CBI for liver DNA . . . . . . 329

4.2.2. CBI for other organs versus carcinogenic organotropy . . . . . 330

Information regarding reprints of this article may be obtained from the publisher. (In the United States and Canada: Elsevier/North-Holland Inc., 52 Vanderbilt Ave., New York, NY 10017. In all other countries: Elsevier/North-Holland Biomedical Press, P.O. Box 211, 1000 AE Amsterdam, The Netherlands.) 
4.3. Refinements in the measurement of DNA binding for an improved quantita-

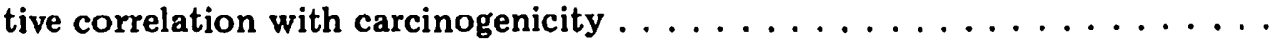

4.3.1. Pattern of DNA-binding sites $\ldots \ldots \ldots \ldots \ldots \ldots$

4.3.2. DNA repair as an organotropic modulating factor in chemical carcinogenesis. Persistence of DNA binding . . . . . . . . . . .

4.4. Mutagenicity of a specific type of DNA damage . . . . . . . . . . . .

5. Modulations of the carcinogenic response that can be studied on the basis of DNA

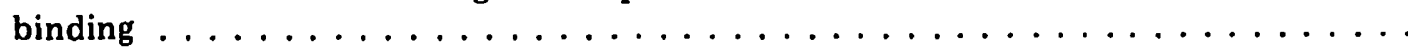

5.1. Pretreatments and their influence on DNA binding in vivo and carcinogeni-

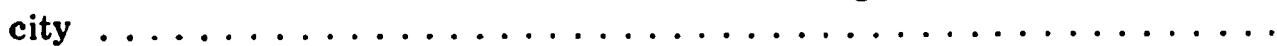

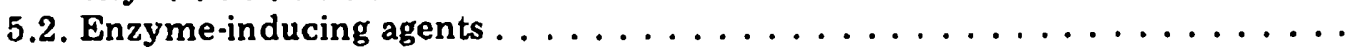

5.3. Antioxidants, special diets, hormones, surgery . . . . . . . . . . .

5.4. Effect of dose and dose schedule on the CBI . . . . . . . . . . . .

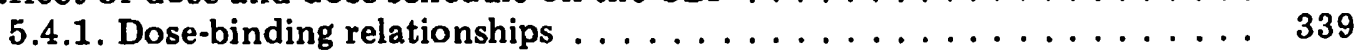

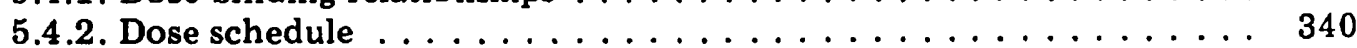

5.4.3. More than one carcinogen at a time . . . . . . . . . . . . . . . 340

6. Modulatory factors in chemical carcinogenesis which cannot or not completely be studied on the basis of DNA binding . . . . . . . . . . . . . . . . . . . 341

6.1. Modulation of the events between DNA binding and tumor . . . . . . . . 341

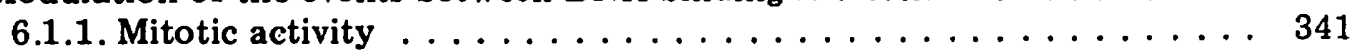

6.1.2. Promoters and hormones . . . . . . . . . . . . . . . 342

6.1.3. Probability of transformation. Immunology . . . . . . . . . . . . 342

6.2. Whole-system responses . . . . . . . . . . . . . . . . . . . . 342

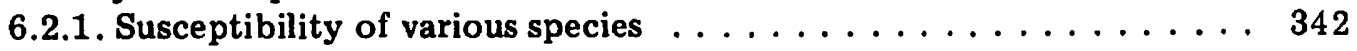

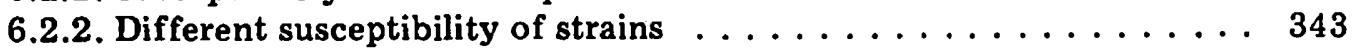

6.2.3. Differences from sex and age . . . . . . . . . . . . . . . . 344

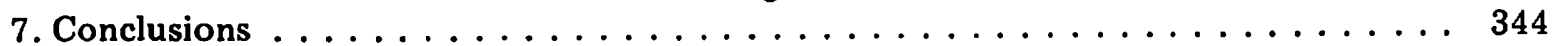

References .................................... 345

\section{Summary}

The covalent binding of chemical carcinogens to DNA of mammalian organs is expressed per unit dose, and a 'Covalent-Binding Index', CBI, is defined. CBI for various carcinogens span over 6 orders of magnitude. A similar range is observed for the carcinogenic potency in long-term bioassays on carcinogenicity.

For the assessment of a risk from exposure to a carcinogen, the total DNA damage can be estimated if the actual dose is also accounted for.

A detailed description is given for planning and performing a DNA-binding assay.

A complete literature survey on DNA binding in vivo ( 83 compounds) is given with a calculation of $\mathrm{CBI}$, where possible, 153 compounds are listed where a covalent binding to any biological macromolecule has been shown in vivo or in vitro. Recent, so far unpublished findings with aflatoxin $M_{1}$, macromolecule-bound aflatoxin $B_{1}$, diethylstilbestrol, and 1,2epithiobutyronitrile are included.

A comparison of CBI for rat-liver DNA with hepatocarcinogenic potency reveals a surprisingly good quantitative correlation.

Refinements for a DNA-binding assay are proposed. Possibilities and limitations in the use of DNA binding in chemical carcinogenesis are discussed extensively. 


\section{Introduction}

\subsection{Mechanism of action of organic carcinogens}

The immense structural variety of organic chemical carcinogens [as reviewed in 161,211 ] posed, for a long time, great difficulties in the understanding of the mechanism of carcinogenic action. Today, there is substantial evidence for a uniform sequence of events governing the process of tumor formation after exposure to an organic carcinogen. This process is shown schematically in Fig. 1 and has been summarized before $[69,91,178]$.

Most carcinogenic chemicals can undergo a covalent binding to biological macromolecules either by themselves or after metabolic activation to a chemically reactive form, the so-called ultimate carcinogen. This binding to a biological macromolecule can lead to heritable cellular damage, most directly if the target is DNA. If such DNA damage is not properly repaired before the cell divides, a mutation can be produced and form the basis for a cell transformation and possible development into a tumor.

Besides this so-called "genotoxic" mode of reaction, with DNA as target molecule, the chemically reactive forms of the carcinogens interact at the same time with various RNAs and proteins. Some of these macromolecules play an important role in cellular growth control or DNA replication so that "epigenetic" possibilities for the mechanism of tumor initiation cannot be excluded. There is, however, increasing evidence that binding to DNA correlates better with tumor incidence than does binding to RNA or protein (section 2.1).

The general process of the metabolic activation involves oxidation of the carcinogen to electrophilic derivatives by the cellular mixed function oxidases which are located in the endoplasmic reticulum and, with much less activity, in the nuclear envelope. A natural function of this complex series of enzymes appears to be the conversion of hydrophobic chemicals into hydrophilic, easily excreted compounds. Thus, it is an irony of nature that an enzyme system apparently designed for detoxification may also be responsible for the activation of chemically inert compounds into reactive carcinogens. Fig. 2 shows a

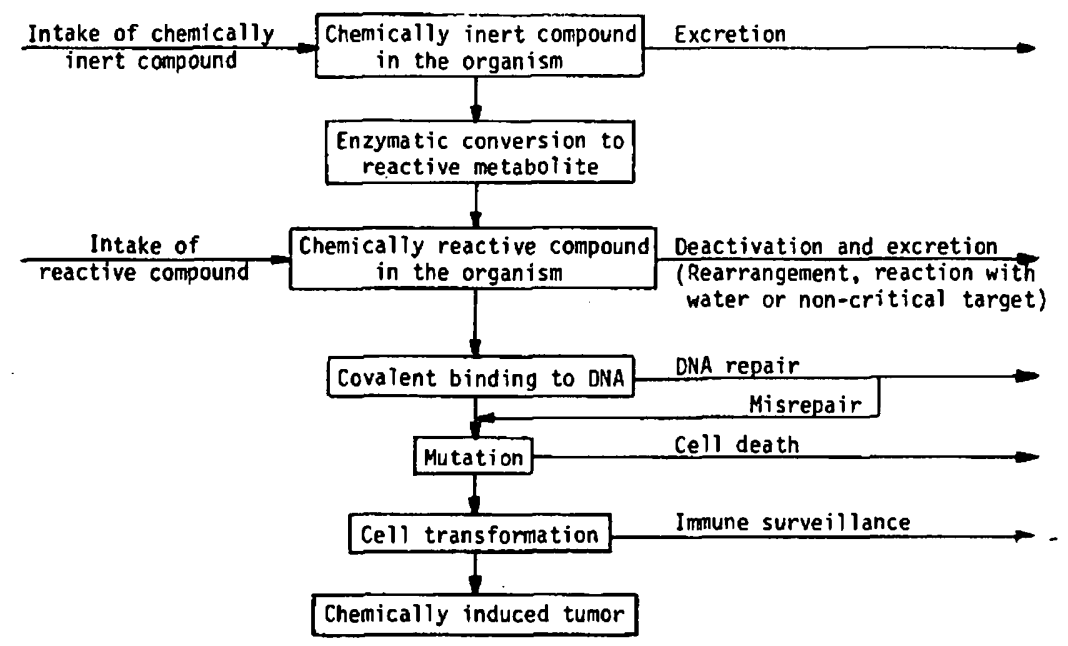

Fig. 1. Sequence of events in the chemical induction of a tumor. From the left to the center: Intake of the chemical. From the center to the right: Reactions of the chemical or of the organism which do not lead to heritable damage or a tumor. From top to bottom: Stepwise progression of the tumor. 
1<smiles>CS(=O)(=O)OC1CC1</smiles>

2<smiles>IC1OC1C1CO1</smiles>

3<smiles>C[C@@H]1COO1</smiles>

4<smiles>CSC[C@@H](Cl)I</smiles>

5

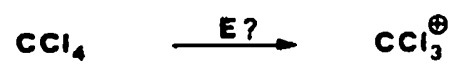

6<smiles>CC(C)C[C@H]1C(O)C(O)C2=C(CCCC2)[C@@]2(C)O[C@@H]12</smiles>

7

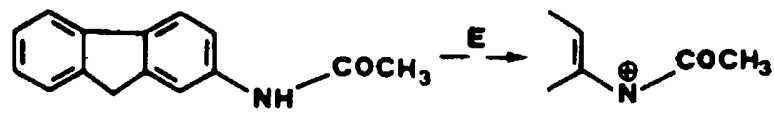

8

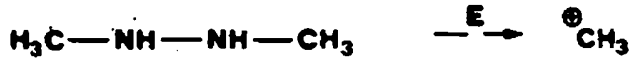

-<smiles>COc1cc2c(c3oc(=O)c4c(c13)CCC4=O)C1CCOC1O2</smiles><smiles>C[13CH][13CH]</smiles>

10

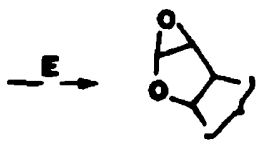

Fig. 2. Selection of organic carcinogens of different chemical classes with a known or strongly suspected electrophilic center (arrow) or chemically reactive derivative (on the right), the ultimate carcinogen. $E$. enzymatic activation required; 1 , methyl methanesulphonate; $2,1,2,3,4$-diepoxybutane; 3 , $\beta$-proplolactone; 4, a sulphur mustard; 5 , carbon tetrachloride; 6 , a polycyclic aromatic hydrocarbon (the reactive metabolite shown is known from benzo[a]pyrene); 7, 2-acetylaminofluorene; 8, 1,2-dimethylhydrazine; 9, $N, N$-dimethylnitrosamine; 10 , aflatoxin $B_{1}$.

few examples of chemical carcinogens together with the known or strongly suspected electrophilic, chemically reactive metabolites. This aspect of metabolic activation has been reviewed extensively $[161,282]$ and is also a topic of the other reviews cited in this chapter.

A number of compounds like antioxidants, enzyme-inducing or enzymeinhibitory agents have an influence on the activation/inactivation pathways in the metabolism of chemical carcinogens [281]. Such compounds have been shown to alter the tumor incidence and the extent of covalent binding of carcinogens to cellular macromolecules and the results are discussed in chapter 5 .

After these initiating events in tumor induction there is a necessary and long 
period of "promotion". A variety of chemicals act at this stage, on the mechanisms which govern the side reactions in Fig. 1 between DNA binding and the manifestation of the tumor. This process has been reviewed $[88,249]$, and section 6.1 summarizes the various possibilities for an interference of chemicals with the process of tumor promotion.

In addition to the carcinogenicity by organic chemicals, there are other causes of cancer; carcinogenic metals, other inorganic carcinogens, any form of radiation, the influence of oncogenic viruses. None of these topics will be discussed in this review.

\subsection{Short-term tests for the detection of chemical carcinogens. Quantitative carcinogenesis}

Most short-term tests for carcinogenicity measure one of the steps shown in Fig. 1. These are, among others, reaction with nucleic acids or proteins, DNArepair synthesis, mutagenesis, various chromosome damages, cytological alterations, in vitro cell transformation, teratogenesis, or accelerated tumor formation. They have been reviewed before $[19,77,94,180,258]$ and have also been compared with each other [214]. Many of these systems do not deal with intact mammalian organisms but use bacteria or cells in culture. The wellknown "Ames test", e.g., is based upon the measurement of backmutations of Salmonella of selected strains after incubation with the test compound [2]. The metabolic activation is performed by microsomes of mammalian organs together with cofactors. This is necessary because of the very limited ability of Salmonella for drug metabolism.

The Ames test is able to recognize qualitatively about $90 \%$ of the known carcinogens as mutagens. Among the $10 \%$ false negatives are some very potent carcinogens of the dimethylamino and hydrazine type as well as a number of halogenated compounds. The reason for their ineffectiveness has been discussed [ 3 , 66,173 ], and it has emerged that the metabolic activation in the bacterial incubation is insufficient for $\mathrm{N}$-demethylations or dehalogenations. By varying the experimental conditions a slight improvement has been achieved but it still seems that, for the above-mentioned chemical classes, the Ames test is not the appropriate short-term test.

Another point of concern is the lack of the quantitative aspect in the interpretation of the Ames test and of other in vitro tests. A discussion about a quantification of carcinogenicity of chemicals [175] is now developing although it should have been obvious for a long time that some carcinogens are more potent than others. From long-term bioassays it can easily be calculated that the range of carcinogenic potency spans about 6 orders of magnitude if we compare the dose per $\mathrm{kg}$ animal and day which is needed to induce a specific tumor in $50 \%$ of the animals within their life span. This dose ranges from less than one microgram $/ \mathrm{kg} \cdot$ day for aflatoxin $B_{1}$ to many grams for saccharin.

A look at the mutagenicity data from the Ames test shows that this quantitative aspect can barely be considered even within a class of related compounds. The polycyclic hydrocarbons, e.g., which can be well studied in the Ames test, show increasing mutagenicity in the order of dibenz $[a, h]$ anthracene $<7,12$-dimethylbenz $[a]$ anthracene $<3$-methylcholanthrene $<$ benzo $[a]$ pyrene $<$ dibenz $[a, c]$ anthracene [172] although their effect on mouse-skin 
tumor formation increases in the following order: dibenz $[a, c]$ anthracene $<$ dibenz $[a, h]$ anthracene $<$ benzo $[a]$ pyrene $<3$-methylcholanthrene $<7,12$-dimethylbenz $[a]$ anthracene [98].

These problems of incomplete metabolic activation and lack of quantitative correlation have been discussed here with respect to the Ames test only, but this could also have been done with many other in vitro systems. This is the reason why we have chosen an intact mammalian organism as the experimental basis for another possible short-term experiment, the covalent binding of chemicals to biological macromolecules. This test detected a number of Amesnegative carcinogens and provides a basis for a quantitative assessment of carcinogenic potency if DNA is taken as target.

\subsection{Covalent binding of chemical carcinogens to biological macromolecules}

The first experiment on in vivo binding of a chemical to a biological macromolecule was reported by the Millers in 1947 with 4-dimethylaminoazobenzene in rat liver [177]. Since then, more than 150 compounds have been shown to undergo a covalent binding to biological macromolecules in vivo or in vitro and a number of reviews are available: a recent and very extensive one by Lawley [139], others by Irving [103], Sarma [228] and, for $N$-nitroso compounds only, by Lijinsky [149]. Brookes has published two classical short reviews [22, 24] and a short discussion on the importance of DNA as the most critical target for a covalent binding [25].

The easiest way to study the reactivity of a chemical with a biological macromolecule involves an in vitro incubation of radiolabelled chemical with protein in the presence of some activating enzyme preparation [274]. In vivo, the binding is not so easily detected because the high in vitro concentrations cannot be achieved.

Protein binding is in most cases higher than binding to nucleic acids because of the higher intracellular concentrations of protein and their closeness to the site of activation. In addition, the sulphur-containing amino acids are very good nucleophiles and, therefore, very good trapping agents for the electrophilic ultimate carcinogens. Unfortunately, protein binding does not give any quantitative answer to the carcinogenicity of a chemical but it shows at least that a reactive metabolite can be formed. This will always be a warning sign because, in principle, the binding to DNA could have occurred but the limit of detection was perhaps not low enough.

Some target atoms on the nucleic acid and proteins are shown in Fig. 3. These include all the more or less nucleophilic centers in nucleotides and amino acids. The chemical reactivity of these biological targets has been discussed before $[135,202,244,245]$ and the biological significance of the binding of a carcinogen to one or the other nucleophilic center will be discussed in chapter 4.

In the last section it has been pointed out that the metabolic activation in most in vitro short-term tests is different from the in vivo situation so that false-negative results are obtained with some important classes of carcinogens. The positive results that were obtained in a covalent binding assay in vivo with most of these false-negatives make it worthwhile to thoroughly evaluate this interaction as a possible carcinogenicity test. 


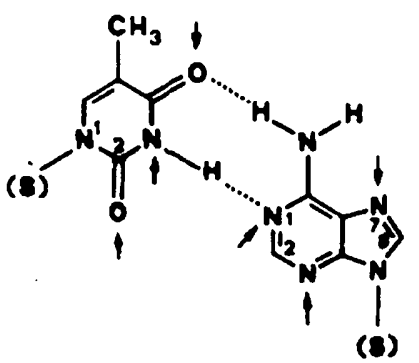

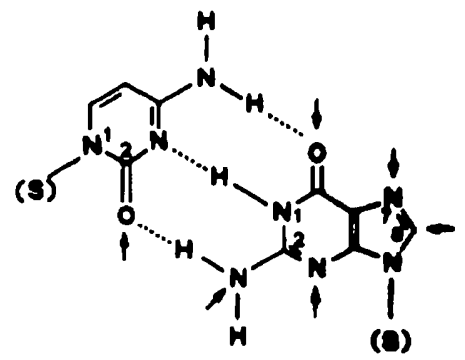

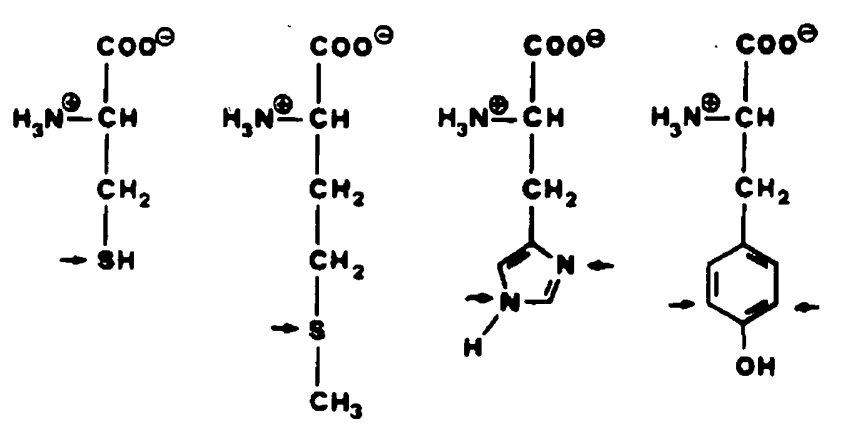

Fig. 3. Nucleophilic atoms of components of biological macromolecules. The most reactive (not necessarily most critical) target atoms of DNA and protein are indicated with an arrow. Analogous for RNA. Top, thymine-adenine; cytosine-guanine. Bottom, cysteine (also as cystine), methionine, histidine, tyrosine. Not shown, DNA phosphate.

\section{Covalent binding to DNA}

\subsection{Introduction. In vivo versus in vitro}

The first experiment on in vivo DNA binding dates back to 1957 when Wheeler and Skipper measured the reaction of C-14-methyl-labelled nitrogen mustard with various DNAs of mice and rats [284]. In 1964 Brookes and Lawley showed that carcinogenicity for mouse skin of a number of polycyclic hydrocarbons correlates with covalent binding to skin DNA but not to skin protein [21]. Similar findings of a correlation of carcinogenic response to DNA binding but not to protein binding were reported for derivatives of 4-dimethylaminoazobenzene [31], for $N$-hydroxy-2-acetylaminofluorene after different pretreatments [169] and for $o$-aminoazotoluene after chronic administration [140].

Since 1964, a variety of carcinogens have been studied for their effectiveness of binding to DNA in vivo and today, this list comprises of more than 80 chemicals of many different classes of carcinogens (see sections 3.1 and 3.2). It includes a number of compounds which are barely detectable in the Ames test [172]: dimethylnitrosamine (Table 18), methylazoxymethanol (Table 17), 4-dimethylaminoazobenzene (Table 16), 1,2-dimethylhydrazine (Table 17), safrol (Table 19), carbon tetrachloride (Table 13), urethane (Table 20) and ethionine (Table 20) [see Tables for refs.]. It therefore seems that DNA binding in intact mammalian organisms recognizes more carcinogens than any in vitro assay and that the result can, in addition, be interpreted in a quantitative way. 
Unfortunately, the amount of chemical bound to DNA in vivo is very small and can hardly be detected by purely chemical means. Radioactive tracers (mostly C-14, H-3, or S-35) must therefore be used in such studies. This is the main limitation of the assay, restricting it to single compounds which are available in radiolabelled form commercially or by radiosynthesis.

Most of the DNA-binding assays performed in the last 15 years aimed at the elucidation of the molecular basis of chemical carcinogenesis. The assay was not used for carcinogenicity testing, probably because its potential value was not clear with the small number of compounds investigated at that time. The results were also interpreted very much like those of other short-term tests and the quantitative potency aspect of chemical carcinogens was established only within classes of related compounds.

One attempt in this direction was undertaken in Brookes' laboratory [58]. They measured the binding of polycyclic hydrocarbons to DNA of mouseembryo cells in culture and established a Binding Index as DNA damage divided by the dose incubated. The group of hydrocarbons with a high binding index consisted of potent carcinogens while the other group consisting of non-carcinogens and dibenz $[a, h]$ anthracene had much lower values.

This quantitative approach was not really expanded from the in vitro experiments to the in vivo situation, although many studies have shown that the measurement of a binding of a chemical to DNA is related to the carcinogenic response only if the experiment is carried out in vivo.

With 4-dimethylaminoazobenzene, e.g., it was shown that binding to rat-liver DNA and tumor formation decreased after pretreatment with phenobarbital [53], while the ability of liver microsomes to form DNA-bound metabolites even increased after phenobarbital pretreatment [52]. Similar results were obtained with aflatoxin $B_{1}$ where pretreatment with phenobarbital reduces hepatocarcinogenicity and DNA binding in liver in vivo [72], whereas in vitro results using microsomes from phenobarbital-pretreated rats show an efficient production of the ultimate carcinogen compared with control rats [70].

Despite this clearly higher relevance of in vivo studies, the cost of the radioactive chemicals might require, in some cases, the study of an interaction with DNA under in vitro conditions, where the local concentrations of chemical and DNA can be chosen much higher than is possible in an intact mammalian organism.

We have, therefore, performed a number of in vitro experiments on the binding of a standard carcinogen, benzo[a]pyrene (BP), to DNA in order to see what sensitivity could be gained in the detection of a DNA binding in a model system [106]. Liver perfusion in situ, liver single cells, liver homogenate, liver microsomes incubated with DNA were used, as well as fibroblasts from a rat granuloma pouch and two cell lines. It was found that the specific activities of the DNA differed by a factor of as much as 1600 between the in vivo experiment (rat-liver DNA) and the microsomal incubation of DNA with BP. Fortunately, the yield of DNA from the in vivo experiment is very high, so that the limit of detection of a binding in the two systems differs only by a factor of about 30 . We consider this difference small if the relevance of the findings are compared.

In addition, it was found that liver single cells gave rise to a DNA with a rela- 
tively high specific activity, and a limit of detection of a binding only 5 times greater than the system with the microsomes. Primary liver single cells could therefore provide a useful tool for the study of DNA binding if an in vivo experiment is too expensive but when a total loss of quantitative relevance, as with microsomal incubation, is to be avoided.

\subsection{The in vivo "Covalent Binding Index": $C B I$}

The promising quantitative correlation of DNA binding in vivo with the carcinogenic response prompted us to expand Brookes' in vitro Binding Index to the in vivo situation, and examine a number of controversial compounds in intact mammalian organisms.

For a comparison of different compounds, eventually studied in different laboratories and under various experimental conditions, the binding to DNA must be expressed per unit dose, such as

$$
\text { CBI }=\frac{\text { damage to DNA }}{\text { dose }}
$$

In agreement with earlier definitions of DNA damage, the following units were chosen:

$\mathrm{CBI}=\frac{\text { micromole chemical bound per mole nucleotides }}{\text { millimole chemical administered per kg animal }}$

These molar units allow a very rapid visualization of how many molecules are bound per million nucleotides after a theoretical dose of $1 \mathrm{mmole} / \mathrm{kg}$. The actual dose or exposure of an animal or human to a carcinogen must always be accounted for, if the number of DNA adducts has to be estimated for a given dose. A multiplication of the CBI with the dose would be appropriate only in the case of linear dose-binding relationships. An estimation of the actual DNA damage is a prerequisite for a risk assessment and it is clear that for two compounds with similar CBI, e.g. benzene and ethinylestradiol (1.7 and 1.5 for ratliver DNA resp.), it is very important to include all available knowledge on the actual daily dose for the humans exposed.

The CBI unit chosen above is not very convenient for the actual experiment because the amount of chemical is normally not represented in molar units but by its radioactivity (i.e. in Curies or dpm), and the amount of DNA is usually expressed in weight units, i.e. in milligrams. Since 1 mole nucleotides represents, on average, $309 \mathrm{~g}$ DNA, a CBI prime, CBI', could be defined as

$$
\mathrm{CBI}^{\prime}=\frac{\mathrm{dpm} \text { chemical bound per mg DNA }}{\mathrm{dpm} \text { chemical administered per kg animal }}
$$

The experimental data can be processed easily with this formula, and then be converted to the molar units according to

$$
\mathrm{CBI}=\frac{\mathrm{CBI}^{\prime}}{3.24 \cdot 10^{-9}}
$$


A DNA-binding assay involves the following steps: (1) The administration of the radioactive chemical to the animal. (2) A waiting time of a few hours. (3) Isolation of DNA from relevant organs. (4) Liquid-scintillation counting of the DNA or DNA-carcinogen adducts isolated.

It is obvious from the formula of the $\mathrm{CBI}^{\prime}$ that the limit of detection of a binding is dependent on (1) The total radioactivity administered. (2) The amount of DNA in the scintillation vial. (3) The counting efficiency of the label used. (4) The net radioactivity in the DNA-containing scintillation vial which can be considered significant.

The yield of DNA from an organ and the counting efficiency can be estimated before the experiment is performed. The total radioactivity available is known as well, and the lowest significant radioactivity in a scintillation vial depends upon the purity of DNA and the rigorous exclusion of all contaminating radioactivities. In our hands, we can detect significantly as little as $2 \mathrm{cpm}$ [158].

The limit of detection can now be calculated if the formula for the $\mathrm{CBI}^{\prime}$ is rearranged to read

$\mathrm{CBI}^{\prime}$ minimal $=\frac{\frac{\text { significant cpm }}{\text { counting efficiency }}}{\text { total dpm administered }} \times \frac{\mathrm{kg} \text { body weight }}{\text { yield of DNA from organ }(\mathrm{mg})}$

For example, we have $100 \mu$ Curie C-14 labelled chemical available and would like to measure the binding to rat-liver DNA. Per $\mathrm{kg}$ rat there are about $40 \mathrm{~g}$ liver with a yield, in our hands, of about $60 \mathrm{mg}$ DNA. If we enter the above formula with these data, taking $2 \mathrm{cpm}$ as a significant radioactivity and a counting efficiency of $80 \%$, the equation is now

$\mathrm{CBI}^{\prime} \min ($ limit of detection $)=\frac{2.5}{2.22 \cdot 10^{8}} \times \frac{1}{60}=1.9 \cdot 10^{-10}$ or $\mathrm{CBI} \min =0.06$

It can be seen from these equations that the size of the animal does not have a direct influence on the limit of detection of DNA binding if it is approximated that the weight of an organ (and of its amount of DNA) is proportional to the total weight of the animal. This theory has its limitation on the experimental side because it should be impossible to measure the radioactivity on the total amount of an elephant's liver DNA in one scintillation vial.

\subsection{Choice of experimental conditions for the measurement of a $C B I$}

The suggestions made in the next sections have been followed in our own recent experiments. The CBI calculated from the literature data and compiled in the Tables $13-20$ are based on experiments which do not always conform to these standards.

\subsubsection{Position of the radioactive label}

For a DNA-binding assay in vivo a radiolabel is a prerequisite except for the very rare carcinogens with extremely high Binding Indices, like some $N$-nitroso- 
compounds (Table 18) or aflatoxin $B_{1}$ [131]. Since the radioactivity on the DNA is the measure for bound chemical it is obvious that a binding can only be detected if the portion of the compound which is bound to the DNA still carries the label. It is therefore important to evaluate the pharmacokinetic data available in order to assess the probability for a certain part of the molecule to become an alkylating moiety [75]. Since a great deal is already known about the metabolic activation of all classes of carcinogens, it is in most cases possible to predict whether a given radioactive label will stay in the binding portion of the molecule or not.

This fact that only a part of the molecule might be bound to the DNA was, in some cases, used for the elucidation of the metabolic steps and eventual cleavage of the molecule in the generation of the ultimate carcinogen. With 4-dimethylaminoazobenzene, tritiated in the amino ring and C-14 labelled in the prime ring, it was shown that both benzene rings are bound together to DNA [55]. Such mixed-label studies with urethane suggested that only the ethyl group is bound to rat nucleic acids [213], whereas in mice, the carboxyl carbon also seems to be attached [18,143]. Additional experiments with ethoxy. 0-18 label in mice did not, however, give rise to an O-18 isotope enrichment on the DNA [208]. Therefore, there is still no agreement about the alkylating moiety of urethane. Such problems can arise from compounds with barely known or complicated patterns of metabolites, especially where a relatively small fraction of the total number of metabolites is responsible for all DNA binding.

Another point which must be considered is that most chemicals have a number of different routes of oxidation and degradation, some of which might lead to the loss of the label which could then be incorporated biosynthetically into DNA. Most commonly, with tritiated compounds labelled at a number of positions some tritium is always lost, either by exchange or by oxidative processes. The tritiated water formed can then be incorporated into the nucleotides. This is most easily done via the reduction of ribose to 2-deoxyribose where a proton, or in this case a tritium ion from the water pool replaces the 2-hydroxy group.

With tritiated compounds there is therefore always the danger that the label is incorporated into DNA in a stable form and cannot be distinguished from covalently bound chemical without degradation of the DNA. Appropriate control experiments are described in section 2.4.3.

As opposed to this drawback of general tritium labelling these compounds have the advantage that the DNA-bound molecule still carries most, if not all (benzo $[a]$ pyrene [196]) of the label so that a binding cannot be missed.

\subsubsection{Dose and dose schedule}

In general pharmacology it is an accepted fact that the kinetics of absorption, distribution, and metabolism are greatly influenced by the dose. From a small dose of vinyl chloride, for example, almost $100 \%$ is metabolized. With higher doses, however, the amount metabolized does not increase proportionally [89], but an increasing fraction is expired [81]. This happens because of a saturation of the oxidation pathway which is also responsible for the activation of vinyl chloride to a chemically reactive metabolite [10]. In this critical range, 
the doubling of the dose does not, therefore, lead to the doubling of the formation of reactive metabolites so that covalent binding to macromolecules and carcinogenic response does not increase linearly with the dose either.

Such fundamental theories on saturation processes seem to be forgotten when long-term bioassays are planned and interpreted. These assays are normally performed with extremely high oral dosage. This is necessary in order to get a significant yield of tumors with a small number of animals. The results might be misleading because an extrapolation of such a finding to lower doses cannot be based upon any mathematical model without knowledge of the dosedependent profile of metabolites. In addition, it is known that the enzymatic activity induced by a high dose of a polycyclic hydrocarbon can alter the relative amounts of the different metabolites and, with this, alter the amount of DNA adducts formed $[159,277]$.

For a DNA-binding assay it would therefore be appropriate to use a dose which is in the same order of magnitude as that of human exposure. In most cases, however, this will not be feasible because the specific radioactivity is not high enough and a satisfactory limit of detection could not be reached with the total radioactivity administered with a low dose. In any event, it is in most cases unwise to dilute the radioactive sample with inactive chemical, and the dose should be so low that the binding to DNA can just significantly be measured.

Obviously, the determination of a dose-DNA-binding relationship would answer the question of a non-linearity and this has indeed been done in a number of cases. The results will be discussed in section 5.4.1.

Exposure of humans to environmental carcinogens lasts a whole lifetime. It would thert.ure be interesting to pretreat the animals with the compound to be tested. This can be very costly if radioactive material is used for the full period of treatment. The rare experiments where this has been done are discussed in section 5.4.2. The results are interesting with respect to the mechanism of carcinogenic action but they do not improve the prediction of the carcinogenic potency of a chemical because of the high cumulative dose obtained with such schedules.

\subsubsection{Solvent and route of administration}

The solvent used for the administration should be chemically and pharmacologically inert. An aqueous solution is appropriate for water-soluble compounds. For lipophilic chemicals, the carrier should not interfere with the bioavailability of the compound tested and it should be processed by different metabolic routes and enzymes or should be completely undegradable. This could therefore be a methylcellulose solution, a solution in dilute alcohol or a solution in oil. Dimethylsulphoxide should be avoided since it has been shown to form macromolecular complexes with many types of chemicals [105] and to protect rat-liver DNA from strand breaks by dimethylnitrosamine but not by methylnitrosourea [252] probably by interfering with the oxidative demethylation reaction.

The route of administration of volatile compounds is preferably by inhalation. Inhalation experiments are often complicated by the fact that a part of the dose can be lost by expiration after stopping the exposure. It is therefore 
difficult to determine the exact dose administered and calculate a CBI. We have developed a closed inhalation chamber (Fig. 4) [156] where a small laboratory animal can be kept in the same atmosphere for up to $24 \mathrm{~h}$. The only gas exchange is the adsorption of the expired carbon dioxide on soda lime and an equimolar replacement with oxygen. The disappearance of the chemical investigated from the atmosphere can be followed by air sampling and gas-chromatographic analysis. Such a system allows for a complete metabolism of a given amount of chemical and was used in the study of the binding properties of benzene [157] and toluene. A similar all-glass system without automatic oxygen supply was described before and used for the study of vinyl chloride [8].

If, for any reason, an inhalation experiment cannot be performed, intravenous (i.v.) or subcutaneous (s.c.) administration is probably the most similar route if local effects on the respiratory system are not to be assessed. As a vehicle for i.v. injections of lipophilic compounds we have successfully taken serum of syngeneic animals which has reasonable solubilizing properties thanks to lipophilic protein binding sites [277].

Oral intake is a very common route of exposure to environmental carcinogens. One might therefore tend to think that this is also the appropriate route of administration in a binding assay with laboratory rodents. One should, in this connection, not forget that eating habits, intestinal anatomy and $\mathrm{pH}$, intestinal flora and basal metabolism are different in rodents and humans. These differences could have a substantial influence on intestinal metabolism, bioavailability and absorption and, as a consequence, also on DNA binding.

The pig is an animal species which is very close to the human with respect to such dietary functions. We were interested to compare DNA binding in this species with that in the rat and have performed an assay with orally administered aflatoxin $B_{1}$. The CBI for liver was about 5 times higher in the pig than in the rat (Table 19) but it is possible that other parameters than the intestinal functions have contributed to this difference (see chapters 5 and 6 ).

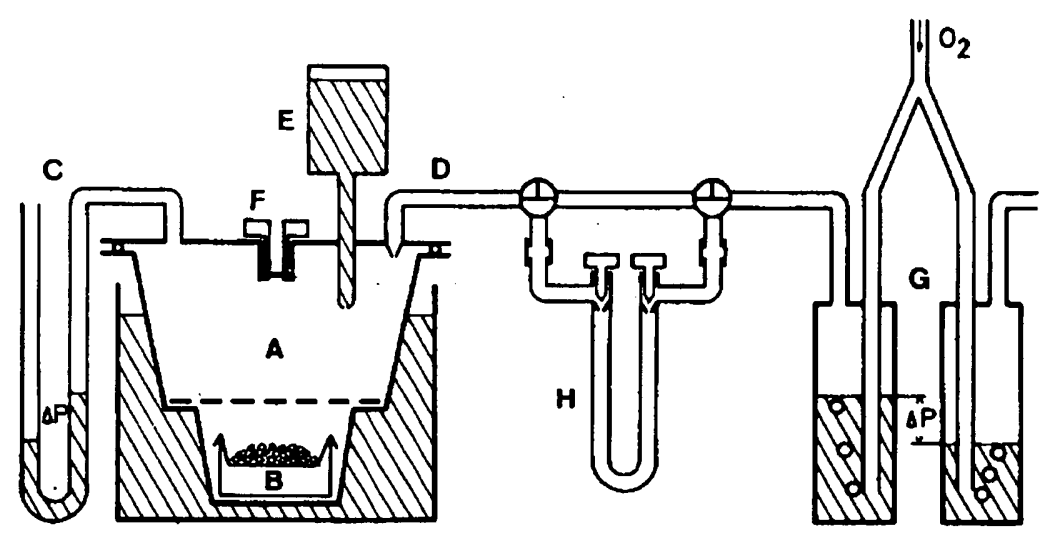

Fig. 4. Schematic view of a closed inhalation system. A, regular glass desiccator as chamber. B, soda lime for the adsorption of carbon dioxide. C, U-type manometer, filled with water. $D$, oxygen inlet. $E$, water bottle (or thermometer). F, holder for a rubber septum for air sampling with needle and syringe. G, oxygen supply system. With this arrangement of gas washing bottles a slight and constant underpressure. $(\Delta P)$, given by the difference in the water levels, can be maintained in the chamber. This allows for a continuous control whether the chamber is air-tight. Only when the pressure decreases below that value does oxygen bubble through the left bottle into the chamber and restores the desired underpressure. H, glass U-tube with teflon valves for trapping volatile radiochemicals in liquid nitrogen from break-seal ampoules with subsequent transfer into the chamber in the oxygen flow. 
A number of compounds have been tested for DNA binding after different routes of administration. These examples are easily found in Tables 13-20 while here it is sufficient to summarize that there is no great difference in the Binding Index for liver DNA after intravenous, intraperitoneal or subcutaneous injection. An oral administration reduces the binding index by a factor of 5-10 with the polycyclic aromatic hydrocarbons, but has only a slight reducing influence on $N$-nitroso compounds or aflatoxin $B_{1}$. For organs other than the liver, this influence might be different, especially if one takes into account the strong local effects of some carcinogens that do not need metabolic activation, or first-pass effects for carcinogens which are rapidly metabolized in the liver after oral or intraperitoneal administration.

The intraperitoneal administration is somewhat artificial, but it is easy experimentally and it mimics an oral administration because most of the blood vessels of the peritoneal cavity empty into the portal vein. A DNA-binding assay for liver would therefore yield a theoretical binding potency expected for complete absorption of a chemical unchanged by gastro-intestinal processes.

\subsubsection{Time between administration and sacrifice}

The amount of chemical bound to DNA rises steeply in the first minutes and hours, levels-off, and decreases slowly thereafter according to the chemical stability of the adduct, enzymatic excision of the damaged DNA, and cell death. The binding should optimally be measured at its maximum level. This can be in an hour or less after intravenous administration of a low dose of an alkylating agent which does not need enzymatic activation (methylnitrosourea) [201]. It can, on the other hand, take $20 \mathrm{~h}$ to reach the maximal level of DNA binding after intraperitoneal administration in oil of a very high dose of a lipophilic compounds which needs enzymatic activation (2-methyl-4-dimethylaminoazobenzene, $150 \mathrm{mg} / \mathrm{kg}, 10 \mathrm{ml}$ oil $/ \mathrm{kg}$ ) [279]. The time needed to reach maximum binding is therefore dependent on the time that it takes for the chemical to diffuse or be transported from the site of administration into the target organ, to the activating enzymes and finally to the DNA. 3-6 h seem reasonable for intravenous, $6-12 \mathrm{~h}$ for intraperitoneal or oral administrations of small doses of slightly water-soluble chemicals. The shorter this period of time, the smaller is the extent of incorporation of radioactive fragments by biosynthetic routes (section 2.4.3).

A time dependence of the binding could of course be determined. This has indeed been done with many carcinogens (see Tables 13-20) in order to gain some insight into the DNA-repair processes and the results are discussed in section 4.3.2. To summarize at this point, it was shown that the persistence of DNA-bound chemical reflects a certain refractoriness to DNA repair which is an important modulator of the carcinogenic consequences of DNA binding.

It would therefore be very valuable to measure DNA binding at two points in time, the first around the maximum level of binding as discussed above, and the second at about one week after the administration. For the later point in time it will, however, be necessary in many cases, to degrade the DNA and make sure that the radioactivity measured is really due to an adduct and is not a result of biosynthetic incorporation of the label. In addition, the following two points must be considered: (i) The chemical stability of the adduct: for 
example, alkylation of guanine at nitrogen-7, leads to a positive charge which renders the nucleoside relatively unstable. A depurination is the obvious consequence with a loss of the base. This reaction occurs in vivo as well as during the isolation of DNA and might simulate a repair activity. (ii) Cell death might occur when the alkylation damage does not permit the survival of the cell. A degradation of the cellular constituents of such dead cells mimics a time-dependent removal of DNA-bound label which at first sight cannot be separated from real repair processes and might also show non-linear repair activity with the dose of the carcinogen. If enzymatic repair processes are to be followed, it will therefore be necessary to compare the rates of removal of various DNA-bound adducts.

\subsubsection{Isolation of DNA. Liquid-scintillation counting}

Since the limit of detection of a binding is directly related to the yield of DNA it is obvious that large or DNA-rich organs are most attractive. This is one reason why liver is examined in most cases, the second reason being that liver contains all the enzymes necessary for the activation of all known carcinogens. It is therefore not surprising that the very early studies on DNA binding were done with hepatocarcinogens and liver DNA. Liver DNA was examined also with compounds that do not give rise to liver tumors and it was surprising to see that CBI for liver give, nevertheless, quantitative results on the carcinogenic potency of compounds that induce tumors in organs other than the liver (see section 4.2).

Within a specific organ there are various types of cells that can differ substantially from each other with respect to their drug-metabolizing capacities. Thus, if a CBI for testis is determined, this represents an average and it is dangerous to stress too much the quantitative aspect of a DNA binding assay for organs with a large number of different cell types.

Several methods are available for the isolation of DNA. We use, after a phenol:chloroform extraction, a hydroxyapatite adsorption chromatography which can be performed with large amounts of DNA but does not allow the highest yield. After dialysis and precipitation with ethanol the DNA is redissolved in phosphate buffer and the radioactivity is counted after the addition of scintillation cocktail [277].

It was shown in the original report by Markov and Ivanov [166] that this procedure yields a DNA with maximum contaminations of $1 \%$ RNA and less than $1 \%$ protein. The determination of this low level of protein was performed with a radioactive precursor, ${ }^{35} S$-methionine, and a determination of the specific activity of chromatin protein, a probable DNA contaminant. With this experimental set-up we determined $0.5 \%$ protein on the DNA isolated from rat liver. An additional, but less sensitive criterion for protein contaminations is the UV absorbance ratio $A 260 \mathrm{~nm} / A 230 \mathrm{~nm}$. Nucleic acids have a maximum around $260 \mathrm{~nm}$ and a minimum around $230 \mathrm{~nm}$, protein has a minimum near $255 \mathrm{~nm}$ and a strong side absorption from the amide bond at $230 \mathrm{~nm}$. All our DNA samples exhibit an absorbance ratio of better than 2.3 , which is as good as those published in the original report [166].

In order for this low amount of protein to have a marked influence on the total radioactivity of the DNA sample, the Specific activity of the protein 
would have to be orders of magnitude above that of the DNA. A difference of a factor of two hundred would result in equal contributions of the DNA and the $0.5 \%$ protein to the total radioactivity measured. This would then be responsible for an error of a factor of two for the Covalent Binding Index, CBI. It will be seen in chapter 4 that even such a remarkable error would not have a great influence on the classification of the chemicals into the classes of strong, moderate, or weak carcinogens because the total range of CBI covers more than 6 orders of magnitude.

Simultaneous determination of protein and DNA binding has been reported for many carcinogens, and factors of up to one hundred have been shown [37, $97,280]$. In most cases, however, the specific activity of cytoplasmic protein is less than 10 times higher than that of DNA. This range was determined with mustards [23], polycyclic aromatic hydrocarbons [21], azo derivatives of aromatic amines $[31,140,141]$, and a number of $N$-nitroso compounds [149], i.e., with representatives of many possible classes of carcinogens. On the other hand, with aflatoxin $B_{1}$, rat-liver DNA reaches a higher specific activity than cytoplasmic protein $[71,265]$. In addition, it is to be noted that in most cases these specific activities were determined with phenol-extractable protein which is not a likely contaminant of DNA. The nuclear proteins isolated in one of the studies had only about a third of the specific activity of the cytoplasmic protein [97].

A contamination of the DNA with RNA is not critical either, because the nucleophilic centers of these macromolecules are almost identical and only the local concentration of ultimate carcinogen determines the ratio of DNAversus RNA-adduct formation. The specific activities of DNA and RNA always ranged within one order of magnitude so that a $1 \%$ contamination of DNA with RNA cannot distort the binding data by more than $10 \%$.

Probably a more important problem with the purification of the DNA is the avoidance of any radioactive contamination. It should be borne in mind that a DNA-binding experiment starts with milliCurie amounts of radioactivity and only a few cpm on the DNA have to be measured in the end. In our laboratory, we therefore have a strict separation of glassware, disposable pipettes, siphons, scintillation cocktails, refrigerators and freezers used for the isolation steps after the hydroxyapatite column. Each person involved in the isolation of DNA has his personal glassware of these critical steps and only fresh, precounted, low background glass scintillation vials should be used.

\subsection{Control experiments}

The control experiments discussed in this section are necessary if the DNA adducts are not positively identified by chromatography of the nucleosides and adducts after enzymatic breakdown of the DNA [126,207, and refs. therein]. Such a proof of adduct formation will always be required if the biosynthetic incorporation of radioactivity into normal nucleosides cannot be properly taken into account (section 2.4.3). The further handling and processing of DNA for these determinations obviously impairs the limit of detection of a binding because of the inevitable additional loss of material and, more severely, because some adducts are resistant to complete hydrolysis. This was shown with a number of polycyclic hydrocarbons [196,207], where a considerable 
fraction of the reaction products with DNA did not show up with the adduct peaks of a Sephadex LH2O chromatogram but was heading the unmodified nucleosides.

\subsubsection{Background radioactivity}

Background radioactivity is always determined from a DNA sample isolated from a control animal which is administered unlabelled chemical. The gross radioactivity of these samples can be held within less than $1 \mathrm{cpm}$ as one standard deviation if the precautions mentioned in the last paragraph are observed.

\subsubsection{Intercalation. Tritium exchange}

The measurement of radioactivity on the DNA sample does not tell us right away whether the compound is bound covalently or whether it is merely intercalated and bound physico-chemically and was not removed from the DNA during the isolation procedure. In order to determine this non-enzymatic binding, we regularly incubate radio-labelled chemical with the total homogenate of a control liver in the denaturing medium used as the first step for the isolation of DNA. It is assumed that under such conditions $(8 \mathrm{M}$ urea, $1 \%$ sodium dodecyl sulphate, $10 \mathrm{mM}$ EDTA in sodium phosphate buffer) a metabolic activation of the test compound to a reactive derivative does not occur. This incubation, of course, cannot be done with directly alkylating compounds. The incubation must be carried out in the dark and under nitrogen in order to exclude photooxidative reactions which might also lead to covalently bound chemical. After $0.5 \mathrm{~h}$ of gentle shaking at $37^{\circ} \mathrm{C}, \mathrm{DNA}$ is isolated from that liver homogenate by the regular purification procedure, and the radioactivity on that DNA tells us whether our isolation method has freed the DNA from intercalated chemical, and whether exchanged tritium atoms have also been removed.

So far, the radioactivity associated with DNA after this incubation has never exceeded $0.6 \%$ of that from the actual experiment if the specific activity of the liver homogenate of the control experiment was equal to that of the liver of the treated animals at the time of sacrifice. This maximum value was found with 7,12-dimethylbenz $[a]$ anthracene under conditions where a photo-oxidation reaction could well have taken place $(20 \mathrm{~h}$ under air and normal light). It is known from this and related compounds (benzo[ $a]$ pyrene) that non-enzymatic covalent binding does take place [83].

\subsubsection{Biosynthetic incorporation of radioactivity}

As was mentioned in section 2.3.1, biosynthetic incorporation of radioactivity into DNA can occur if a spontaneous or enzymatic degradation of the labelled compound releases the radioactive label as a small molecule.

Tritiated compounds almost inevitably lead to the formation of tritiated water of which a tritium ion can quite efficiently be incorporated into newly synthesized DNA. In order to account for this incorporation the specific activity of the body water must be known and a comparison with control experiments with tritiated water will provide an estimate on that part of the radioactivity of DNA that is due to tritiated water.

Such control experiments were performed with oral doses of about $10 \mathrm{mCi}$ tritiated water per $\mathrm{kg}$ rat, and liver DNA was isolated after 12,24 and $48 \mathrm{~h}$. 
Fig. 5 shows the results for adolescent and adult animals. The incorporation of radioactivity into DNA increased linearly with time, thus indicating a biosynthetic mode of incorporation and reflecting the fact that the half-life of tritium in the tritiated water pool of the animal is larger than our period of observation. No difference is seen between the age groups which means that the rate of DNA synthesis in liver does not differ significantly. The low CBI values obtained from these experiments show that this incorporation is not very critical for liver DNA (about $21 \mathrm{dpm} / \mathrm{mg}, 12 \mathrm{~h}$ after an oral dose of $10 \mathrm{mCi} / \mathrm{kg}$ ). The tritium radioactivity measured on the DNA of these control experiments represents stable incorporation into non-exchangeable positions as can be deduced from the control incubation described in the legend to Fig. 5.

If the CBI for tritiated water given in Fig. 5 are taken as the basis for a calculation, one important aspect should not be overlooked: the fact that an oral dose of tritiated water yields a uniform distribution of radioactivity in the total body water whereas an enzymatic formation of tritiated water occurs intracellularly only and gives rise to higher local specific activities initially, with a probably higher chance of an incorporation of tritium into DNA. This was indeed found with a comparison of the Binding Indices of tritiated versus C-14 labelled benzene [157]. The CBI for liver DNA from C-14 labelled benzene amounted to 1.7 (Table 14), whereas the tritiated compound gave rise to an apparent CBI of 2.4 , probably because of the additional radioactivity incorporated from the tritiated water formed.

The specific activity of tritiated body water was determined from a small diluted aliquot of the urine collected at the time of sacrifice. This turned out to be about $20 \mu \mathrm{Ci} / \mathrm{ml}$ urine. Under the reasonable assumption that the specific activity of urine is equal to that of the total body water, this specific activity corresponds to a dose of about $16 \mathrm{mCi} / \mathrm{kg}$ rat which would have contributed about $26 \mathrm{dpm} / \mathrm{mg}$ liver DNA according to our control experiments. In the

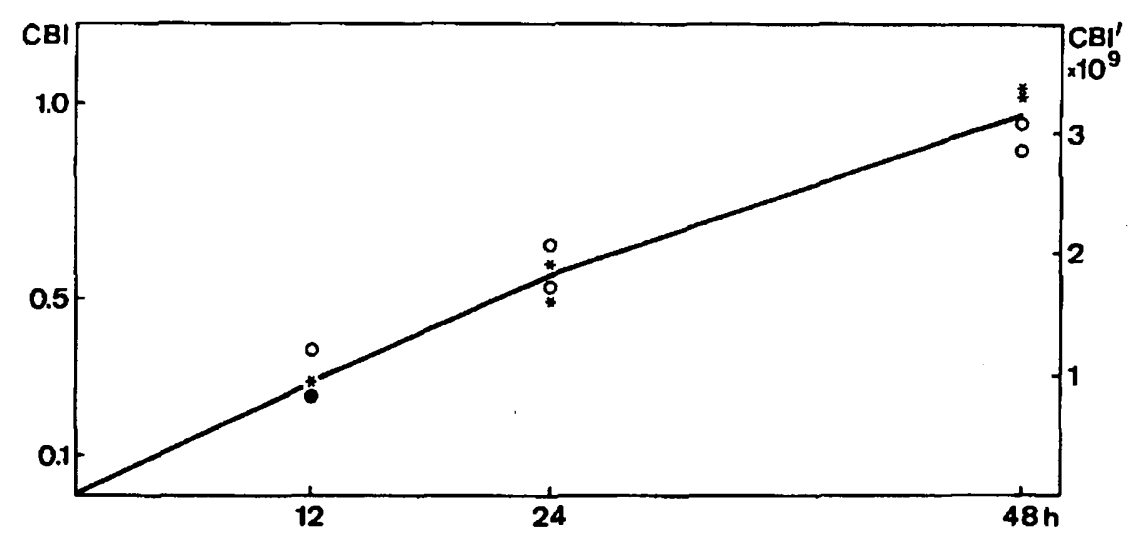

Fig. 5. Time course of the incorporation of tritium from tritiated water (HTO) into rat-liver DNA. Young $(0,108-124 \mathrm{~g})$ and adult $(*, 282-307 \mathrm{~g})$ male rats (SIV-50, Sprague-Dawley-derived) were given by gavage about $10 \mathrm{mCi}$ HTO per $\mathrm{kg}$ body weight. At the time indicated, DNA from liver was isolated and counted by liquid scintillation $(20-80 \mathrm{dpm} / \mathrm{mg})$. The incorporation is shown as a fraction of the dose, on the left hand side in CBI units of micromole tritium/mole nucleotides per mmole HTO/kg body weight, on the right hand scale in CBI' units of $\mathrm{dpm} / \mathrm{mg}$ DNA per $\mathrm{dpm} / \mathrm{kg}$ (see section 2.2 for more information on these units). CBI mean and standard deviation from the 4 animals at each time point are $0.29 \pm 0.06$ (12 h), $0.56 \pm 0.07(24 \mathrm{~h}), 0.97 \pm 0.07(48 \mathrm{~h})$. Control experiment (section 2.4.3), incubation of $50 \mathrm{ml}$ denatured homogenate of $6.5 \mathrm{~g}$ liver with $72 \mu \mathrm{Ci} \mathrm{HTO}$ for $12 \mathrm{~h}$ at $37^{\circ} \mathrm{C}$ did not lead to a measurable radioactivity on the DNA isolated ( $2 \mathrm{cpm}$ as limit of detection). 
actual experiment, however, the difference between the tritium and C-14 experiment was $280 \mathrm{dpm} / \mathrm{mg}$ DNA. We therefore believe that the intracellular formation of tritiated water gives rise to an incorporation into liver DNA about 10 times higher than if the radioactivity is distributed uniformly from the beginning.

A biosynthetic incorporation of radioactivity into DNA has to be considered also with C-14 labelled compounds. The effect is most pronounced with compounds where small metabolites can carry the radioactive label, as with methylating and ethylating agents. With the pesticide dichlorvos, for instance, all radioactivity found in the DNA of rats treated with methyl-labelled chemical was found to be incorporated biosynthetically and not a result of direct methylation [289]. This finding does not, of course, exclude a methylating potential of dichlorvos in vitro [137], but it shows that, at the given dose, the pesticide did not reach the mammalian DNA as an alkylating agent.

An incorporation of such small [C-14]- or tritium-containing fragments into nucleic acid bases and sugars is very well known since the elucidation of the biosynthesis of nucleic acids [30]. However, only incomplete experimental evidence is available on its contribution to the total radioactivity of the DNA after the administration of alkylating agents. This is due to the fact that methylated or ethylated DNA is normally directly degraded by acid hydrolysis to the bases which are then chromatographed [138]. An incorporation into the sugars is only seldom accounted for, but the available evidence suggests that this incorporation is not critical [194]. The biosynthetic incorporation into the bases can, however, represent up to $20 \%$ of the total radioactivity in a shortterm experiment with a typical methylating carcinogen $[67,120,194]$. The same order of magnitude can be estimated from the apparent CBI of [C-14]bicarbonate or 1-[C-14] ]ethanol for mouse-liver DNA, $24 \mathrm{~h}$ after i.p. injection [18]: 0.3, and 4.6, resp. These numbers are small compared with the CBI for methylating carcinogens so that the measurement of a total radioactivity is still a valuable indicator for the potency of moderate or strong carcinogens.

For other classes of carcinogens, a potential release of small radioactive fragments căpable of entering biosynthetic pools of nucleic acid precursors, can only be excluded on the basis of data on metabolism. It is, however, extremely unlikely that, for example, a C-14 of an aromatic hydrocarbon or of a ringlabelled aflatoxin could become a significant biosynthetic contaminant in a DNA-binding experiment.

3. Lists of chemicals that have been tested for covalent binding to biological macromolecules under various experimental conditions

\subsection{Introduction}

More than 150 compounds have so far been tested for covalent binding to biological macromolecules. The relevance of the experiments varies with the type of macromolecule and experimental system chosen. As was outlined before, DNA binding in vivo is most valuable whereas protein binding in vitro can only be used very qualitatively. The compounds studied so far are listed in Tables 1-12 according to chemical characteristics relevant for their binding 
TABLE 1

LIST OF CHEMICALS THAT HAVE. BEEN TESTED FOR COVALENT BINDING TO BIOLOGICAL MACROMOLECULES UNDER VARIOUS EXPERIMENTAL CONDITIONS

SULPHONATES, SULPHATES, EPOXIDES, LACTONES, AZIRIDINES, EPISULPHIDES

Listed according to chemical characteristics relevant for the binding activity with a cross-reference to drugs (D) and pesticides/environmental pollutants ( $P$ ).

The number behind each compound denotes the type of experiment that has been performed on covalent binding to biological macromolecules. Only the lowest number is given even if other types of experiments have also been performed.

Refs. for compounds of class 1 and 2 are given in the corresponding Tables 13-20 and 21-25, resp.

For compounds of class $3-6$, only recent reference is given.

1 In vivo to DNA, calculation of a Covalent Binding Index, CBI.

2 In vivo to DNA, calculation of a CBI was not possible.

3 In vivo to protein.

4 In vitro to nucleic acids.

5 In vitro to protein.

6 The test for a binding to DNA was negative (varlous limits of detection!)

Methyl methanesulphonate

Ethyl methanesulphonate

Myleran (=Busulfan)

Dimethylsulphate

1,2,3,4-Diepoxy butane

1,2-Epoxybutane

$1,2,3,4$-Diepoxy cyclohexane

$\beta$-Propiolactone

Triethylenemelamine (TEM)

Triaziquone

Mitomycin C

$\begin{array}{lll} & 1 \\ \text { D } & 1 \\ & & 1 \\ & & 1 \\ & & 2 \\ & & 6 \\ & & 6 \\ & & \\ & & \\ & & 1 \\ \text { D } & & 4 \\ & & 4\end{array}$

Paul

Paul

[199]

[199]

2

4 Harbers [86]

$4 \quad$ Szybalski [267]

Tomasz [272]

3,4-Epithiobuty ronitrile

1

activity, and each chemical is given a number to denote the type of interaction studied.

All chemical classes of carcinogens are represented in this list: Tables 1 and 2 comprise of the chemicals which do not need metabolic activation (except cyclophosphamide): The directly alkylating sulphonates, sulphates, epoxides,

TABLE 2

LIST OF CHEMICALS THAT HAVE BEEN TESTED FOR COVALENT BINDING TO BIOLOGICAL MACROMOLECULES UNDER VARIOUS EXPERIMENTAL CONDITIONS

MUSTARDS ( $\beta$-CHLOROETHYLENE-DERIVATIVES)

See Table 1 for legend.

Nitrogen mustard

Sulphur mustard

Hemisulphur mustard

Aniline mustand

$\beta$-Naphthylamine mustard

Cyclophosphamide

Chlorambucil

$\begin{array}{cc} & 1 \\ & 2 \\ & 1 \\ & 2 \\ & 2 \\ \text { D } & 2 \\ \text { D } & 1 \\ & 2\end{array}$


TABLE 3

LIST OF CHEMICALS THAT HAVE BEEN TESTED FOR COVALENT BINDING TO BIOLOGICAL MACROMOLECULES UNDER VARIOUS EXPERIMENTAL CONDITIONS

HALOGENATED COMPOUNDS (MUSTARDS: SEE TABLE 2)

See Table 1 for legend.

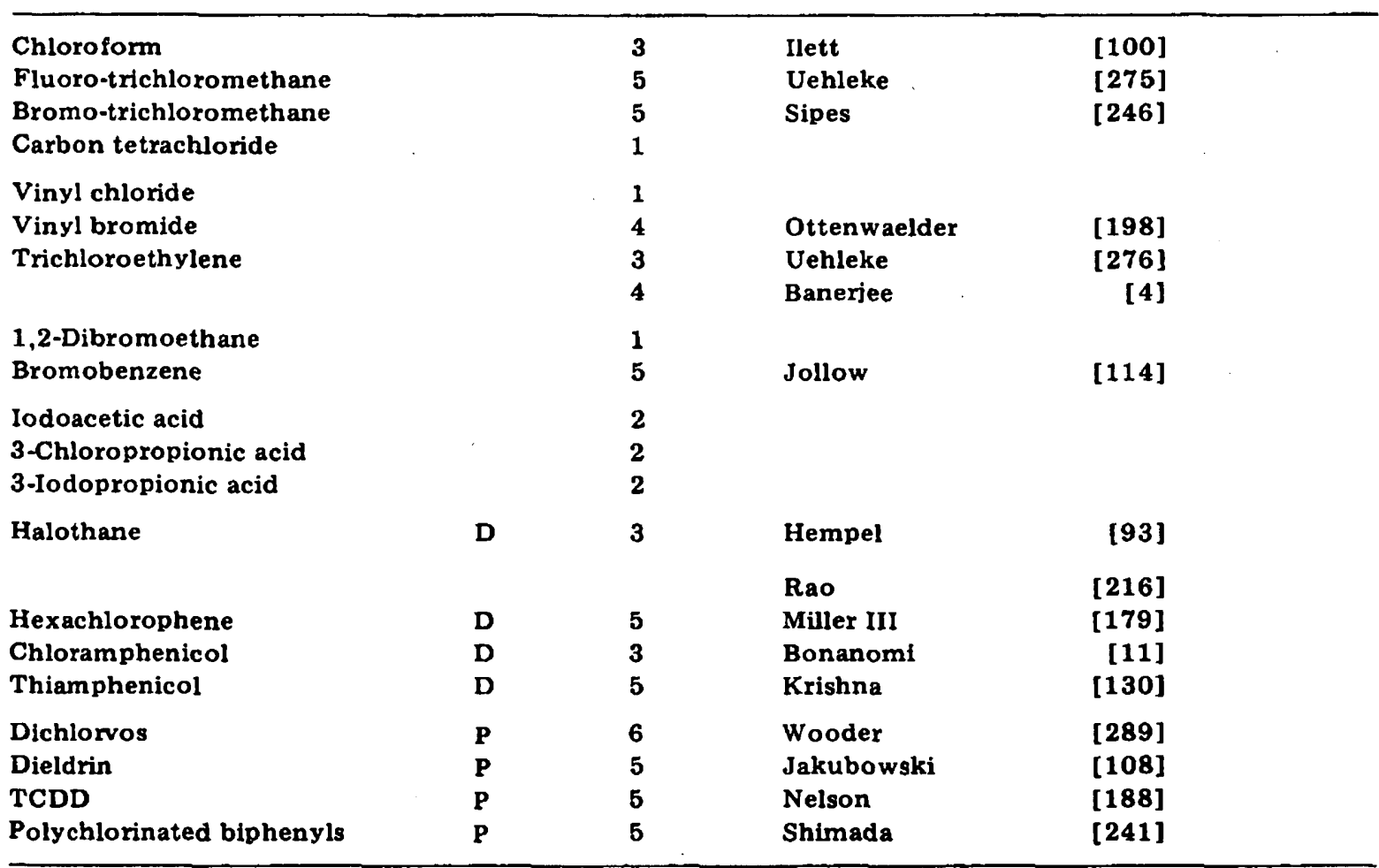

\section{TABLE 4}

LIST OF CHEMICALS THAT HAVE BEEN TESTED FOR COVALENT BINDING TO BIOLOGICAL MACROMOLECULES UNDER VARIOUS EXPERIMENTAL CONDITIONS

\section{AROMATIC HYDROCARBONS}

See Table 1 for legend.

\begin{tabular}{|c|c|c|c|}
\hline Benzene & 1 & & \\
\hline Toluene & 1 & & \\
\hline Naphthalene & 3,6 & Brookes & [21] \\
\hline Anthracene & 2 & & \\
\hline Benz $[a]$ anthracene & 1 & & \\
\hline Dibenz $[a, c]$ anthracene & 2 & \multicolumn{2}{|c|}{ at limit of detection } \\
\hline Dibenz $[a, h]$ anthracene & 2 & & \\
\hline Benzo $[a]$ pyrene & 1 & & \\
\hline Benzo $[e]$ pyrene & 6 & Brookes & [24] \\
\hline trans-Stilbene & 3 & Docks & [56] \\
\hline Styxene & 3 & Savolainen & [229] \\
\hline 7-Methylbenz $[a]$ an thracene & 4 & Newbold & [191] \\
\hline 7,12-Dimethylbenz $[a]$ anthracene & 1 & & \\
\hline 3-Methylcholanthrene & 1 & & \\
\hline 15,16-Dihydro-11-methylcyclopenta $[a]$ phenanthren-17-one & 4 & Coombs & [39] \\
\hline
\end{tabular}


TABLE 5

LIST OF CHEMICALS THAT HAVE BEEN TESTED FOR COVALENT BINDING TO BIOLOGICAL MACROMOLECULES UNDER VARIOUS EXPERIMENTAL CONDITIONS

AMINOFLUORENE- AND AMINOPHENANTHRENE-DERIVATIVES

See Table 1 for legend.

\begin{tabular}{llll}
\hline 2-Aminofluorene & 1 & & \\
2-Acetylaminofluorene & 1 & & \\
1-Hydroxy-2-acetylaminofluorene & 1 & \\
$N$-Hydroxy-2-acetylaminofluorene & 1 & \\
$N$-Acetoxy-2-acetylaminofluorene & 1 & \\
$N$-Glucuronyl-10)-2-acetylaminofluorene & 1 & & \\
$N$-Acetoxy-2-acetylaminophenanthrene & 4 & Lang & [133] \\
$N$-Sulfonoxy-2-acetylaminophenanthrene & 4 & Scribner & [235] \\
$N$-(O-Glucuronyl)-2-acetylaminophenanthrene & 4 & Irving & {$[104]$} \\
\hline
\end{tabular}

\section{TABLE 6}

LIST OF CHEMICALS THAT HAVE BEEN TESTED FOR COVALENT BINDING TO BIOLOGICAL MACROMOLECULES UNDER VARIOUS EXPERIMENTAL CONDITIONS

\section{AZO-DERIVATIVES OF AROMATIC AMINES}

See Table 1 for legend.

$\begin{array}{ll}\text { N-Methyl-4-aminoazobenzene } & 1 \\ \text { 4-Dimethylaminoazobenzene } & 1 \\ \text { 2-Methyl-4-dimethylaminoazobenzene } & 1 \\ \text { 3'-Methyl-4-dimethylaminoazobenzene } & 1 \\ \text { 3'-Trifluoromethyl-4-dimethylaminoazobenzene } & 1 \\ \text { o-Aminoazotoluene } & 1 \\ \text { p-Aminoazobenzene } & 1\end{array}$

\section{TABLE 7}

LIST OF CHEMICALS THAT HAVE BEEN TESTED FOR COVALENT BINDING TO BIOLOGICAL MACROMOLECULES UNDER VARIOUS EXPERIMENTAL CONDITIONS

\section{OTHER AROMATIC AMINES}

See Table 1 for legend.

\begin{tabular}{llll}
\hline Aniline & 1 & & \\
2.4-Diaminotoluene & 3 & Dybing & [59] \\
2,4-Diaminoanisole & 3 & Dybing & {$[59]$} \\
3-Chloro-4-methylaniline & 3 & Giri & {$[76]$} \\
2-Naphthylamine & 1 & & \\
N-Hydroxy-1-naphthylamine & 4 & Kadlubar & {$[116]$} \\
N-Hydroxy-2-naphthylamine & 4 & Kadlubar & {$[115]$} \\
N-Hydroxy-4-aminobiphenyl & 4 & Kadlubar & {$[115]$} \\
N-Hydroxy-4-acetylaminobiphenyl & 1 & & \\
N-Hydroxy-4-acetylamino-4'-fluorobiphenyl & 1 & & Lang \\
N-Acetoxy-4-acetylaminobiphenyl & 4 & & \\
trans-Dimethylaminostilbene & 1 & &
\end{tabular}


TABLE 8

LIST OF CHEMICALS THAT HAVE BEEN TESTED FOR COVALENT BINDING TO BIOLOGICAL MACROMOLECULES UNDER VARIOUS EXPERIMENTAL CONDITIONS

ALIPHATIC AMINES, HYDRAZINES, AZOXY - AND NITRO-DERIVATIVES, TRIAZENES

See Table 1 for legend.

\begin{tabular}{|c|c|c|c|c|}
\hline Dopa & D & 5 & Scheulen & [231] \\
\hline \multirow[t]{2}{*}{ Dopamine } & $\mathbf{D}$ & 5 & Scheulen & [231] \\
\hline & & & Rotman & [226] \\
\hline 6-Hydroxy-dopamine & & $\mathbf{5}$ & Rotman & [226] \\
\hline 5,6-Dihydro $x$ y try ptamine & & 5 & Rotman & [226] \\
\hline 5,7-Dihy droxy try ptamine & & $\mathbf{5}$ & Rotman & [226] \\
\hline Norepinephrine & $\mathbf{D}$ & 5 & Rotman & [226] \\
\hline Imipramine & $\mathbf{D}$ & 3 & Kappus & [118] \\
\hline Isoproterenol & $\mathbf{D}$ & 3 & Remmer & [218] \\
\hline Tripelennamine & $\mathbf{D}$ & $\mathbf{3}$ & Rao & [215] \\
\hline 1,2-Dimethylhy drazine & & 1 & & \\
\hline Acetylhydrazine (from isoniazid D) & & 3 & Nelson & [187] \\
\hline Isopropylhydrazine (from iproniazid D) & & 3 & Nelson & [187] \\
\hline Methylazoxymethanol acetate (from cycasin) & & 1 & & \\
\hline Cycasin & & 2 & & \\
\hline Methylphenyltriazene & & 1 & & \\
\hline Dimethylphenyltriazene & & 1 & & \\
\hline Dacarbazine & $\mathbf{D}$ & 2 & & \\
\hline 4-Nitroquinoline-1-oxide & & 2 & & \\
\hline 4-Hydroxyaminoquinoline-1-oxide & & 2 & & \\
\hline 1-Nitro-9-(3'-dimethyl-n-propylamino)acridine & & 2 & & \\
\hline
\end{tabular}

TABLE 9

LIST OF CHEMICALS THAT HAVE BEEN TESTED FOR COVALENT BINDING TO BIOLOGICAL MACROMOLECULES UNDER VARIOUS EXPERIMENTAL CONDITIONS

\section{N-NITROSO-DERIVATIVES}

See Table 1 for legend.

$\begin{array}{lll}\text { Dimethylnitrosamine } & 1 & \\ \text { Diethylnitrosamine } & 1 & \\ \text { Methylnitrosourea } & 1 & \\ \text { Ethylnitrosourea } & 1 & \\ \text { Methylnitrosourethane } & 2 & \\ \text { Methylnitronitrosoguanidine } & 1 & \\ \text { Nitrosohexamethyleneimine } & 1 & \\ \text { Nitrosomorpholine } & 1 & \\ \text { Methylnitrosoaniline } & 1 & \\ \text { Methylnitrosocyclohexylamine } & 1 & \\ \text { Nitrosoazetidine } & 1 & \text { Rao } \\ \text { Nitrosopyrrolidine } & 1 & \text { Regan } \\ \text { Nitrosopiperidine } & 1 & {[217]} \\ \text { Dinitrosopiperazine } & 1 & \\ \text { Nitrosotripelennamine } & 3 & \\ \text { Nitrosocarbaryl } & 4 & \end{array}$


TABLE 10

LIST OF CHEMICALS THAT HAVE BEEN TESTED FOR COVALENT BINDING TO BIOLOGICAL MACROMOLECULES UNDER VARIOUS EXPERIMENTAL CONDITIONS

\section{NATURALLY OCCURRING COMPOUNDS}

See Table 1 for legend.

\begin{tabular}{llll}
\hline Aflatoxin $B_{1}$ & 1 & & \\
Aflatoxin $B_{2}$ & 1 & \\
Aflatoxin $G_{1}$ & 1 & & \\
Aflatoxin $M_{1}$ & 1 & & \\
$1^{\prime}$-Hydroxysafrole & 1 & & \\
Retronecine-7,9-bis- $N$-ethylcarbamate & 3 & Mattocks & {$[171]$} \\
Synthanecine A bis- $N$-ethylcarbamate & 3 & Mattocks & {$[171]$} \\
Xanthotoxin & 4 & Kittler & {$[119]$} \\
Angelicin & 4 & Kittler & {$[119]$} \\
Phorbol-1 2,13-didecanoate & 3 & Helmes & {$[92]$} \\
Phorbol-12,13-dibenzoate & 3 & Helmes & {$[92]$} \\
Cholesterol & 4 & Zachariah & {$[293]$} \\
Cholic acid & 4 & Zachariah & {$[293]$} \\
Deoxycholic acid & 4 & Zachariah & {$[293]$} \\
\hline
\end{tabular}

lactones, aziridines, and episulphides (= thiiranes) (Table 1), and the mustards ( $\beta$-chloroethylene derivatives, Table 2 ).

All the other chemicals require metabolic activation with only very few exceptions and are grouped as follows: halogenated compounds, except mustards (Table 3), aromatic hydrocarbons (Table 4), the long list of aromatic amines which have been subdivided for practical purposes into aminofluorene and aminophenanthrene derivatives (Table 5), azo-derivatives (Table 6) and other aromatic amines (Table 7). Table 8 includes the rest of the nitrogen-con-

TABLE 11

LIST OF CHEMICALS THAT HAVE BEEN TESTED FOR COVALENT BINDING TO BIOLOGICAL MACROMOLECULES UNDER VARIOUS EXPERIMENTAL CONDITIONS

PHARMACEUTICAL DRUGS

See Table 1 for legend.

\begin{tabular}{llllr}
\hline $\begin{array}{l}\text { Phenacetin } \\
\text { N-Hydroxyphenacetin }\end{array}$ & D & 5 & Hinson & {$[96]$} \\
Acetaminophen (=paracetamol) & D & 5 & $\begin{array}{l}\text { Mulder } \\
\text { Hinson } \\
\text { Labadorios } \\
\text { Thorgeirsson }\end{array}$ \\
Antipyrine & & 3 & Tabarelli-Poplawski & {$[132]$} \\
Morphine & D & & Deutsch & {$[271]$} \\
Estrone & D & 5 & Jaggi & {$[54]$} \\
Ethinylestradiol & D & 1 & Jaggi & {$[107]$} \\
nor-Ethynodrel & D & 1 & Chen & {$[107]$} \\
Diethylstilbestrol & D & 5 & unpublished & {$[32]$} \\
Rifampicine & D & 1 & Bolt & {$[9]$} \\
Rifampicine-quinone & D & 5 & Bolt & {$[9]$} \\
Mycophenolic acid & & 4 & Nery & {$[189]$} \\
Furosemide & D & 4 & Wirth & {$[286]$} \\
Warfarin & D & 5 & Lorusso & {$[154]$} \\
\hline
\end{tabular}


TABLE 12

LIST OF CHEMICALS THAT HAVE BEEN TESTED FOR COVALENT BINDING TO BIOLOGICAL MACROMOLECULES UNDER VARIOUS EXPERIMENTAL CONDITIONS

PESTICIDES, ENVIRONMENTAL POLLUTANTS, MISCELLANEOUS CHEMICALS

See Table 1 for legend.

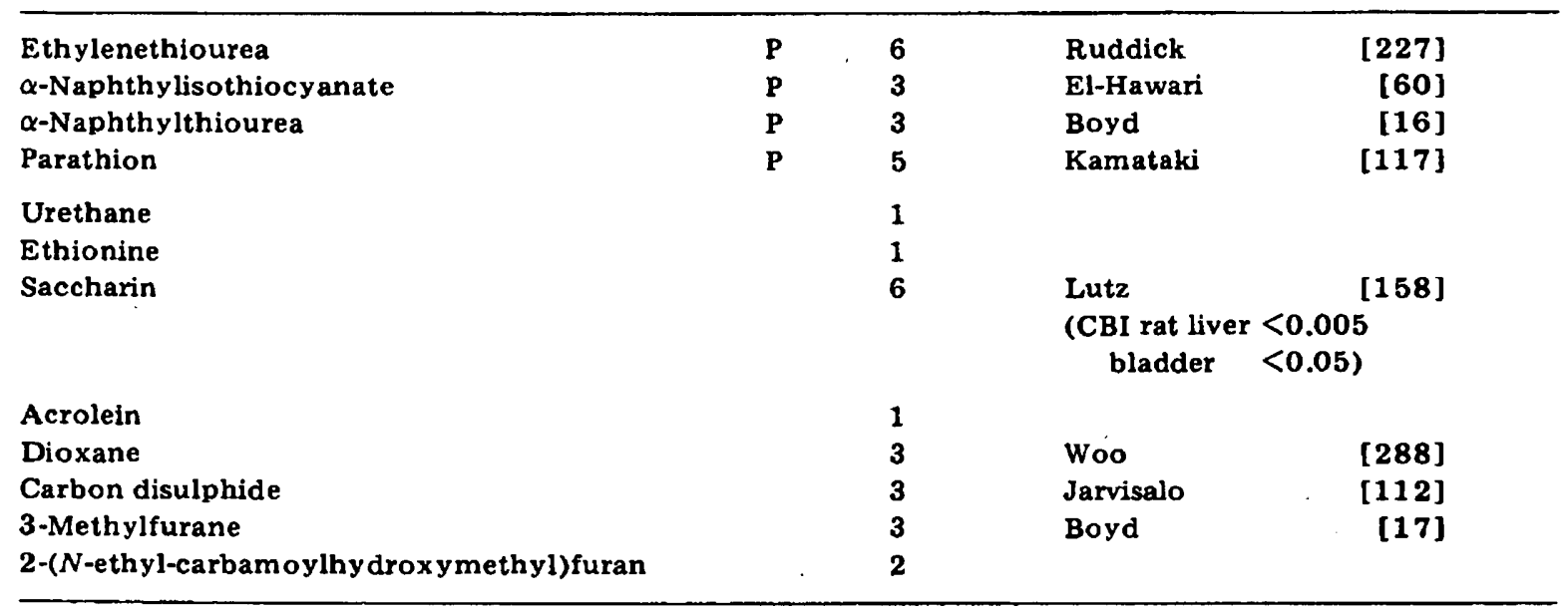

taining compounds like aliphatic amines, hydrazines, azoxy and nitro derivatives, as well as triazenes. The group of $N$-nitroso compounds (Table 9 ) is very well studied for their DNA-binding activity. Among the naturally occurring compounds (Table 10) are some of the most potent carcinogens. A number of pharmaceutical drugs (Table 11) have also been tested, predominantly for their binding to protein. Drugs are also found in many of the other groups of related chemicals where they are marked with the letter D for cross-reference (Tables $1-3,8)$. It is interesting to note that among the 150 chemicals listed in Tables 1-12 there are 30 pharmaceutical drugs that have been found to undergo a covalent binding to biological macromolecules. This is not so surprising for the anti-cancer drugs which have to interact with the growth control of cells and which do this primarily by reaction with DNA. The situation is more critical with some of the very widely used analgesics which should be investigated more thoroughly because the use of high doses of this group of compounds can last for many years.

Table 12 lists all the compounds which do not belong clearly to any of the afore-mentioned groups. It includes pesticides and environmental pollutants some of which can also be found in Table 3 with the halogenated chemicals.

The classification 1-6 has been done according to decreasing predictive value for a correlation of binding to carcinogenicity.

\subsection{Covalent binding to DNA in vivo. Calculation of a $C B I$}

Class 1 comprises of 64 chemicals where a Covalent Binding Index, CBI, to DNA in vivo could be calculated. There are class 1 members in all groups of chemicals except among the pesticides which have not been studied extensively. These chemicals are compiled in Tables $13-20$ with complete reference to the literature. 


\section{TABLE 13}

\section{IN VIVO BINDING OF CHEMICALS TO DNA}

\section{CALCULATION OF COVALENT BINDING INDICES, "CBI"}

The "Covalent Binding Index", CBI, is defined as DNA binding per dose, in the units:

$\mathrm{CBI}=\frac{\text { micromole chemical } / \text { mole nucleotides }}{\mathrm{mmole} \text { chemical } / \mathrm{kg} \text { body weight }}$

If, with methylating or ethylating agents, guanine-7-alkylations were the only data available, this was assumed to represent $80 \%$ of the total amount of DNA adducts.

$$
\begin{array}{ll}
\mathrm{S}=\text { species: } & \mathbf{r}=\text { rat } \\
\mathrm{m}=\text { mouse } \\
\mathrm{h}=\text { hamster } \\
\mathrm{g}=\text { guinea pig } \\
\mathrm{p}=\text { pig }
\end{array}
$$

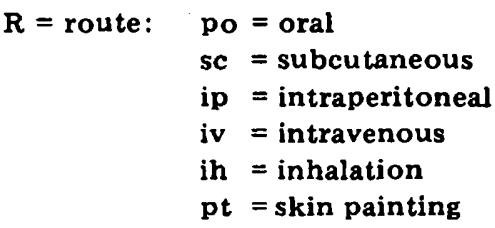

Time between administration and sacrifice:

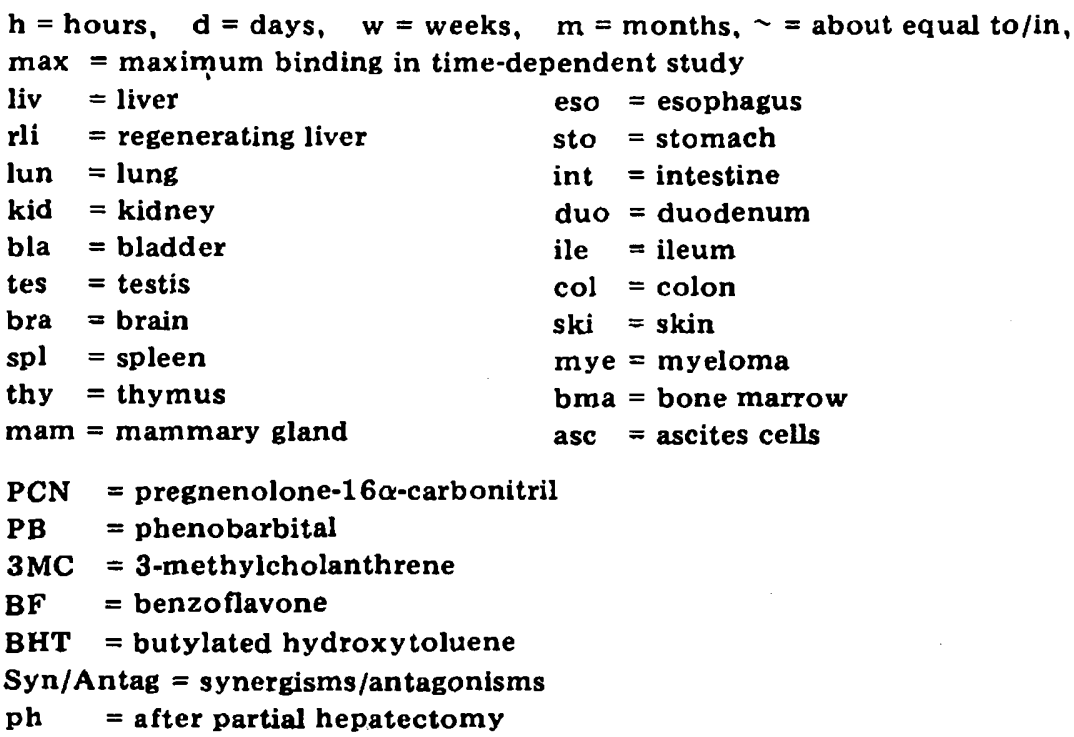

SULPHONATES, SULPHATES, AZIRIDINES, EPISULPHIDES, MUSTARDS, OTHER HALOGEN-

\begin{tabular}{|c|c|c|c|c|c|c|c|}
\hline Compound & $\mathbf{S}$ & $\mathbf{R}$ & Time & Org & CBI & $\begin{array}{l}\text { Other Organs, } \\
\text { Remarks }\end{array}$ & Ref. \\
\hline $\begin{array}{l}\text { Methyl methane- } \\
\text { sulphonate }\end{array}$ & $\begin{array}{l}\mathbf{r} \\
\mathbf{r} \\
\mathbf{r}\end{array}$ & $\begin{array}{l}\text { iv } \\
\text { ip } \\
\text { iv }\end{array}$ & $\begin{array}{l}4 h \\
4 h=\max \\
2 h\end{array}$ & $\begin{array}{l}\text { liv } \\
\text { liv } \\
\text { liv }\end{array}$ & $\begin{array}{l}556 \\
272 \\
360\end{array}$ & $\begin{array}{l}16 \mathrm{~h} \text { : lower } \\
\sim \text { kid, lun, bra, }>\text { tes } \\
\sim \text { bra, int }\end{array}$ & $\begin{array}{l}\text { Swann }[261] \\
\text { O'Connor }[194] \\
\text { Kleihues }[120]\end{array}$ \\
\hline $\begin{array}{l}\text { Ethyl methane- } \\
\text { sulphonate }\end{array}$ & $\mathbf{r}$ & ip & $17 \mathrm{~h}$ & liv & 62 & $\sim$ lun, kid & Swann [262] \\
\hline Myleran (=busulfan) & $\begin{array}{l}\mathbf{r} \\
\mathbf{m}\end{array}$ & $\begin{array}{l}\text { ip } \\
\text { ip }\end{array}$ & $\begin{array}{l}2 \mathrm{~h} \\
5 \mathrm{~h}\end{array}$ & $\begin{array}{l}\text { rli } \\
\text { liv }\end{array}$ & $\begin{array}{r}150 \\
21\end{array}$ & $\begin{array}{l}\text { ph } \\
\sim \text { leukemic spl }\end{array}$ & $\begin{array}{l}\text { Trams [273] } \\
\text { Brookes [23] }\end{array}$ \\
\hline Dimethyl sulphate & $\mathbf{r}$ & iv & $4 \mathrm{~h}$ & liv & 37 & <lun, kid & Swann [261] \\
\hline $\begin{array}{l}\text { Triethylene- } \\
\text { melamine (TEM) }\end{array}$ & $\mathbf{r}$ & ip & $\mathbf{2 h}$ & rli & 308 & ph & Trams [273] \\
\hline $\begin{array}{l}\text { 3,4-Epithiobutyro- } \\
\text { nitrile }\end{array}$ & $\mathbf{r}$ & po & $\begin{array}{r}8 \mathrm{~h} \\
12 \mathrm{~h}\end{array}$ & $\begin{array}{l}\text { liv } \\
\text { liv }\end{array}$ & $\begin{array}{l}0.5 \\
1\end{array}$ & & unpublished \\
\hline Nitrogen mustard & $\begin{array}{l}\mathbf{r} \\
\mathbf{m}\end{array}$ & ip & $6 \mathrm{~h}$ & liv & 83 & multiple injections & $\begin{array}{l}\text { Wheeler }[284] \\
\text { Wheeler }[284]\end{array}$ \\
\hline
\end{tabular}
ATED COMPOUNDS 
TABLE 13 CONTINUED

\begin{tabular}{|c|c|c|c|c|c|c|c|}
\hline Compound & $\mathbf{s}$ & $\mathbf{R}$ & Time & Org & CBI & $\begin{array}{l}\text { Other Organs, } \\
\text { Remarks }\end{array}$ & Ref. \\
\hline $\begin{array}{l}\text { Hemisulphur } \\
\text { mustard }\end{array}$ & $\mathbf{m}$ & ip & $1 \mathrm{~h}$ & liv & 525 & $\begin{array}{l}\text { <leukemic spleen } \\
\text { >hepatoma }\end{array}$ & Brookes [23] \\
\hline Cyclophosphamide & $\mathbf{r}$ & ip & $24 \mathrm{~h}$ & liv & 62 & & Harbers [86] \\
\hline $\begin{array}{l}\text { Carbon } \\
\text { tetrachloride }\end{array}$ & m & ip & $12 \mathrm{~h}$ & liv & 51 & rat: only RNA & Rocchi [221] \\
\hline Vinyl chloride & $\mathbf{r}$ & ih & $5 \mathrm{~h}$ & liv & 525 & & Bolt [10] \\
\hline 1,2-Dibromoethane & $\mathbf{r}$ & ip & $24 \mathrm{~h}$ & liv & 180 & $\sim$ kid: >others & Hill [95] \\
\hline
\end{tabular}

Some recent, so far unpublished CBI from this laboratory have been included but are not discussed in detail in this review.

1,2-Epithiobutyronitrile (Table 13), as the first example for the effectiveness of DNA binding in vivo of a natural plant constituent containing the threemembered thiirane ring system, the sulphur analogue to the epoxide or the aziridine.

Aflatoxin $M_{1}$ (Table 19), a metabolite of aflatoxin $B_{1}$ secreted in the milk of cows which have been fed aflatoxin $B_{1}$ containing feed.

Metabolites of aflatoxin $B_{1}$ bound to the macromolecules of the liver of a rat which has been administered [C-14] aflatoxin $B_{1}$. This study of the 'relay' toxicity of a food residue is discussed in section 4.1.

Diethylstilbestrol (Table 20). DNA binding was higher in the hamster than in the rat. This corresponds to the observed incidence of tumors.

\subsection{Covalent binding to DNA in vivo. No calculation of a CBI possible}

Class 2 comprises of about 20 compounds which have been shown to interact covalently with DNA in vivo but where either the literature data was insufficient for the calculation of a CBI or where the binding was measured at the site of administration so that a calculation of a dose per $\mathrm{kg}$ body weight is not a reasonable means for standardizing. Tables $21-25$ list these compounds. In addition, chemicals of class 1 that have been studied under class 2 conditions are repeated, because there are some interesting comparative data on DNA binding of related chemicals and comparisons of DNA binding at the site of administration after various pretreatments. This is the case for many skin paintings with polycyclic aromatic hydrocarbons, i.e. for many of the very early and pioneering experiments.

\subsection{Covalent binding to protein in vivo}

Protein-binding in vivo (class 3 in Tables 1-12) has been detected with additional 27 compounds. For many of these it is only a matter of the limit of detection that DNA binding was not established except for the very unstable directly alkylating or ultimate carcinogens that are too short-lived to reach DNA. 


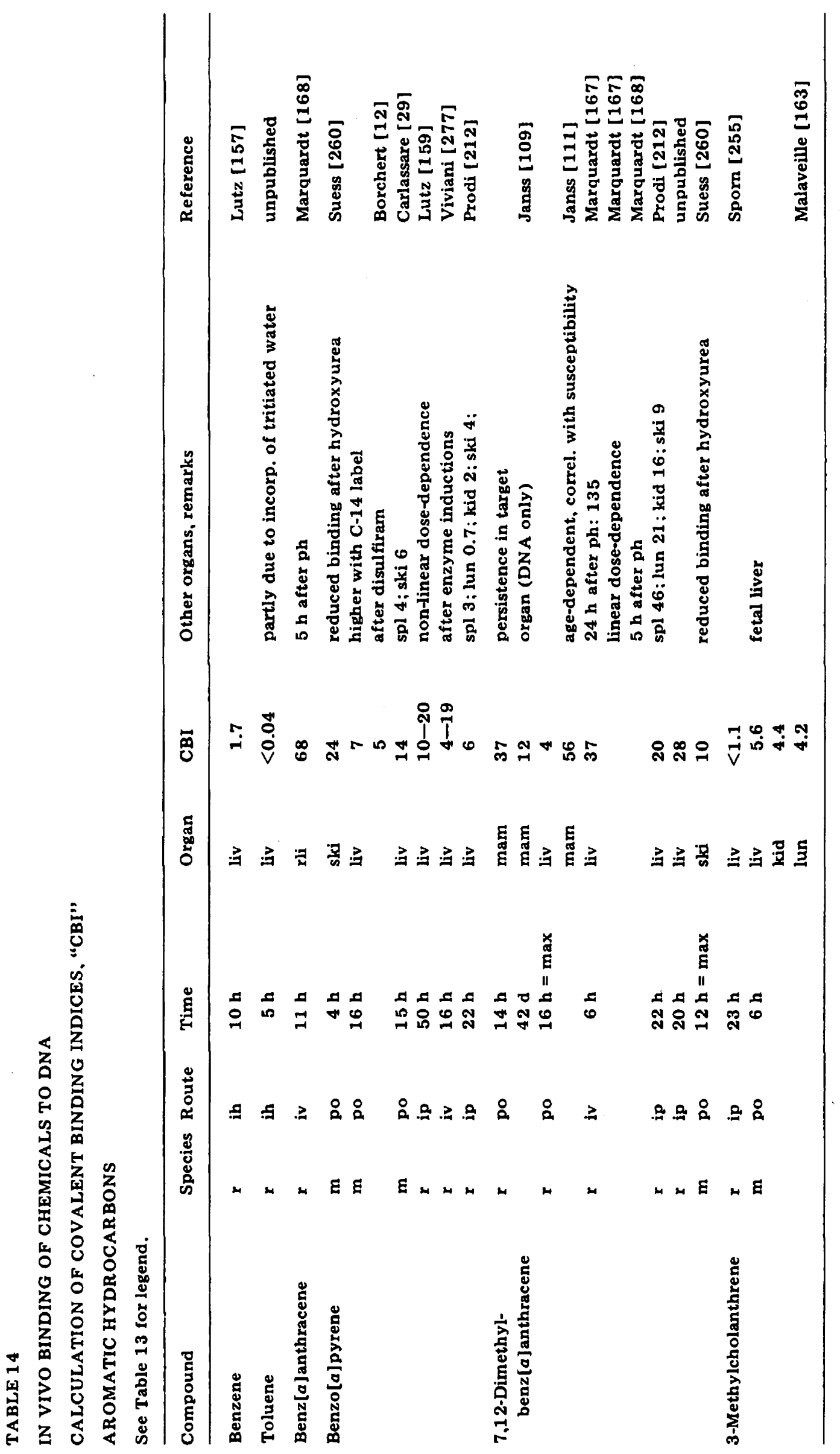




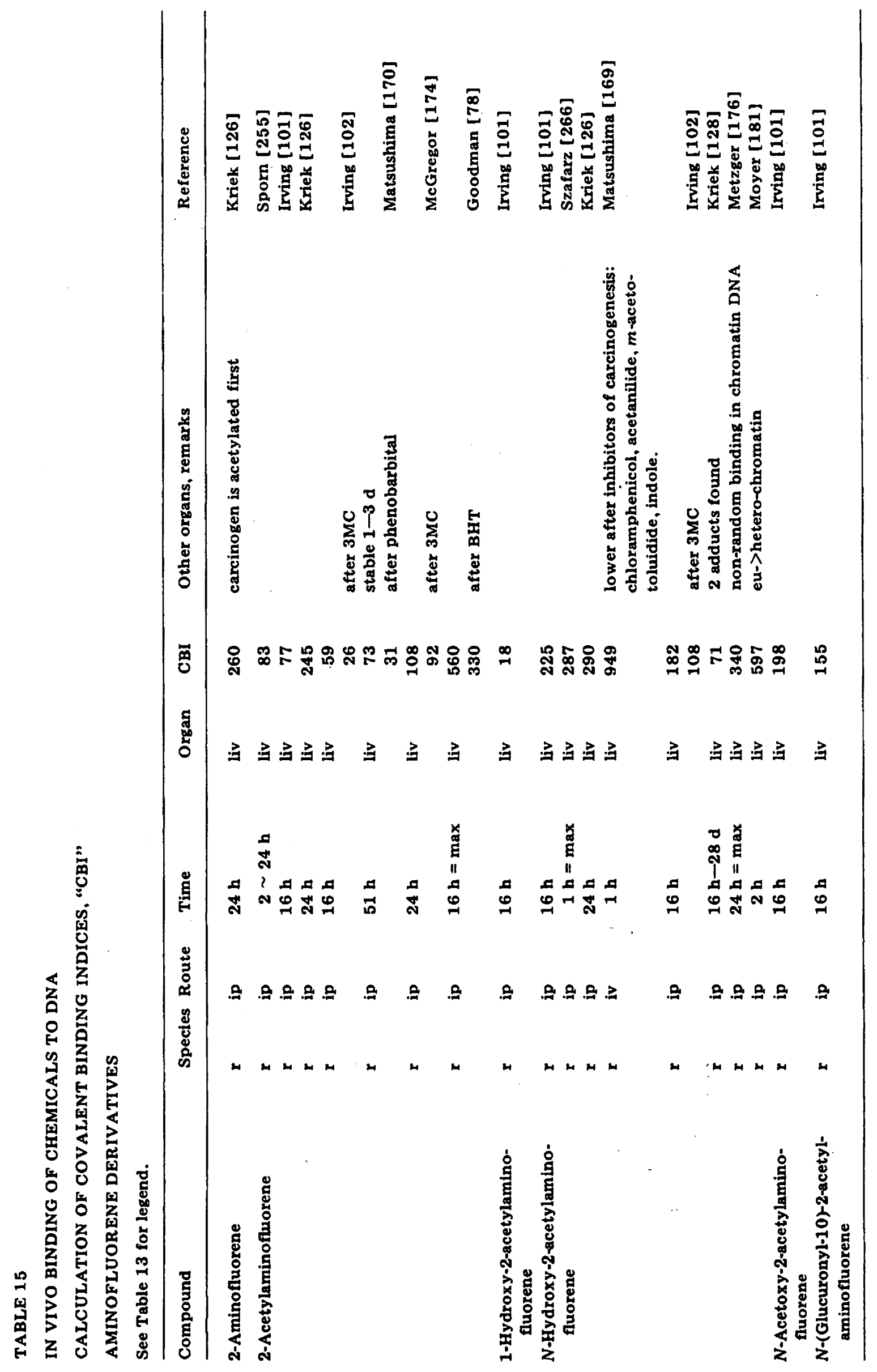




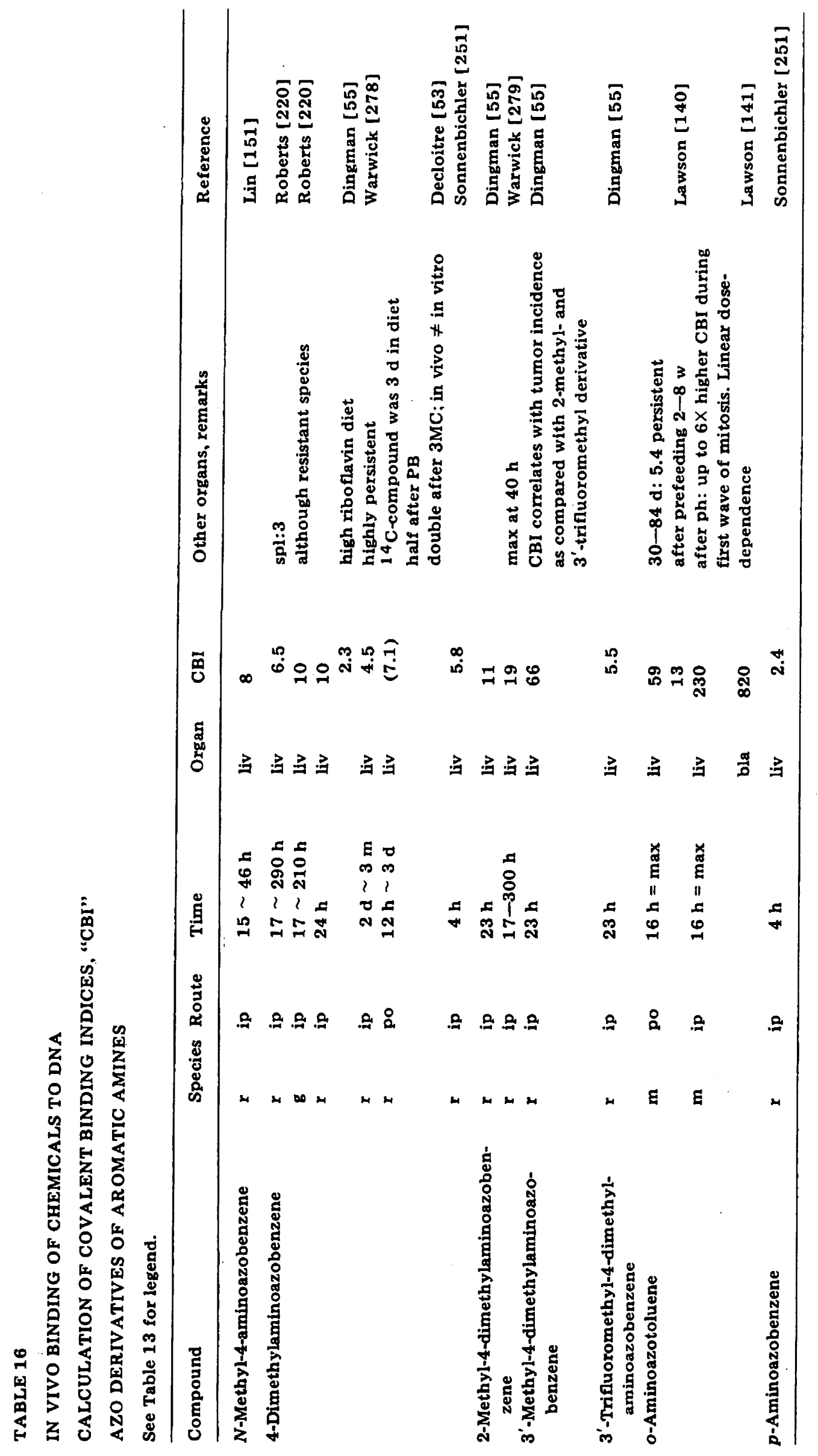




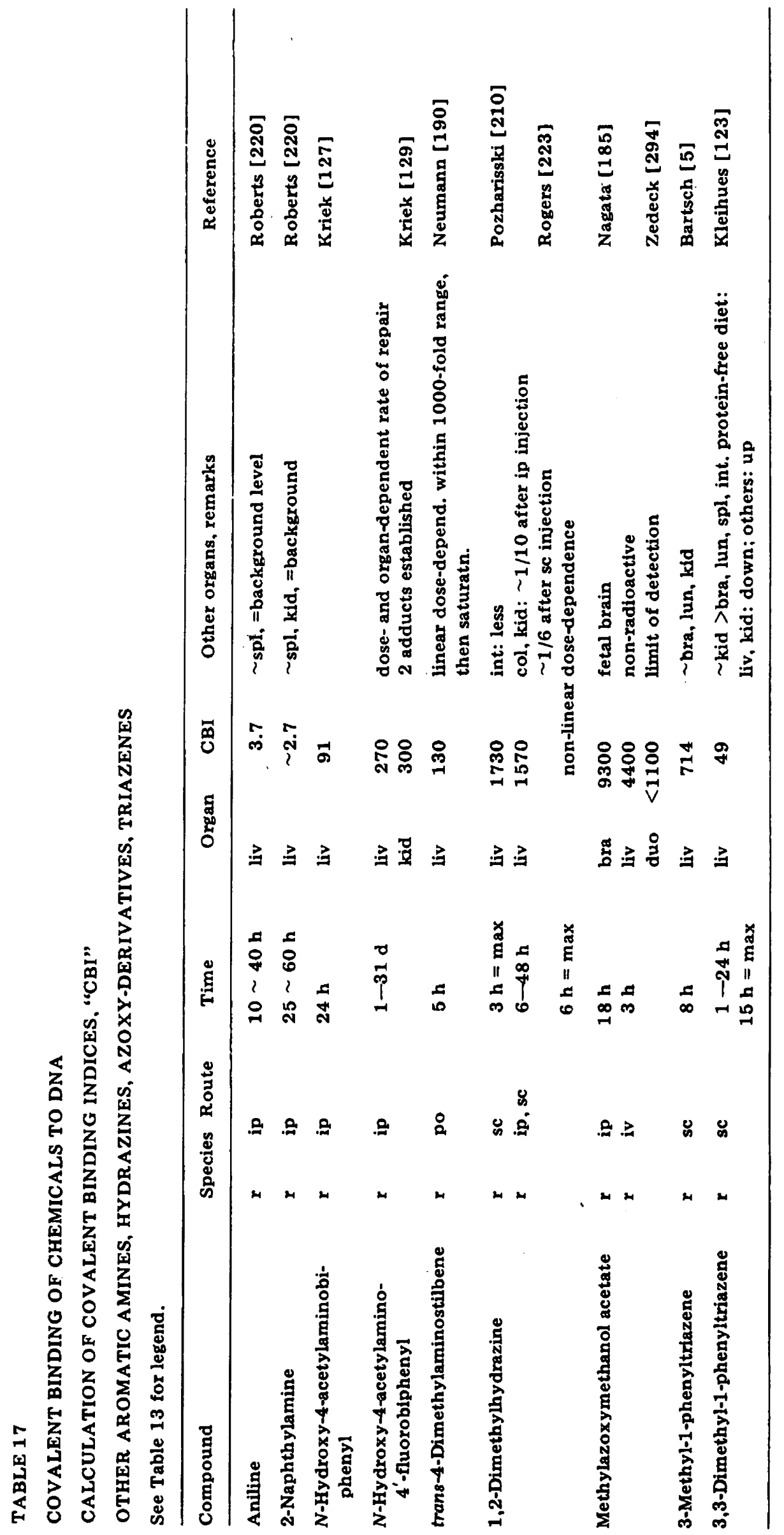




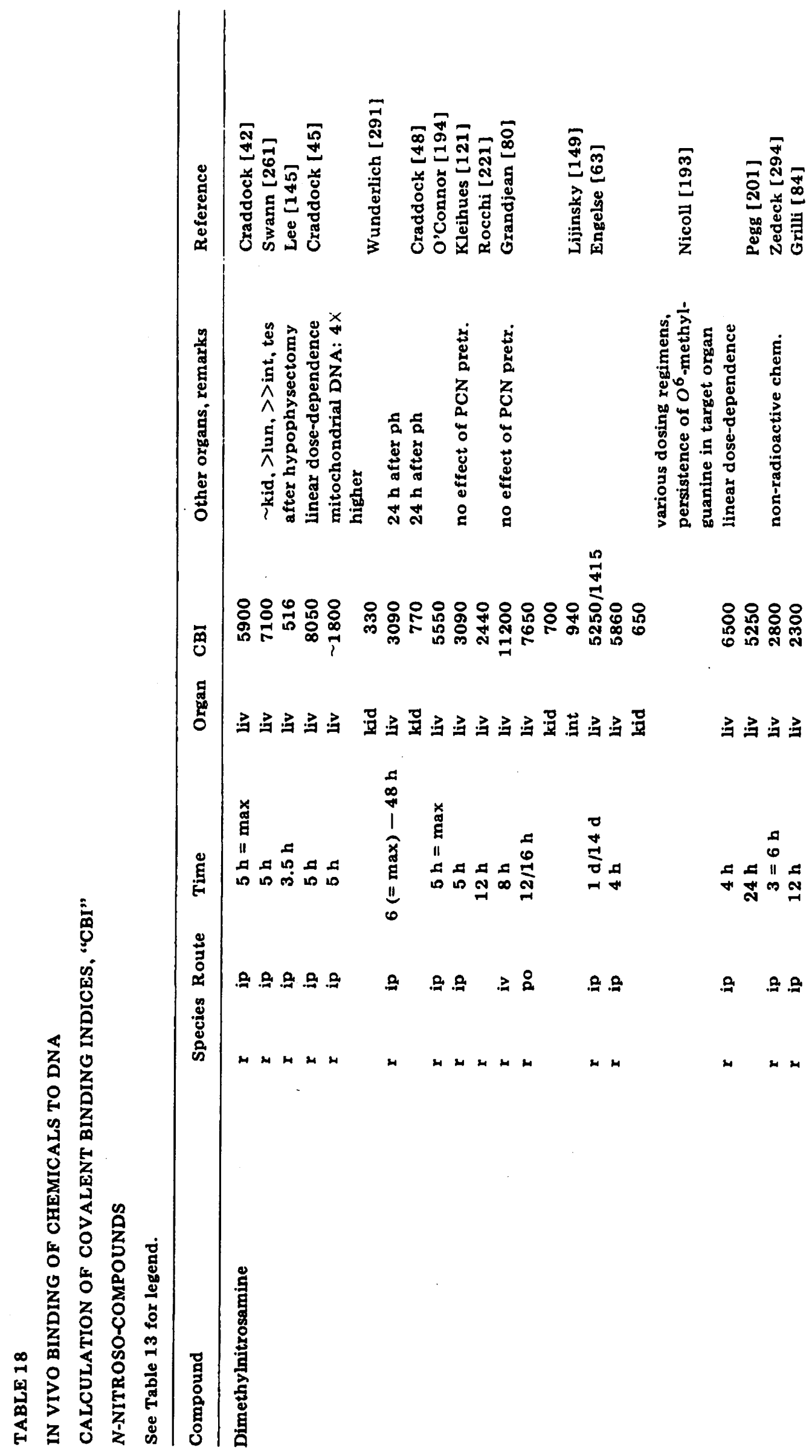




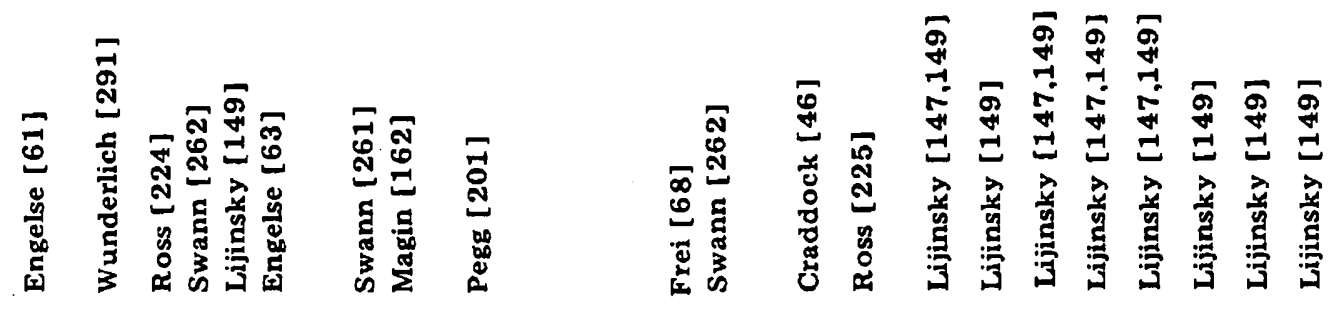

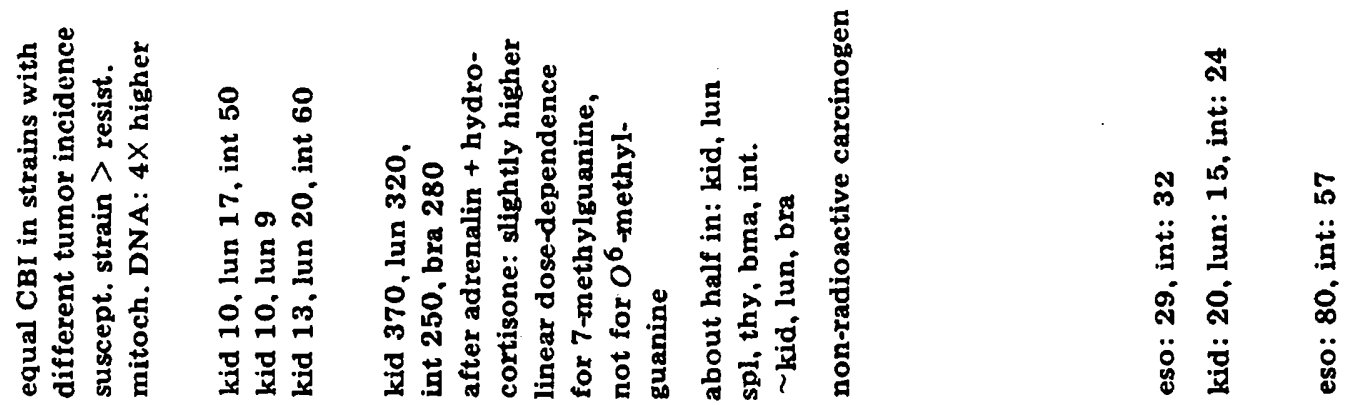

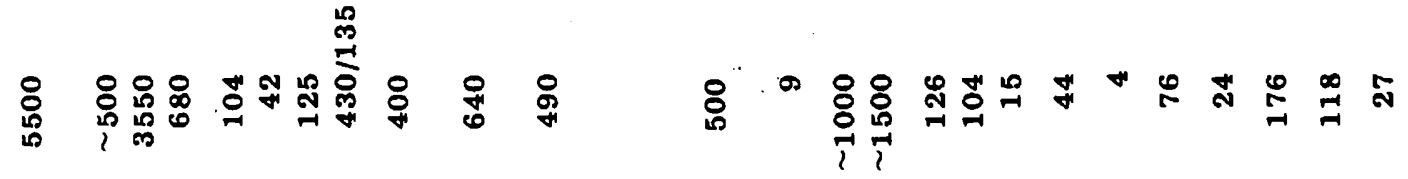

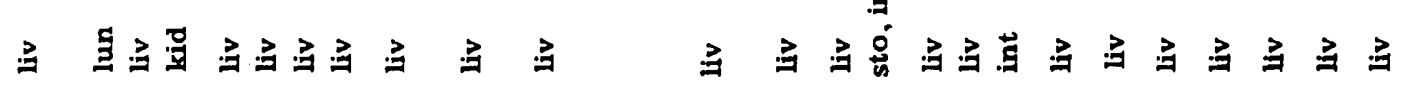

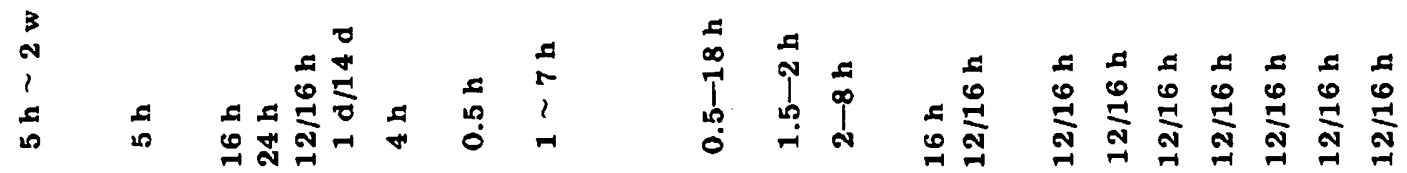

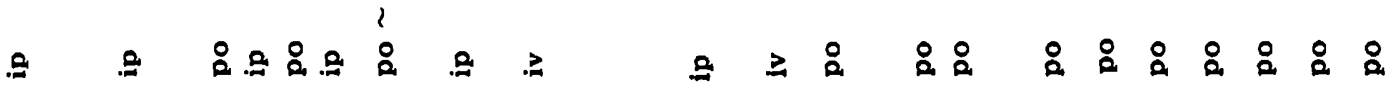
E 5 \&

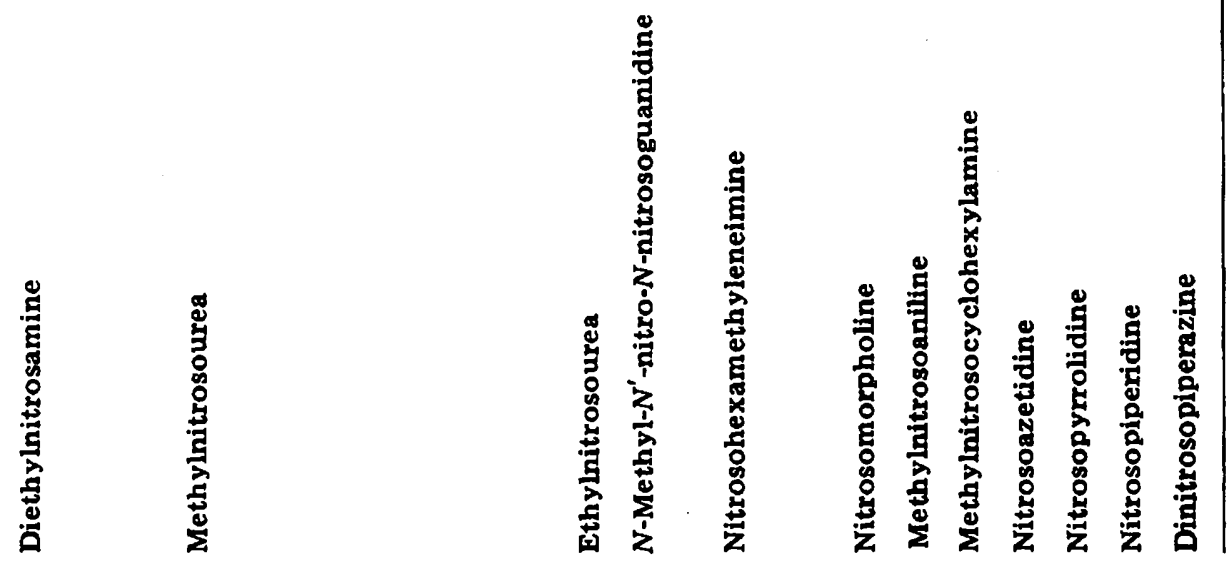




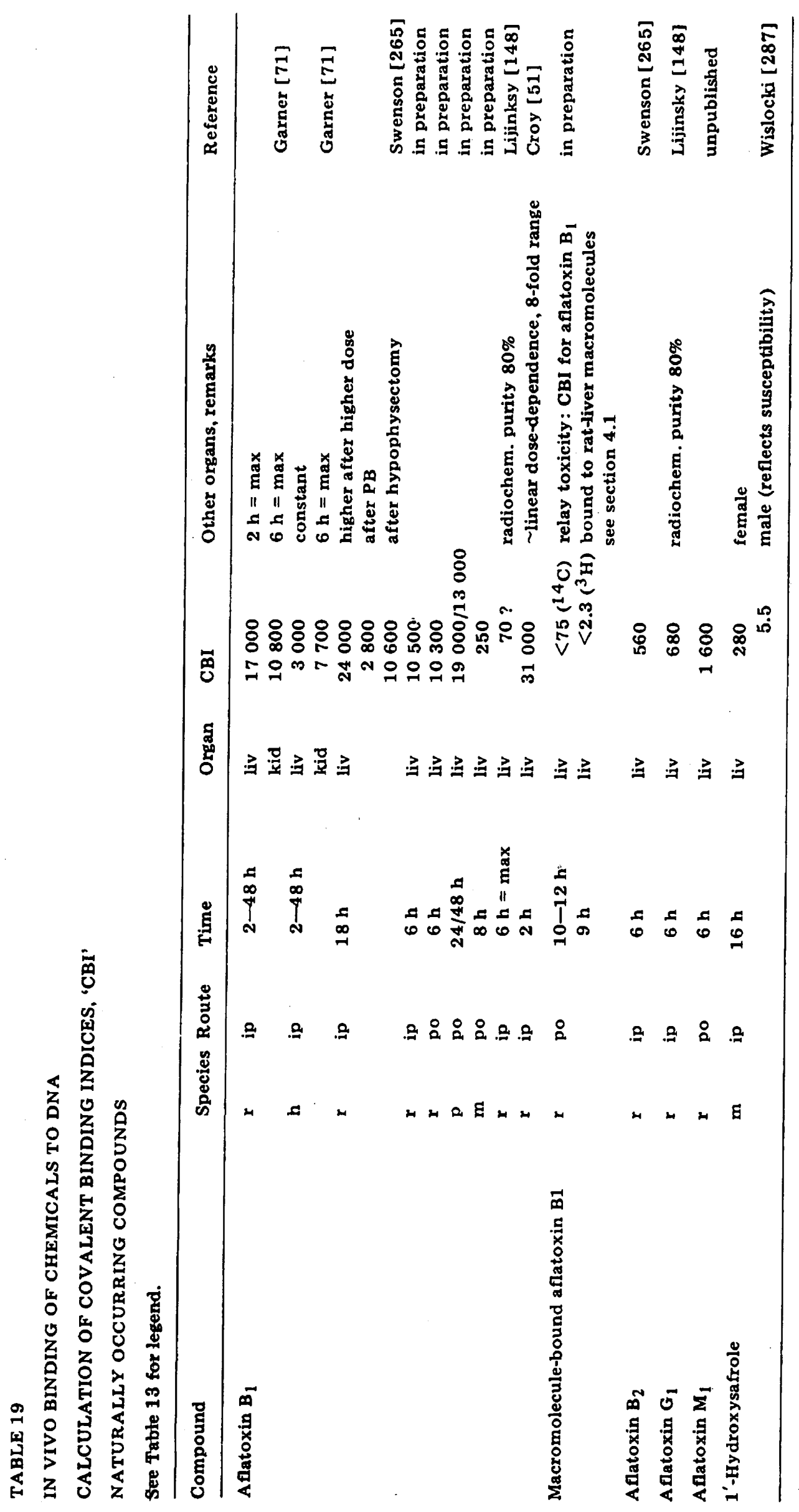


TABLE 20

IN VIVO BINDING OF CHEMICALS TO DNA

CALCULATION OF COVALENT BINDING INDICES, 'CBI'

PHARMACEUTICAL DRUGS, MISCELLANEOUS COMPOUNDS

See Table 13 for legend.

\begin{tabular}{|c|c|c|c|c|c|c|c|}
\hline Compound & $\mathbf{S}$ & $\mathbf{R}$ & Time & Organ & \multicolumn{2}{|c|}{ Remarks } & Reference \\
\hline Estrone & $\mathbf{r}$ & po & $8 \mathrm{~h}$ & liv & \multicolumn{2}{|l|}{1.1} & Jaggi [107] \\
\hline Ethinylestradiol & $\mathbf{r}$ & po & $8 \mathrm{~h}$ & liv & \multicolumn{2}{|l|}{1.5} & Jaggi [107] \\
\hline Diethylstilbestrol & $\begin{array}{l}\mathbf{r} \\
\mathbf{h} \\
\mathbf{r}\end{array}$ & $\begin{array}{l}\text { po } \\
\text { sc } \\
\text { sc }\end{array}$ & $\begin{array}{l}8 \mathrm{~h} \\
8 \mathrm{~h} \\
8 \mathrm{~h}\end{array}$ & $\begin{array}{l}\text { liv } \\
\text { liv } \\
\text { liv }\end{array}$ & $\begin{array}{l}0.4 \\
5 \\
0.6\end{array}$ & $\begin{array}{l}\text { kid, spl, Iun }<0.05 \\
\text { kid: } 1 \\
\text { kid: } \sim 0.1\end{array}$ & $\begin{array}{l}\text { unpublished } \\
\text { unpublished } \\
\text { unpublished }\end{array}$ \\
\hline \multirow[t]{2}{*}{ Urethane } & $\mathbf{m}$ & ip & $24 \mathrm{~h}$ & $\begin{array}{l}\text { liv } \\
\text { lun }\end{array}$ & $\begin{array}{l}\sim 35 \\
\sim 84\end{array}$ & $\begin{array}{l}\text { (includes in corpora- } \\
\text { tion of labelled } \\
\text { carbon dioxide) }\end{array}$ & Boyland [18] \\
\hline & $\begin{array}{l}\mathbf{m} \\
\mathbf{m} \\
\mathbf{m} \\
\mathbf{r} \\
\mathbf{r}\end{array}$ & $\begin{array}{l}\text { ip } \\
\text { ip } \\
\text { ip } \\
\text { ip } \\
\text { ip }\end{array}$ & $\begin{array}{l}2-24 \mathrm{~h} \\
4-16 \mathrm{~h} \\
24 \mathrm{~h} \\
6 \mathrm{~h} \\
12 \mathrm{~h}=\max \\
24 \mathrm{~h} \\
24 \mathrm{~h}\end{array}$ & $\begin{array}{l}\text { liv } \\
\text { liv } \\
\text { liv } \\
\text { liv } \\
\text { liv } \\
\text { liv } \\
\text { liv }\end{array}$ & $\begin{array}{r}29 \\
23 \\
\\
\sim 25 \\
90 \\
90 \\
37 \\
15\end{array}$ & $\begin{array}{l}10 \mathrm{~h}=\max \\
\text { linear dose-dependence, } \\
\text { less after } \mathrm{ph} \\
\sim \text { kid <lun } \\
\text { also: fetal tissues, rli } \\
\text { various sites of label } \\
\text { compare mouse: } 25\end{array}$ & $\begin{array}{l}\text { Lawson [142] } \\
\text { Lawson [143] } \\
\text { Bhide [6] } \\
\text { Bhide [7] } \\
\text { Pound [208] } \\
\text { Prodi [213] } \\
\text { Bhide [6] }\end{array}$ \\
\hline Ethionine & $\mathbf{r}$ & $\begin{array}{l}\text { ip } \\
?\end{array}$ & $\begin{array}{l}18 \mathrm{~h} \\
12 \mathrm{~h}\end{array}$ & $\begin{array}{l}\text { liv } \\
\text { liv }\end{array}$ & $\begin{array}{l}0.2 \\
0.7\end{array}$ & & $\begin{array}{l}\text { Swann }[263] \\
\text { Rocchi }[221]\end{array}$ \\
\hline Acrolein & $\mathbf{r}$ & ip & $0.2-24 \mathrm{~h}$ & rli & 360 & stable & Munsch [183] \\
\hline
\end{tabular}

\subsection{Covalent binding to nucleic acids or protein in vitro}

In vitro binding studies with incubations of nucleic acids (class 4 ) or protein (class 5) with a test compound were positive for additional 20 and 22 chemicals, respectively. The metabolic activation to reactive derivatives was performed in most cases with mammalian liver microsomes. This type of test has predominantly chemical relevance and a relationship to tumorigenicity must remain very vague.

\subsection{Compounds for which no covalent binding to nucleic acids was found}

6 compounds have been tested for covalent binding in vivo to DNA but no binding was found. Two non-carcinogenic epoxides and benzo[ $e]$ pyrene were compared with chemically related, carcinogenic compounds in order to show the good quantitative correlation between carcinogenicity and DNA binding. Saccharin was studied on an absolute basis and the limit of detection of a Covalent Binding Index, CBI, for DNA of rat liver and bladder was 0.005 and 0.05 , resp. [158]. This is more than a million times below the effectiveness of binding of aflatoxin $B_{1}$ and reflects the lack of saccharin to undergo covalent interactions with DNA in vivo. The carcinogenicity of saccharin to the bladder of male rats (from the extremely high dosage of $5 \%$ in the diet) must therefore be due to an indirect, "epigenetic", mechanism and not to a covalent interaction with DNA. 


\section{TABLE 21}

IN VIVO BINDING OF CHEMICALS TO DNA. NO CALCULATION OF A 'CBI' POSSIBLE SULPHONATES, EPOXIDES, LACTONES, MUSTARDS, OTHER HALOGENATED COMPOUNDS See Table 13 for legend.

\begin{tabular}{|c|c|c|c|c|c|c|}
\hline Compound & $\mathbf{S}$ & $\mathbf{R}$ & Time & Org & Remarks & Reference \\
\hline $\begin{array}{l}\text { Methyl methane- } \\
\text { sulphonate }\end{array}$ & $\mathbf{r}$ & ip & $4 \mathrm{~h}$ & liv & pattern of methylations & Craddock [48] \\
\hline 1,2,3,4-Diepoxybutane & $\mathbf{m}$ & pt & $12 h=\max$ & ski & $\begin{array}{l}\text { no binding from two non- } \\
\text { carcinogenic epoxides }\end{array}$ & Paul [199] \\
\hline \multirow[t]{3}{*}{$\beta$-Propiolactone } & $\begin{array}{l}\mathbf{m} \\
\mathbf{m}\end{array}$ & $\begin{array}{l}\text { pt } \\
\text { pt }\end{array}$ & $\begin{array}{l}24 \mathrm{~h} \\
\text { divers }\end{array}$ & $\begin{array}{l}\text { ski } \\
\text { ski }\end{array}$ & $\begin{array}{l}\text { non-linear dose-response } \\
\text { with binding and tumors } \\
\text { (saturation kinetics) }\end{array}$ & $\begin{array}{l}\text { Brookes [24] } \\
\text { Colburn [35] }\end{array}$ \\
\hline & $\mathbf{m}$ & $\mathrm{pt}$ & divers & ski & $\begin{array}{l}\text { lower binding in resistant } \\
\text { strain }\end{array}$ & Colburn [36] \\
\hline & $\mathbf{m}$ & pt & $4 h=\max$ & ski & $\begin{array}{l}\text { DNA binding higher than } \\
\text { from compounds at bottom } \\
\text { of Table. Correlates with } \\
\text { tumor induction }\end{array}$ & Colburn [ 37] \\
\hline Nitrogen mustard & $\mathbf{m}$ & ip & $1 \mathrm{~h}$ & asc & linear dose-binding dep. & Chun [33] \\
\hline Sulphur mustard & $\begin{array}{l}\mathbf{m} \\
\mathbf{m}\end{array}$ & ip & $\begin{array}{l}0.5 \mathrm{~h} \\
4 \mathrm{~h}\end{array}$ & $\begin{array}{l}\text { asc } \\
\text { asc }\end{array}$ & & $\begin{array}{l}\text { Brookes }[20] \\
\text { Trams }[273]\end{array}$ \\
\hline Aniline mustard & $\mathrm{m}$ & ip & $\begin{array}{l}18 \mathrm{~h} \\
30 \mathrm{~h}\end{array}$ & $\begin{array}{l}\text { mye } \\
\text { asc }\end{array}$ & $\begin{array}{l}\text { correlation binding vs. } \\
\text { tumor inhibition } \\
\text { resistant = sensitive asc. }\end{array}$ & $\begin{array}{l}\text { Connors [38] } \\
\text { Poynter [209] }\end{array}$ \\
\hline $\begin{array}{l}\beta \text {-Naphthylamine } \\
\text { mustard }\end{array}$ & $\mathbf{m}$ & ip & $18 \mathrm{~h}=\max$ & mye & $\begin{array}{l}\text { correlation see above. } \\
\text { linear dose-binding dep. }\end{array}$ & Connors [38] \\
\hline Cyclophosphamide & $\mathbf{r}$ & ip & $2 h=\max$ & div & time-depend. fluctuations & Tew [270] \\
\hline Chlorambucil & $\mathbf{m}$ & ip & $0.1 \sim 4 h$ & asc & & Trams [273] \\
\hline Vinyl chloride & $\mathbf{r}$ & po & chronic & liv & after 2-year feeding & Green [82] \\
\hline Iodoacetic acid & $\mathrm{m}$ & pt & $4 h=\max$ & ski & $\begin{array}{l}<<\text { protein binding; com- } \\
\text { pare: } \beta \text {-propiolactone }\end{array}$ & Colburn [37] \\
\hline 3-Chloropropionic acid & $\mathbf{m}$ & pt & $4 h=\max$ & ski & $\begin{array}{l}<<\text { protein binding; com- } \\
\text { pare: } \beta \text {-propiolactone }\end{array}$ & Colburn [37] \\
\hline 3-Iodopropionic acid & $\mathbf{m}$ & pt & $4 h=\max$ & ski & $\begin{array}{l}<<\text { protein binding; com- } \\
\text { pare: } \beta \text {-propiolactone }\end{array}$ & Colburn [37] \\
\hline
\end{tabular}

\section{Correlation of carcinogenicity with DNA binding}

\subsection{Quantitative correlation of CBI for liver DNA with hepatocarcinogenicity} For the reasons outlined in section 2.3, Covalent Binding Indices, CBI, have been determined mostly for the liver not only from hepatocarcinogens but also from compounds which do not induce liver tumors.

In this section, hepatocarcinogens are taken together and a correlation of their carcinogenic potency with CBI for liver DNA is discussed.

A classification according to carcinogenic potency is currently being attempted in many laboratories [175]. Ames and coworkers have announced a complete literature survey of long-term carcinogenicity assays in order to calculate for each carcinogen a so-called TD-50, i.e., the daily dose needed to induce 
TABLE 22

IN VIVO BINDING OF CHEMICALS TO DNA. NO CALCULATION OF A 'CBI' POSSIBLE AROMATIC HYDROCARBONS

See Table 13 for legend.

\begin{tabular}{|c|c|c|c|c|c|c|}
\hline Compound & $\mathbf{s}$ & $\mathbf{R}$ & Time & Org & Remarks & Reference \\
\hline Anthracene & $\mathbf{r}$ & & $20 \mathrm{~h}$ & mam & injection into mam gland & Lin [153] \\
\hline Benz $[a]$ anthracene & $\mathbf{m}$ & pt & $28 \mathrm{~h}$ & ski & & Brookes [24] \\
\hline Diben $\approx[a, c]$ anthracene & $\mathbf{m}$ & $\begin{array}{l}\text { pt } \\
\text { pt } \\
\text { pt }\end{array}$ & $\begin{array}{l}24 h \\
24 h=\max \\
50 h=\max \end{array}$ & $\begin{array}{l}\text { ski } \\
\text { ski } \\
\text { ski }\end{array}$ & $\begin{array}{l}=[a, h] \text {-derivative } \\
\text { no correl. with carcinog. } \\
<[a, h] \text {-derivative } \\
\text { correl. with carcinog. }\end{array}$ & $\begin{array}{l}\text { Heidelberger [90] } \\
\text { Brookes [21] } \\
\text { Goshman [79] }\end{array}$ \\
\hline Dibenz $[a, h]$ anthracene & $\begin{array}{l}\mathrm{m} \\
\mathrm{m} \\
\mathrm{m} \\
\mathrm{m}\end{array}$ & $\begin{array}{l}\text { pt } \\
\text { pt } \\
\text { pt } \\
\text { pt }\end{array}$ & $\begin{array}{l}24 h \\
24 h=\max \\
40 h=\max \\
24 h\end{array}$ & $\begin{array}{l}\text { ski } \\
\text { ski } \\
\text { ski } \\
\text { ski }\end{array}$ & $\begin{array}{l}\text { see above } \\
\text { see above } \\
\text { syn/antag. with } 7,8-\mathrm{BF} \text {, } \\
5,6-\mathrm{BF}, \mathrm{PB} \text { (chapter 5) }\end{array}$ & $\begin{array}{l}\text { Heidelberger [90] } \\
\text { Brookes [21] } \\
\text { Goshman [79] } \\
\text { Bowden [15] }\end{array}$ \\
\hline Benzo $[a]$ pyrene & $\mathbf{m}$ & pt & $24 \mathrm{~h}=\max$ & ski & & Brookes $[21]$ \\
\hline \multirow[t]{2}{*}{$\begin{array}{l}\text { 7.12-Dimethyl- } \\
\text { benz }[a] \text { anthracene }\end{array}$} & $\begin{array}{l}\mathbf{m} \\
\mathbf{m} \\
\mathbf{m}\end{array}$ & $\begin{array}{l}\text { pt } \\
\text { pt } \\
\text { pt }\end{array}$ & $\begin{array}{l}22 \mathrm{~h}=\max \\
24 \mathrm{~h} \\
24 \mathrm{~h}\end{array}$ & $\begin{array}{l}\text { ski } \\
\text { ski } \\
\text { ski }\end{array}$ & $\begin{array}{l}\text { equal bind, to satellite } \\
\text { or main band DNA }\end{array}$ & $\begin{array}{l}\text { Brookes [21] } \\
\text { Goshman [79] } \\
\text { Zeiger [295] }\end{array}$ \\
\hline & $\mathbf{m}$ & pt & $\begin{array}{l}8 \mathrm{~h} \\
24 \mathrm{~h} \\
20 \mathrm{~h}\end{array}$ & $\begin{array}{l}\text { ski } \\
\text { ski } \\
\text { mam }\end{array}$ & $\begin{array}{l}\text { DNA adduct as template } \\
\text { syn/antag. with } 7,8-\mathrm{BF} \text {, } \\
5,6-\mathrm{BF} \text {, PB (chapter } 5 \text { ) } \\
\text { injection into mam gland }\end{array}$ & $\begin{array}{l}\text { Bowden [13] } \\
\text { Bowden [14] } \\
\text { Bowden [15] }\end{array}$ \\
\hline 3-Methylcholanthrene & $\mathbf{m}$ & $\begin{array}{l}\text { pt } \\
\text { pt }\end{array}$ & $24 h$ & $\begin{array}{l}\text { ski } \\
\text { ski }\end{array}$ & & $\begin{array}{l}\text { Brookes [21] } \\
\text { Goshman [79] }\end{array}$ \\
\hline
\end{tabular}

a specific tumor in $50 \%$ of the animals treated for life. Because of the immense experimental variety of long-term bioassays this is a very demanding task, especially where an extrapolation is required from a few weeks' feeding study to life-long feeding. The TD-50 values span over more than 6 orders of magnitude from aflatoxin $B_{1}(1 \mu \mathrm{g} / \mathrm{kg}$ and day) to trichloroethylene $(1 \mathrm{~g} / \mathrm{kg}$ and day $)$ or saccharin $(>5 \mathrm{~g} / \mathrm{kg}$ and day). The use of such high doses is very questionable anyway since (i), an impurity might be responsible for the tumors observed, and (ii), the overload of an animal with one compound might lead to secondary changes finally responsible for the development of a tumor.

In Table 26, we have grouped the hepatocarcinogens into 3 classes according to very rough classification on the basis of data available in the "Monographs on the evaluation of carcinogenic risk of chemicals to man" of the International Agency for the Research on Cancer, Lyon, France. As soon as Ames's TD-50 data are available a more refined classification might be possible. The CBI were selected from Tables 13-20, and a maximum value was chosen if a time-dependent study was available. A striking quantitative correlation between DNA binding and hepatocarcinogenicity is seen with these representatives of many different chemical classes. It emerges that a CBI in the thousands represents the strong hepatocarcinogens, a CBI in the hundreds represents the moder- 
TABLE 23

IN VIVO BINDING OF CHEMICALS TO DNA. NO CALCULATION OF A 'CBI' POSSIBLE

AMINES, HYDR AZINES, AZOXY-, AND NITRO-DERIVATIVES, TRIAZENES

See Table 13 for legend.

\begin{tabular}{|c|c|c|c|c|c|c|}
\hline Compound & $\mathbf{S}$ & $\mathbf{R}$ & Time & Org & Remarks & Reference \\
\hline 2-Naphthylamine & $\mathbf{m}$ & ip & $24 \mathrm{~h} \sim 7 \mathrm{~d}$ & liv & $\begin{array}{l}\text { > kid: correlation with } \\
\text { strain susceptibility }\end{array}$ & Hughes $[97]$ \\
\hline 2-Acetylaminofluorene & $r$ & ip & chronic & mam & no increase beyond $2 \mathrm{w}$ & Janss [110] \\
\hline $\begin{array}{l}\text { 4-Dimeth ylaminoazo- } \\
\text { benzene }\end{array}$ & $\mathbf{r}$ & po & & liv & $1-3 w$ in the diet & Chauveau [31] \\
\hline $\begin{array}{l}\text { 2-Methyl-4-dimethyl- } \\
\text { aminoazobenzene }\end{array}$ & $\mathbf{r}$ & po & & liv & $\begin{array}{l}1-3 \mathrm{w} \text { in the diet } \\
\text { correlation of tumor for- } \\
\text { mation with DNA-binding. } \\
\text { not protein }\end{array}$ & Chauveau [31] \\
\hline \multirow[t]{2}{*}{ 1,2-Dimethylhy drazine } & $\mathbf{r}$ & sc & $\mathbf{3} \mathbf{h}$ & liv & $\begin{array}{l}\text { >other organs, } O(6) / N-7- \\
\text { guanine methylation higher } \\
\text { in col than liv }\end{array}$ & Likhachev [150] \\
\hline & $\mathbf{m}$ & sc & $6 / 24 \mathrm{~h}$ & liv, col & 7-methylguanine detected & Hawks [87] \\
\hline Cycasin & $\mathbf{r}$ & po & $10 \mathrm{~h}$ & liv & $\begin{array}{l}\text { non-radioactive; } 7 \text {-methyl- } \\
\text { guanine identif. }\end{array}$ & Shank $[240]$ \\
\hline $\begin{array}{l}\text { Methy lazoxymethanol } \\
\text { acetate }\end{array}$ & $\mathbf{r}$ & po & $5-10 h$ & liv & $\begin{array}{l}\text { 7-meth ylguanine identif.; } \\
\text { also kid, int }\end{array}$ & Shank [240] \\
\hline $\begin{array}{l}\text { 4-Nitro-quinoline-1- } \\
\quad \text { oxide }\end{array}$ & $\mathbf{m}$ & ip & $1-32 \mathrm{~h}$ & asc & $4 \mathrm{~h}=\max$ & Ikegami [99] \\
\hline $\begin{array}{l}\text { 4-Hydrox yamino- } \\
\text { quinoline-1-oxide }\end{array}$ & $\mathbf{r}$ & ip & $1 \mathrm{~h}$ & asc & & Tada [269] \\
\hline $\begin{array}{l}\text { 1-Nitro-9-( } 3^{\prime} \text {-dimethyl- } \\
\text { n-propylamino })- \\
\text { acridine }\end{array}$ & $\mathrm{m}$ & ip & $4 h=\max$ & asc & & Konopa [124] \\
\hline Dacarbazine (DIC) & $\mathbf{r}$ & ip & $5 \mathrm{~h}$ & liv & $\begin{array}{l}\text { also: lun, kid, bra. } \\
\text { DN A-methylations }\end{array}$ & Skibba [247] \\
\hline
\end{tabular}

ate, and a $\mathrm{CBI}$ in the tens the weak hepatocarcinogens. The limit of detection of a binding to liver DNA has been discussed in section 2.2, and saccharin, a clearly non-hepatocarcinogenic compound is more than a million times less effective than the strong hepatocarcinogens. Such a range of 6 orders of magnitude was also found with the TD-50 values which is a nice indication that CBI and carcinogenicity could be quantitatively related.

Among the chemicals chosen for Table 26 is aflatoxin $M_{1}$, for which only rare information is available on carcinogenicity. Aflatoxin $M_{1}$ is a metabolite of the potent hepatocarcinogen aflatoxin $B_{1}$, and is secreted to an appreciable amount in the milk of cows which have been fed aflatoxin $B_{1}$-containing diets. Our preliminary binding studies have revealed a CBI of more than one thousand so that aflatoxin $M_{1}$ must be regarded as a strong hepatocarcinogen. Special care should therefore be exerted with aflatoxin contaminations of the feed for milk cows.

Aflatoxin $B_{1}$ contaminations in the feed for meat production represent the different problem of potential residues in meat. It has been found that a con- 
TABLE 24

IN VIVO BINDING OF CHEMICALS TO DNA. NO CALCULATION OF A 'CBI' POSSIBLE N-NITROSO-COMPOUNDS

See Table 13 for legend.

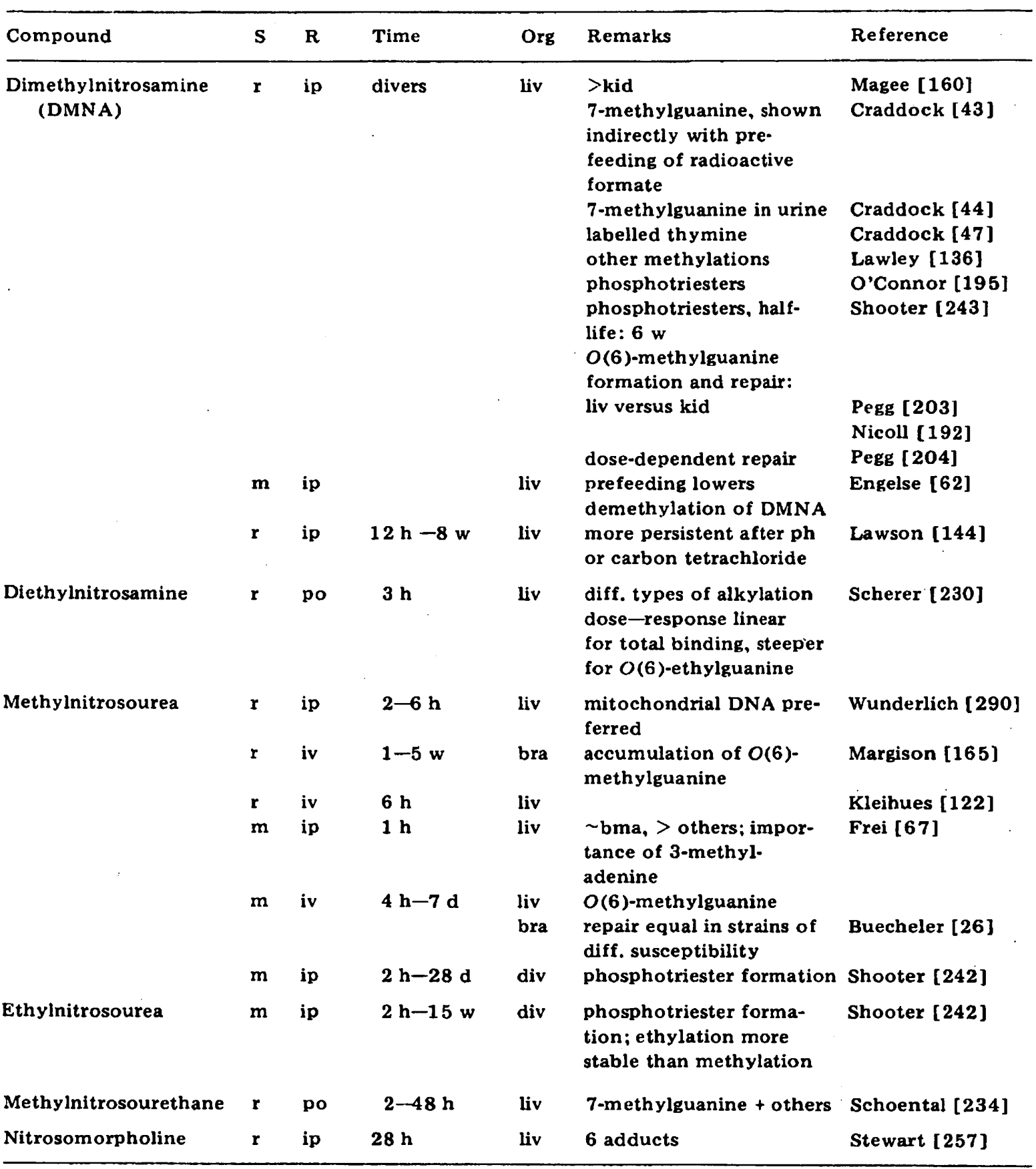

siderable fraction of an oral dose of aflatoxin $B_{1}$ is covalently bound to macromolecules of the liver of pigs [Lüthy, in preparation]. If this liver is consumed by humans the covalently bound aflatoxin derivative might be cleaved from its macromolecule in the gastro-intestinal system. It could then be absorbed and undergo a second interaction with DNA or other macromolecules of the liver or other organs. 


\section{TABLE 25}

IN VIVO BINDING OF CHEMICALS TO DNA. NO CALCULATION OF A 'CBI' POSSIBLE OTHER CLASSES OF COMPOUNDS

See Table 13 for legend.

\begin{tabular}{lllllll}
\hline Compound & S & R & Time & Org & Remarks & Reference \\
\hline Ethionine & r & ip & $20 \mathrm{~h}$ & $\begin{array}{l}\text { 2 doses } \\
\text { abstract } \\
\text { abstract; 7-ethylguanine in } \\
\text { all species } \\
\text { abstract; 7-ethylguanine in } \\
\text { all species }\end{array}$ & $\begin{array}{l}\text { Farber [65] } \\
\text { Cox [41] }\end{array}$ & Cox [41] \\
& m & $24 \mathrm{~h}$ & $\begin{array}{l}\text { abstract: 7-ethylguanine in } \\
\text { all species } \\
\text { model compound for afla- }\end{array}$ & Cox [41] \\
$\begin{array}{c}\text { 2-(N-Ethyl-carbamoyl- } \\
\text { hydroxymethyl)furan }\end{array}$ & r & ip & $24 \mathrm{~h}$ & $\begin{array}{l}\text { liv } \\
\text { loxins }\end{array}$ & Guengerich [85] \\
\hline
\end{tabular}

It would be very important to know the effectiveness of covalent DNA binding of such bound aflatoxin derivatives. We have performed some preliminary experiments on this type of "relay" toxicity. Two sponsor rats were orally administered about $5 \mu \mathrm{Ci}$ [C-14] aflatoxin $\mathrm{B}_{1}$ each. After $6 \mathrm{~h}$, their livers were homogenized, centrifuged, dialyzed, and extracted with methylene chloride. The dry residue containing about $800000 \mathrm{dpm}$ macromolecule-bound aflatoxin was resuspended in methylcellulose and administered orally to another rat for a

TABLE 26

CORRELATION OF HEPATOCARCINOGENICITY OF CHEMICALS IN THE RAT WITH THE COVALENT BINDING INDEX, CBI, FOR RAT-LIVER DNA

The data are selected from Tables $13-20$ where also the references can be found. A range of CBI is given where similar experiments yielded widely scattering data.

\begin{tabular}{lc}
\hline Compound & Range of CBI \\
\hline Strong hepatocarcinogens & 17000 \\
Aflatoxin B1 & 1600 \\
Aflatoxin M1 & 6000 \\
Dimethylnitrosamine & $42-430$ \\
Diethylnitrosamine & \\
Moderate hepatocarcinogens & 560 \\
Aflatoxin B2 & 560 \\
2-Acetylaminofluorene & 525 \\
Vinyl chloride & 230 \\
o-Aminoazotoluene & 180 \\
Nitrosopyrolidine & 120 \\
Nitrosopiperidine & 44 \\
Nitrosomorpholine & \\
Weah hepatocarcinogens & $29-90$ \\
Urethane & 6 \\
4-Dimethylaminoazobenzene & 2 \\
p-Aminoazobenzene & 1 \\
Ethionine & \\
Non-hepatocarcinogen & $<0.005$ \\
Saccharin &
\end{tabular}


standard determination of the CBI for liver DNA. No radioactivity was measurable on the liver DNA of this second rat and the highest possible CBI was calculated to be about 75 as compared with 10000 for aflatoxin $B_{1}$. The corresponding limit of detection of a CBI for rat-liver DNA with tritiated aflatoxin $B_{1}$ was 2.3. It can, at this stage, be concluded that macromolecule-bound aflatoxin has a much lower, if any, effectiveness of DNA binding.

It is evident from Table 26 that CBI and carcinogenicity correlate only semiquantitatively. Diethylnitrosamine is too carcinogenic for its relatively low CBI. Nitrosomorpholine is also too carcinogenic for its CBI. Vinyl chloride, on the other hand, seems to have a too high CBI as compared with 2-acetylaminofluorene. The weak hepatocarcinogen 4-dimethylaminoazobenzene has a single digit CBI which is also obtained from many other chemicals that do not induce liver tumors after: similar treatments (benzo[a]pyrene, 3-methylcholanthrene, Table 14).

This overlapping between the classes can be due to a number of causes, either resulting from insufficient long-term carcinogenicity data or from problems with the DNA-binding experiments. Only the latter will be discussed here.

The CBI calculated from the literature data could be too high if only total radioactivity on the DNA was available without appropriate control data on biosynthetic incorporation of radioactivity (urethane?) or if the DNA was highly contaminated with protein.

On the other hand, the CBI could be too low if the adduct formed is chemically unstable and partly breaks down during the DNA-isolation procedure.

The dose used for a binding experiment was too high so that saturation processes and non-linear dose-binding relationships resulted.

All these factors could reduce the experimental accuracy in the calculation of a CBI from the literature. Fortunately, the range of CBI covers about 6 orders of magnitude and a correlation of CBI to carcinogenic potency can be based roughly upon the order of magnitude so that minor experimental deviations do not render a quantification impossible. More important may be that the biological sequence of events between DNA binding and tumor is not the same for all bound carcinogens. The most important factors are: various patterns of DNA-binding sites, different activities of DNA repair, different mutagenicities of a specific type of DNA damage.

\section{2. $C B I$ and organotropy}

\subsubsection{Non-hepatocarcinogens and their CBI for liver DNA}

There are physiological compounds which have the biochemical potential to undergo a covalent binding to DNA in vivo but which are not called carcinogens. Estrone (Table 20), for example, has a "Covalent Binding Index" like benzene or like the synthetic hormone analogue ethinylestradiol.

The fact that benzene and ethinylestradiol have similar CBI should not be misinterpreted. The CBI was defined as DNA binding per unit dose and it should always be borne in mind that the actual dose must also be accounted for when a carcinogenic risk has to be assessed.

It was shown in the last section that a surprisingly good semi-quantitative correlation exists between hepatocarcinogenicity and CBI for liver DNA. 
Similarly, non-hepatocarcinogens would not be expected to bind readily to liver DNA. Unfortunately, there are many examples where a CBI for liver DNA in the tens or even hundreds is found from chemicals which do not induce liver tumors.

One main group of such false-positive compounds comprises of the directly alkylating chemicals like the sulphonates which strongly alkylate liver DNA without being hepatocarcinogenic (Table 13). Some nitroso derivatives that do not require metabolic activation either, like methylnitrosourea or $N$-methyl$N^{\prime}$-nitro- $N$-nitrosoguanidine (Table 18), belong to the same category. One reason for this discrepancy is the fact that binding data are predominantly from parenteral administrations whereas life-long carcinogenicity studies are performed with oral intake. The chemicals described above decompose and alkylate according to their chemical stability primarily at the site of administration, which is the oral and intestinal area in long-term studies but is the intraperitoneal cavity and the liver with i.p. injections.

This local effectiveness of binding does not, however, explain all discrepancies because many of these methylating agents give rise to tumors of the nervous system and of lymphatic tissue which are not at the site of administration in either carcinogenicity or binding experiment. Furthermore, organotropic carcinogens that require metabolic activation can yield higher DNA binding in liver than in the target organ. One example for such behaviour is 1,2-dimethylhydrazine which gives rise to $6 \times$ less binding in the colon, the target organ, as compared to liver (Table 17).

Biological reasons must therefore also be sought to explain the lack of correlation mentioned. Some of them are discussed in later sections of this chapter.

The too high CBI for liver DNA from this type of carcinogen also has positive aspects: These compounds are moderate or even strong carcinogens! Not for liver, as might be expected from the relatively high CBI, but for other organs. It could therefore even be argued that the carcinogenic potency of a chemical could be assessed from the binding to liver DNA regardless of the target organ. This way of thinking diminishes the biological foundation for accepting DNA binding as a prerequisite in chemical carcinogenesis but it strongly enhances its value as a short-term test with quantitative predictions but without a value for organotropy.

\subsubsection{CBI for other organs versus carcinogenic organotropy}

As a consequence of what has been said above, the CBI for DNA of the target organ is not always higher than that of the liver. Nevertheless, some carcinogens which are not hepatocarcinogenic do have high CBI values in the target organ.

Dimethylsulphate (Table 13) yields the highest DNA methylation in brain and lung which correlates with the incidence of tumors. Benzo [ $a]$ pyrene (Table 14) gives a higher DNA binding in mouse skin than in liver even after oral administration. 7,12-Dimethylbenz [ $a$ ] anthracene which gives mostly mammary tumors has indeed a much higher $\mathrm{CBI}$ in the mammary gland compared to that of liver (Table 14). This compound is also known to induce nervous-system tumors in the offspring of rats treated at the end of gestation. DNA binding in 
the brain was indeed more than twice as high in the fetus as compared to the pregnant mother, whereas the DNA binding in liver or intestine was higher in the mother [57]. The bladder carcinogen $o$-aminoazotoluene (Table 16) gives rise to the highest CBI for DNA of the bladder.

To summarize, the organotropy of carcinogens can be reflected in higher DNA binding in the target organ but this is not a general rule. The following refinements of a DNA-binding assay must therefore be included if this aspect of chemical carcinogenicity is to be studied more deeply.

\subsection{Refinements in the measurement of DNA binding for an improved quan- titative correlation with carcinogenicity}

\subsubsection{Pattern of DNA-binding sites}

More than 10 sites of attack on nucleic acids by alkylating agents have been detected in recent studies. The formation of some of these products was shown not to correlate with carcinogenesis [reviewed in 202]. These included the major product of the reaction, 7-alkylguanine, so that it is not astonishing that the measurement of total binding to DNA cannot correlate quantitatively with tumor incidence in the class of methylating and ethylating carcinogens. The other, more critical products include phosphotriesters, 3-alkylguanine, $O(4)$ alkylthymine, 7 -alkyladenine, and $O(6)$-alkylguanine. This last product has been shown to be responsible for mispairing $[73,155]$, and a number of investigations with $N$-nitroso compounds have revealed that organs which readily develop tumors are much less active in the removal of $O(6)$-alkylguanine from their DNA than non-target organs $[122,138,192,200,201,203]$.

The relative abundance of all these DNA adducts depends upon the type of chemical reactivity of the ultimate carcinogen. The $N$-nitroso compounds yield positively charged alkyl ions (Fig. 2), i.e. electrophiles which do not strongly discriminate among the nucleophilicity of their target atoms $\left(\mathrm{S}_{\mathrm{N}} 1\right.$-type reactivity). The sulphonates, epoxides, mustards, and other directly alkylating carcinogens (Fig. 2), react according to an $\mathrm{S}_{\mathrm{N}} 2$ reaction profile where the nucleophilic atom on the DNA is actively involved in the attack on the carcinogen. Since the N-7 of guanine is the most nucleophilic center, this latter type of reactivity leads predominantly to 7-alkylguanine and comparatively small amounts of other DNA damage. With the $\mathrm{S}_{\mathrm{N}} 1$ reactive carcinogens, 7-alkylation of guanine is still most abundant but the fraction of other positions becomes more important.

On the basis of this knowledge it is no longer surprising to see that methyl methanesulphonate (Table 13) and methylnitrosourea (Table 18) lead to about the same degree of total DNA methylation in many organs but that the $\mathrm{S}_{\mathrm{N}} 1$ reactive nitroso compound gives rise to more tumors, most probably due to a higher percentage of methylations at more critical sites than from the $\mathrm{S}_{\mathrm{N}} 2$ reactive sulphonate.

For other carcinogens with sterically larger ultimate derivatives, 7-alkylation of guanine should have more serious consequences than have methylations or ethylations. The main DNA adduct with aflatoxin $B_{1}$, for example, is also a 7-guanine derivative [152] and it is probable that this position has some importance for the carcinogenic response. This could be due to the fact that large 
attachments to the double helix interfere not only with the hydrogen bonding but also with the tertiary structure. This might be the reason why that surprisingly good quantitative correlation between DNA binding and hepatocarcinogenicity was found with all carcinogens except the small alkylating chemicals. Another reason for the usefulness of measuring total binding lies in the fact that some well-studied carcinogens do not at all prefer 7-alkylation of guanine but lead to very specific DNA-binding patterns.

Aromatic amines were among the first carcinogens for which $\mathrm{C}-8$ of guanine was an established DNA-binding site [reviewed in 178]. More recent findings suggest that the persistently bound form of 2-acetylaminofluorene results from a reaction with the $N(2)$-amino group of DNA guanine [ 283 and refs. therein]. This amino group seems to be the target also for the ultimate carcinogen of benzo[a]pyrene [125, and refs. therein].

4.3.2. DNA repair as an organotropic modulating factor in chemical carcinogenesis. Persistence of DNA binding

Enzymatic repair of DNA after damage by physical or chemical means has been the object of many studies and has also been reviewed [34,146,250]. DNA repair is probably one of the most important factors that protects us from the consequences of a never-ceasing attack of damaging agents on DNA. In a number of recessively inherited human disorders, the affected individuals are cancer-prone. 3 of these are associated with defects in the ability of cells to repair certain kinds of physical or chemical damage to their DNA [239].

From a number of experiments it is now clear that such repair activities can also excise stretches of a DNA strand which contains a nucleotide to which is bound an ultimate carcinogen. The following characteristics are quickly summarized [refs. in the first paragraph of section 4.3.1].

1. Not all types of DNA damage are repaired enzymatically or are repaired equally well.

2. The efficiency of a specific type of repair differs between organs. Slow repair correlates with a higher susceptibility of that organ to tumor formation from exposure to the agent responsible for that damage.

3. Repair activity can be saturated either by a high dose of an alkylating agent or by simultaneous administration of more than one alkylating agent, not necessarily of the same type.

Such DNA repair can be measured on the basis of unscheduled DNA synthesis, but this is possible only with cells in culture where the inhibition of DNA replication with hydroxyurea or other compounds is feasible. In intact mammalian organs, this approach was so far not successful, and only repair of strand breaks can be followed in vivo with DNA-sedimentation analysis. On the other hand, a time-dependent observation of DNA binding could be used as a measure for repair activity, if the appropriate control experiments are performed (2.4).

The time-dependence of DNA binding reveals striking differences in the persistence of the label in different organs. There is strong evidence that the target organ has a slow repair activity for a specific type of damage. For example, DNA binding by 7,12-dimethylbenz[a]anthracene (Table 14) in the target organ, the mammary gland, decreases only to one third of the maximum level 
within 6 weeks, whereas in the liver, which is not a target organ under such conditions, no binding can be detected anymore at that time.

Especially well known is the persistence of aromatic amines on liver DNA. 2-Acetylaminofluorene (Table 15) has an almost constant level of binding between day 1 and 3,4-dimethylaminoazobenzene (Table 16) gives rise to persistent binding for even 3 months, $o$-aminoazotoluene (Table 16) has been found bound to liver DNA for almost 3 months.

As was found in the correlation of hepatocarcinogenicity to DNA binding in liver (Table 26), the carcinogenic potency of these aromatic amines and azo derivatives of aromatic amines is relatively high for their CBI. This is most probably due to the observed persistence of the DNA-bound molecules which is a sign of inefficient repair of that specific type of damage in liver DNA.

The repair activities are therefore not only different in various organs but are different also with respect to the various types of DNA damage. This persistence of some types of DNA damage is astonishing in the light of the experimental fact that repair enzymes can detect conformational disturbances in the double helix and cut out tens of base pairs on each side of the damage. It could therefore well be speculated that these persistently bound carcinogens do not have only one bond to the DNA but additional, perhaps cross-linking activity. Such a double interaction can only be performed with big enough molecules with either a second potentially reactive group or a polycyclic system.

\subsection{Mutagenicity of a specific type of DNA damage}

If DNA with covalently bound carcinogen is replicated or transcribed the probability for a base substitution, deletion, or insertion to occur will depend both upon the exact site of adduct formation as well as on the structure of the bound chemical. If one compares a methylating agent with its ethylating analogue it is seen that the carcinogenic potencies are similar but that the CBI vary by more than an order of magnitude. This discrepancy could arise either from less efficient repair of DNA ethylations (section 4.3.2) or from the possibility that the ethylated DNA gives rise to more mutations upon replication than a DNA which is methylated.

For a refined assessment of the carcinogenic potential of a chemical on the basis of DNA binding it would therefore be necessary to study the mutagenicity of a specific type of DNA damage. Some experimental evidence is available for mispairing with $O(6)$-methylguanine (section 4.3.1) but there is still a considerable lack of information on the mutagenic effectiveness of larger carcinogens bound to DNA.

Only few reports are so far available where mutagenic events and DNA binding have been studied in the same experimental system. In the first report [236] the ethylation of DNA of Drosophila sperm cells was measured and correlated with previously published reports on sex-linked recessive lethals obtained after exposure to ethyl methanesulphonate (EMS). A similar study was reported two years later [237] where DNA ethylation of mouse spermatozoa was measured and discussed with respect to dominant lethal studies by other investigators.

Both these studies were pioneering and smoothed the way for additional work with more elaborate treatment schedules and more appropriate concen- 
trations of EMS exposure. With these improvements, a linear relationship between ethylation of Drosophila sperm DNA and sex-linked recessive lethals was found in a wide dose range and no threshold was apparent [1].

The mouse system was also refined and it was found that the ethylations per sperm head closely paralleled the dominant lethal frequency curve for EMS [238]. Besides these germ-line studies, only two reports are available with bacteria or cells in culture.

In the first one, benzo[a]pyrene and 7-methylbenz $[a]$ anthracene were used to mutate Chinese hamster cells, and the binding to cellular DNA was measured simultaneously [191]. The results showed that both carcinogens were almost equally mutagenic per corrected micromole per mole nucleotides and it was suggested that the difference in carcinogenicity between the two hydrocarbons is a consequence of the extent rather than the nature of their reaction with DNA.

A number of studies have shown that the Ames Test cannot be used for a quantification of carcinogenic potential (section 1.2) and it was shown that the main problem lies in the activation of the carcinogens to chemically reactive derivatives. For instance, 7,12-dimethylbenz [ $a$ ]anthracene (DMBA) is a more potent carcinogen than benzo $[a]$ pyrene $(\mathrm{BP})$ and is bound to a higher extent to DNA in the target tissue, mouse skin (Table 22), as well as in rat liver (Table 14). In contrast to this correlation, the mutagenic activity of DMBA in the Ames Test is only about a sixth of that of BP [172]. This discrepancy could be explained if the binding of DMBA to the Salmonella DNA was lower than that of BP.

In preliminary experiments [164] we have incubated Salmonella in liquid phase with the two radiolabelled carcinogens in the presence of rat-liver $9000 \mathrm{X}$ $g$ supernatant. Aliquots were plated and scored for revertants and the bulk incubation mixture was used for the isolation of Salmonella DNA and the determination of the amount of bound carcinogen. In agreement with Ames's data, the mutagenic activity of DMBA was lower than that of BP, and the same order was found for the binding to DNA. The low mutagenic potency of DMBA is therefore due to low DNA binding, probably because the metabolic pathways in the mutagenicity test system are different from those in a mammalian organ. On the basis of the present results it cannot be decided yet, whether the damage produced by DMBA or BP is equally mutagenic because the mutagenicity results scattered widely.

The experiments described in this section correlate total DNA binding to mutagenicity. Obviously, the reservation made on the importance of the pattern of DNA binding holds not only for carcinogenic response but also for mutagenicity (see section 4.3.1). It will therefore be important to analyse the DNA on a nucleotide level in order to compare the mutagenicities of specific DNA adducts with each other. If this can be achieved, a big step towards the quantification of carcinogenic potency of chemicals will have been taken. 
5. Modulations of the carcinogenic response that can be studied on the basis of DNA binding

\subsection{Pretreatments and their influence on DNA binding in vivo and carcino. genicity}

An appreciable number of reports are available on synergisms and antagonisms in chemical carcinogenesis [reviews $64,232,281$; nutritional influences: 292]. Much less is known about the influence of a pretreatment on DNA binding in vivo.

\section{TABLE 27}

EFFECT OF PRETREATMENT OF ANIMALS ON IN VIVO DNA BINDING AND TUMOR FORMATION FROM EXPOSURE TO CHEMICAL CARCINOGENS

$\mathrm{Sp}=$ Species; $\quad r=$ rat, $\mathrm{m}=$ mouse

Tum $=$ Tumor $;$ liv $=$ liver, ski $=$ skin, fsto $=$ forestomach, $\sim=$ slightly, kid $=$ kidney, col $=$ colon, div $=$ divers.

\begin{tabular}{|c|c|c|c|c|c|c|}
\hline Carcinogen & $\mathrm{Sp}$ & Tum & Pretreutment & $\begin{array}{l}\text { Effect o } \\
\text { Tumor }\end{array}$ & Binding & Reference \\
\hline Dibenz $[a, h]$ anthracene & $\mathbf{m}$ & ski & $\begin{array}{l}\text { phenobarbital } \\
\text { 5,6-benzoflavone } \\
\text { 7,8-benzoflavone }\end{array}$ & $\begin{array}{l}\text { lower } \\
\text { lower } \\
\text { higher }\end{array}$ & $\begin{array}{l}\text { equal } \\
\text { lower } \\
\text { equal }\end{array}$ & $\begin{array}{l}\text { Bowden [15] } \\
\text { Bowden [15] } \\
\text { Bowden [15] }\end{array}$ \\
\hline $\begin{array}{l}\text { Benzo [a]pyrene } \\
\text { 7,12-Dimethylbenz- } \\
\text { [a] anthracene }\end{array}$ & $\mathbf{m}$ & $\begin{array}{l}\text { fsto } \\
\text { ski }\end{array}$ & $\begin{array}{l}\text { disulfiram } \\
\text { phenobarbital } \\
5,6 \text {-benzoflavone } \\
7,8 \text {-benzoflavone }\end{array}$ & $\begin{array}{l}\text { lower } \\
\text { lower } \\
\text { lower } \\
\text { lower }\end{array}$ & $\begin{array}{l}\text { lower } \\
\sim \text { lower } \\
\sim \text { lower } \\
\text { lower }\end{array}$ & $\begin{array}{l}\text { Borchert [12] } \\
\text { Bowden [15] } \\
\text { Bowden [15] } \\
\text { Bowden [15] }\end{array}$ \\
\hline $\begin{array}{l}\text { 2-Acetylamino- } \\
\text { fluorene }\end{array}$ & $\mathbf{r}$ & liv & $\begin{array}{l}\text { phenobarbital } \\
\text { 3-methylcholanthrene } \\
\text { special grain diet } \\
\text { butylated hydroxy toluene } \\
\text { chloramphenicol } \\
\text { acetanilide } \\
\text { m-acetotoluidide } \\
\text { indole }\end{array}$ & $\begin{array}{l}\text { lower } \\
\text { lower } \\
\text { lower } \\
\text { lower } \\
\text { higher } \\
\text { lower } \\
\text { lower } \\
\text { lower } \\
\text { lower } \\
\text { lower } \\
\text { no such }\end{array}$ & $\begin{array}{l}\text { lower } \\
\text { lower } \\
\text { lower } \\
\text { lower } \\
\text { higher } \\
\text { lower } \\
\text { lower } \\
\text { lower } \\
\text { lower } \\
\text { lower } \\
\text { correlatior }\end{array}$ & $\begin{array}{l}\text { Matsushima [170] } \\
\text { Mushlin [184] } \\
\text { Irving [102] } \\
\text { McGregor [174] } \\
\text { Irving [102] } \\
\text { Goodman [78] } \\
\text { Matsushima [169] } \\
\text { Matsushima [169] } \\
\text { Matsushima [169] } \\
\text { Matsushima [169] } \\
\text { with protein }\end{array}$ \\
\hline $\begin{array}{l}\text { 4-Dimethylamino- } \\
\text { azobenzene }\end{array}$ & $\mathbf{r}$ & liv & $\begin{array}{l}\text { phenobarbital } \\
\text { 3-methylcholanthrene ip } \\
\text { 3-methylcholanthrene diet } \\
\text { high riboflavin diet }\end{array}$ & $\begin{array}{l}\text { lower } \\
\text { lower } \\
\text { lower } \\
\text { lower }\end{array}$ & $\begin{array}{l}\text { lower } \\
\text { higher } \\
\text { equal } \\
\text { lower }\end{array}$ & $\begin{array}{l}\text { Decloitre [53] } \\
\text { Decloitre [53] } \\
\text { Decloitre [53] } \\
\text { Dingman [55] }\end{array}$ \\
\hline $\begin{array}{l}\text { 1,2-Dimethyl- } \\
\text { hydrazine }\end{array}$ & $\mathbf{r}$ & $\begin{array}{l}\text { div } \\
\text { liv } \\
\text { kid } \\
\text { col }\end{array}$ & $\begin{array}{l}\text { disulfiram } \\
\text { aminoacetonitrile } \\
\text { aminoacetonitrile } \\
\text { aminoacetonitrile }\end{array}$ & $\begin{array}{l}\text { lower } \\
? \\
? \\
?\end{array}$ & $\begin{array}{l}\text { lower } \\
\text { lower } \\
\text { lower } \\
\text { lower }\end{array}$ & $\begin{array}{l}\text { Swenberg [264] } \\
\text { Pegg [205] } \\
\text { Pegg [205] } \\
\text { Pegg [205] }\end{array}$ \\
\hline $\begin{array}{l}\text { 3.3-Dimethyl-1- } \\
\text { phenyltriazene }\end{array}$ & $\mathbf{r}$ & div & protein-free diet & $?$ & \multicolumn{2}{|c|}{$\begin{array}{l}\text { lower in liv, kid } \\
\text { higher in other organs } \\
\text { Kleihues [123] }\end{array}$} \\
\hline Dimethylnitrosamine & $\mathbf{r}$ & liv & $\begin{array}{l}\text { pregnenolone-16 } \alpha \text {-car- } \\
\text { bonitrile } \\
\text { hypophysectomy }\end{array}$ & $\begin{array}{l}\text { ? } \\
\text { lower }\end{array}$ & $\begin{array}{l}\text { equal } \\
\text { equal } \\
\text { lower }\end{array}$ & $\begin{array}{l}\text { Kleihues [121] } \\
\text { Grandjean [80] } \\
\text { Lee }[145]\end{array}$ \\
\hline $\begin{array}{l}\text { Methylnitroso- } \\
\text { urea }\end{array}$ & $\mathbf{r}$ & liv & stress-inducing hormone & $?$ & higher & Magin [162] \\
\hline Aflatoxin $\mathbf{B}_{1}$ & $\mathbf{r}$ & liv & phenobarbital & lower & lower & Garner [72] \\
\hline
\end{tabular}


As was shown in Fig. 1, binding to DNA is a very early event in the chemical induction of a tumor. A large number of factors can influence the steps which lead to DNA binding [74], an equally large number of factors can modulate the response of the animal between DNA binding and the manifestation of a tumor.

The first group of modulatory factors can fully be studied with a binding assay, the second group is beyond the reach of this experimental set-up. In this chapter, those modulatory factors are discussed that have an influence on DNA binding, chapter 6 will show where a DNA-binding assay cannot give an answer to synergisms or antagonisms in chemical carcinogenesis.

Table 27 compiles the relatively few experiments where an influence of a pretreatment of an animal was measured on in vivo DNA binding in the target organ and where the corresponding effect on the tumor incidence is also known. There is a very good correlation between the two end-points, thus again strongly indicating the cause and effect relationship between DNA binding and carcinogenicity.

The carcinogens investigated comprise of aromatic amines and an azo derivative, polycyclic aromatic hydrocarbons, $N$-nitroso compounds, 1,2-dimethylhydrazine, a triazene and aflatoxin $B 1$, i.e. they give a wide selection of the known classes of organic chemical carcinogens.

The pretreatments can be grouped very roughly into the following categories which will also be discussed in this order: enzyme inducing agents (section 5.2), antioxidants (5.3), and effects of special diets, hormones, surgery, as much as they affect DNA binding (section 5.3).

A larger number of reports is available on the effect of a pretreatment of an animal on the binding of a carcinogen to DNA or other macromolecules in an in vitro incubation system. These experiments have much less relevance to the problem of carcinogenicity because of a major lack of inactivating pathways and intracellular compartmentation. The problems associated with such in vitro situations have already been discussed in several places and a number of experiments were cited in section 2.1 where the in vitro binding showed exactly the opposite of the in vivo findings. Due to this lack of correlation, in vitro binding

TABLE 28

EFFECT OF PRETREATMENTS OF ANIMALS ON THE BINDING OF CHEMICALS TO DNA IN IN VITRO INCUBATION SYSTEMS

Selection of references

\begin{tabular}{|c|c|c|c|c|}
\hline Carcinogen & System & Pretreatment & Effect & Reference \\
\hline \multirow[t]{2}{*}{ Benzo $[a]$ pyrene } & rat-liver nuclei & 3-methylcholanthrene & $\begin{array}{l}\text { higher } \\
\text { higher }\end{array}$ & $\begin{array}{l}\text { Jernstroem [113] } \\
\text { Rogan [222] }\end{array}$ \\
\hline & $\begin{array}{l}\text { DNA + mouse- } \\
\text { liver microsomes }\end{array}$ & $\begin{array}{l}\text { butylated hydroxy- } \\
\text { anisole }\end{array}$ & lower & Speier $[253,254]$ \\
\hline $\begin{array}{l}\text { Benzo[a]pyrene and } 7,12- \\
\text { dimethylbenz }[a] \text { anthracene }\end{array}$ & $\begin{array}{l}\text { epidermal } \\
\text { homogenate }\end{array}$ & $\begin{array}{l}\text { butylated hydroxy- } \\
\text { toluene and -anisole }\end{array}$ & lower & Slaga [248] \\
\hline Aflatoxin $B_{1}$ & $\begin{array}{l}\text { DNA of rat-liver } \\
\text { slices }\end{array}$ & phenobarbital & lower & Neal $[186]$ \\
\hline $\begin{array}{l}\text { 3'-Methyl-4-dimethylamino- } \\
\text { azobenzene }\end{array}$ & $\begin{array}{l}\text { DNA + rat-liver } \\
\text { micros. }\end{array}$ & portacaval shunt & lower & Ricco [219] \\
\hline
\end{tabular}


assays were not searched for very thoroughly, and Table 28 gives only a short survey of the chemicals and carcinogens so far involved in this type of study.

\subsection{Enzyme-inducing agents}

The formation of the chemically reactive ultimate carcinogen is dependent upon the activity of the enzymes involved in this process. Induction of these activities is a widely used tool for the modification of the response to a carcinogenic stimulus. The best known inducing agents are phenobarbital (PB) and 3-methylcholanthrene (3MC) and they have also been used in many experiments compiled for Table 27.

It is known that pretreatment with phenobarbital decreases the incidence of tumors from 2-acetylaminofluorene (AAF) and a similar decrease was found for the binding to rat-liver DNA. Pretreatment with 3-methylcholanthrene also inhibits liver carcinogenesis by AAF but not by $N$-hydroxy-AAF, and, indeed, a reduction was found for DNA-bound AAF but not for DNA-bound $N$-hydroxy-AAF.

Hepatocarcinogenicity by aflatoxin $B_{1}\left(A_{F B}\right)$ is reduced by phenobarbital pretreatment and so is the binding of $\mathrm{AFB}_{1}$ to liver DNA. In contrast to this correlation in vivo, there is an increased formation in vitro of the ultimate carcinogen aflatoxin $B_{1}-2,3-o x i d e$ if liver microsomes from phenobarbital-pretreated rats are incubated with $A F B_{1}$ as compared with those from untreated rats.

Similar studies have been performed with azo dyes. The inhibitory effect of phenobarbital on carcinogenesis by azo dyes could be shown to correlate with DNA binding of 4-dimethylaminoazobenzene (still Table 27 for refs.). A similar influence of pretreatment with 3-methylcholanthrene on carcinogenesis and DNA binding seemed to depend strongly on the route of administration and the duration of the pretreatment, and only inconclusive correlations have so far been established.

In the case of these aromatic amines and aflatoxin $B_{1}$ it is therefore the rule that pretreatment with an enzyme inducer decreases tumor incidence and DNA binding. With polycyclic aromatic hydrocarbons, however, the situation seems more complicated and either increasing or decreasing effects were observed (Table 27). This is probably due to the fact that most polycyclic hydrocarbons undergo a multiple-step activation whereas the former examples need only one enzymatic step to form the ultimate carcinogen.

An additional complication arises in that these activating enzyme systems are located not only in the endoplasmic reticulum (microsomes) but also in the nuclear envelope. This latter activity - although much lower - might play an important role for DNA binding because of its closeness to this target.

In this laboratory, we have studied the influence of several enzyme inducers like phenobarbital, 3-methylcholanthrene and dieldrin on aryl hydrocarbon hydroxylase activity $(\mathrm{AHH})$ in rat-liver microsomes and nuclei, and their effect on liver-DNA binding of benzo[a]pyrene (BP). It was found that an induction of microsomal $\mathrm{AHH}$ activity gives rise to increased binding whereas induction of nuclear $\mathrm{AHH}$ went parallel with a decrease of DNA-bound BP [277]. If the relative induction is equal in both cellular compartments, the increasing influence of the microsomes outvalues the decreasing effect by the nuclei. 
These results were in contrast to our working hypothesis, i.e., that an induction of the nuclear $\mathrm{AHH}$ should have an increasing effect on the binding to the nearby DNA. Additional work will be necessary to spot the other critical parameters - enzymatic or not - that modulate the metabolic pathways of BP that generate the ultimate carcinogen(s).

\subsection{Antioxidants, special diets, hormones, surgery}

Antioxidants are widely used food additives and are therefore of special interest in their modifying effect on chemical carcinogenesis. To this group belong butylated hydroxytoluene (BHT), butylated hydroxyanisole (BHA), some benzoflavones, vitamin $\mathrm{C}$, disulfiram, and also the related chemicals vitamin A and other retinoids. In most cases, their influence on carcinogenicity is inhibitory. Caution must however be exerted not to become too optimistic about antioxidants in the diet because there is an example where the carcinogenic activity of dimethylnitrosamine or diethylnitrosamine was shifted from the liver to other organs under the combined treatment with disulfiram [233]. This antioxidant has probably led to a prolonged presence of unmetabolized nitrosamine in the blood so that organs other than the liver increased their activity with respect to the oxidation of the carcinogen. In another report on 2 -acetylaminofluorene (AFF)-induced hepatic tumorigenesis in the rat it was shown that butylated hydroxytoluene, fed after the carcinogen, enhanced the incidence of liver tumors by a factor of about 4 [206].

A small number of reports are available on the effect of antioxidants on DNA binding in vivo (see Table 27 for refs.) and a reduction was indeed found in all cases examined.

BHT decreases. AAF-induced hepatocarcinogenesis and it was also shown to reduce the binding of the carcinogen to rat-liver DNA. Benzo $[a]$ pyrene is carcinogenic to the mouse forestomach after oral intubation. No tumors occur if $1 \%$ disulfiram is added to the diet. This inhibition is paralleled by a 2-fold reduction of $\mathrm{BP}$ binding to DNA and a 6 -fold reduction to RNA of the forestomach. Dietary pretreatment of rats with disulfiram also prevents 1,2-dimethylhydrazine-induced colon carcinogenesis and was found to reduce DNA alkylation to less than $1 \%$ of that detected in animals treated with 1,2-dimethylhydrazine alone. 7,8-Benzoflavone (7,8-BF) and 5,6-BF are synthetic isomers related to naturally occurring flavonoids, some of which have antioxidative properties. 5,6-BF is also an inducer of mouse-skin aryl-hydrocarbon hydroxylase activity whereas the 7,8-isomer inhibits this activity. Administration of these two compounds in general lowered skin-tumor formation and DNA binding from 7,12-dimethylbenz $[a]$ anthracene or dibenz $[a, h]$ anthracene, except that 7,8-BF increased the skin tumor incidence from benzo[ $a]$ pyrene. It therefore seems difficult to discuss a simple mode of action because both compounds interfere with the carcinogenicity on a number of different levels, antioxidation, enzyme induction, and possibly others. Such a multiplicity of effects is also expected from the high riboflavin diet which lowered hepatocarcinogenicity and DNA binding from 4-dimethylaminoazobenzene (Table 27).

What the experiments cited so far have in common is that the amount of reactive metabolite of a carcinogen is affected by the pretreatment, either by changing the activity of metabolizing enzymes or by trapping the ultimate car- 
cinogen with antioxidants. To this same group of experiments belong pretreatments with special diets, e.g., grain diets. In such studies, the activity of detoxifying enzymes, such as glutathione $-S$-transferase is reduced because of a glutathione deficiency. It is therefore not surprising that the concentration of reactive metabolites near the DNA is increased, and that higher DNA binding occurs (2-acetylaminofluorene, Table 27). The effect of a protein-free diet on guanine-7-methylation by 3,3-dimethyl-1-phenyltriazene (Table 27) seems to be more complicated because a marked difference between the liver or kidney and the other organs was found.

Table 27 also lists 3 reports on the effect of a pretreatment with hormones or steroid analogues on DNA binding. With methylnitrosourea it was found that pretreatments of rats with stress-inducing hormones like adrenaline and hydrocortisone enhanced the methylation of liver DNA and RNA. Pregnenolone-16 $\alpha$-carbonitrile (PCN), a hormonally inactive steroid inhibits the acute toxicity of dimethylnitrosamine yet does not affect its overall metabolism in vivo. Methylation of liver DNA by dimethylnitrosamine is also unaffected by such a pretreatment. The same was found in another laboratory and it was concluded that PCN can provide protection against the hepatotoxic effects of DMNA without reduction of the level of alkylation.

Surgery has also been studied for its effect on carcinogenicity. Such experiments belong, in principle, to the next chapter because they affect primarily the cell-division rate as a modulator of carcinogenesis which cannot be studied on the basis of DNA binding. One experiment has been reported, however, where it was shown that a portacaval shunt lowered the incidence of liver tumors in rats treated with $3^{\prime}$-methyl-4-dimethylaminoazobenzene. A parallel reduction of DNA-bound carcinogen led to the assumption that the contribution of the liver to the metabolism of the carcinogen was lowered due to the shunt so that extrahepatic organs increased their share in the drug metabolism.

In short, there is an excellent correlation between DNA binding in vivo and tumor incidence after a number of pretreatments and it is obvious that the measurement of DNA binding is a potent tool in the study of the mechanisms which govern the activation-inactivation processes with organic carcinogens.

\subsection{Effect of dose and dose schedule on the CBI}

\subsubsection{Dose-binding relationships}

With radiolabelled compounds of high specific activity it is possible to measure a DNA binding from a dose which is orders of magnitude below those normally used in long-term bioassays on carcinogenicity. In the latter experiments, the limited number of animals requires an unnaturally high dosage for the induction of a statistically significant number of tumors. The highest dose is often chosen at the limit tolerated by the animals so that non-toxic compounds like saccharin can be tested at unrealistically high levels where, eventually, secondary effects might lead to tumors.

For the calculation of a CBI the DNA binding is divided by the dose administered with the implicit assumption that there is a linear dose-binding relationship. For the reasons outlined in section 2.3.2 this does not have to be the case and the CBI obtained from a high dose necessary for a suitable limit of detec- 
tion of a binding might not be the same as the one from a much lower, environmental exposure.

Dose-binding relationships have therefore been performed with a number of carcinogens listed in Tables 13-20.

With benzo[ $a]$ pyrene (Table 14) a non-linear relationship was found in a dose range of $40 \mu \mathrm{g} / \mathrm{kg}$ to $4 \mathrm{mg} / \mathrm{kg}$, with a sigmoid step between 1 and $2 \mathrm{mg} /$ $\mathrm{kg}$. The non-linearity was attributed to an induction of the activating enzymes which, indeed, starts from a single intraperitoneal dose of $2 \mathrm{mg} / \mathrm{kg}$ [159]. 7,12. Dimethylbenz $[a]$ anthracene (Table 14) gave the same CBI for liver DNA from doses of $120 \mu \mathrm{g} / \mathrm{kg}$ or $25 \mathrm{mg} / \mathrm{kg}$, but the dose-binding relationship between these two points is not known. o-Aminoazotoluene (Table 16) gave rise to a linear dose-binding response from 12 to $108 \mu \mathrm{g}$ per mouse. The binding of trans-dimethylaminostilbene (Table 17) to rat-liver DNA also increased linearly with doses ranging from 0.025 to $2.5 \mu \mathrm{mol} / \mathrm{kg}$, plateauing-off beyond that dose. The CBI of 1,2-dimethylhydrazine (Table 17) decreases about 4-fold after an increase of the dose by a factor of 50. Dimethylnitrosamine (Table 18) showed a linear dose-binding relationship from doses of $1-27 \mathrm{mg} / \mathrm{kg}$, and also urethane (Table 20) had a constant CBI for mouse-liver DNA within a 10-fold dose range.

This evidence of linear dose-binding relationships with compounds of many different chemical classes makes it clear that a measurement of a dose-binding relationship will not, a priori, be required for short-term testing of chemicals with a DNA-binding assay in vivo. The rare non-linearities cited are small, as compared with the order of magnitude which determines the carcinogenic potency of a chemical. If, however, an extrapolation of high-dose data from a long-term bioassay to lower dosage is attempted, a dose-dependent DNA-binding assay might well be the method of choice.

\subsubsection{Dose-schedule}

Most experiments where a CBI has been determined are on the basis of a single administration as discussed in section 2.3.2. Pretreatments of the animals with the carcinogen, i.e. a simulation of chronic exposure, has been performed on rare occasions with very interesting results.

With dimethylnitrosamine (Table 18), a pretreatment did not clearly change the total amount of DNA binding in liver or kidney but it resulted in a drastic build-up of $O(6)$-methylguanine in kidney, the target organ from that schedule. This experiment therefore revealed the overload of the DNA-repair activity in kidney after repetitive exposure. This important result would not have been found from a single administration.

Prefeeding of mice with $o$-aminoazotoluene (Table 16) gave rise to a 4 -fold decrease in the CBI for liver DNA but not for protein. The reason for this is not entirely clear, nor is its effect on the tumor formation.

These two examples show that prefeeding might be a valuable tool for the elucidation of biological responses to repetitive or chronic exposure to carcinogens.

\subsubsection{More than one carcinogen at a time}

We are not aware of any report on the in vivo alkylation of DNA from the 
simultaneous administration of two or more radiolabelled carcinogens although this approach might be very valuable for the understanding of synergisms and antagonisms in chemical carcinogenesis. We are in our environment constantly exposed to a number of carcinogens and it is surprising how rare reports on the cumulative effect of carcinogens are. One main reason for this lack of information is that the work involved in long-term tests is already big enough with the single chemicals so that it is impossible to study the multiple combinations of carcinogens with such bioassays. The study of DNA binding and repair could well be a valuable approach to this type of problem.

Nice experiments have been reported where rats were pretreated with a number of carcinogens. Their effect on the methylation of guanine at position 7 and $O(6)$ by methylnitrosourea was then studied. It could be demonstrated that the excision-repair system for $O(6)$-methylguanine in rat liver can be overloaded and requires several days to recover and restore its initial capacity [122].

6. Modulatory factors in chemical carcinogenesis which cannot or not completely be studied on the basis of DNA binding

\subsection{Modulations of the events between DNA binding and tumor}

Between the covalent binding of a carcinogen to DNA and the manifestation of a tumor there are many steps which contribute to the final response of the animal to the carcinogenic stimulus. A number of these steps, like DNA repair or the mutagenicity of a specific DNA adduct, can in principle be studied with binding experiments (sections 4.3 and 4.4), but there is thereafter a sequence of biological events which cannot be studied on the basis of DNA binding. How these steps are modulated and what the consequences are for the process of tumor formation is outlined in the next sections.

\subsubsection{Mitotic activity}

A DNA damage can only then be responsible for a heritable change when a DNA replication leads to a mutation before the damage is repaired. Mitotic activity is therefore of prime importance and all secondary influences which accelerate cell division are likely to increase the susceptibility to a carcinogenic stimulus. This has clearly been shown with partial hepatectomy (referred to as "ph" in the Tables) where the liver, in its regenerating phase, is much more prone to develop cancer $[49,50]$, even from carcinogens that do not normally attack the liver. Small bowel resection also enhances carcinogenicity by 1,2 dimethylhydrazine and azoxymethanol [197]. Similar but not so drastic effects can be obtained after necrotic alterations of the liver, e.g., with carbon tetrachloride [144], or with drugs that stimulate cell division like phenobarbital and other synthetic or naturally occurring substances.

Phenobarbital has already been discussed as an enzyme inducer but it is also a mitotic stimulant. It can therefore affect carcinogenicity on various levels and we have the complicated situation that a pre-treatment of rats with phenobarbital reduces hepatocarcinogenesis of 2-acetylaminofluorene by changing the metabolic pathways, whereas it increases the tumor incidence if it is given after the carcinogen and acts as a cocarcinogen probably on cell division. 
Mitotic activity is governed primarily by the organ itself, by the function and life-time of its cells. At a first glance, one would think that rapidly dividing cell populations like bone-marrow stem cells, intestinal epithelia, skin and germ-line cells would be most susceptible to chemical carcinogenesis [reviews on these problems: 27,28 ]. This is only partly true because these organs are very limited with respect to drug activation and metabolism, and some have very active DNA repair.

\subsubsection{Promoters and hormones}

A related group of compounds, termed "promoters", do not cause cancer by themselves. They were first discovered for their ability to promote the growth of skin tumors in mice which had been treated with doses of carcinogens too low to induce tumors on their own. These phorbol derivatives were for a long time regarded as mitotic stimulants (see above) but recent experiments show that promoters might affect the differentiation of cells and it has been suggested that this type of substance may keep mutant cells alive, prevent them from differentiation (which would ultimately lead to cell death) until enough mutations have occurred that they can survive to form tumors.

Hormones form a group of chemical carcinogens and teratogens with a controversial mode of action. We have been able to show a weak covalent binding activity of estrone, ethinylestradiol and diethylstilbestrol to liver DNA in vivo (Table 20). Their carcinogenicity could therefore well be based upon their chemical reactivity. On the other hand, most of the tumors associated with hormones are tumors of the target organs of their hormonal activity so that their carcinogenicity might also be due to mitotic stimulation or promoting activity. There is as yet no conclusive evidence for the more important mode of action.

\subsubsection{Probability of transformation. Immunology}

Another critical point in the development of a chemically induced tumor is the probability that a mutation or a number of mutations leads to cell death or to what is termed "transformation", i.e., loss of growth control and invasive growth characteristics. Although we do not know of any experimental data it is conceivable that different organs and different stages of cell differentiation might also have an influence on the ease with which a transformation can occur. It is clear that such aspects will never be elucidated with DNA binding as an indicator in the process of chemical carcinogenesis.

A critical review is available on the influence of the immune system in cancer research [259]. It would not be wise to discuss these very complicated interactions in this review. Suffice it to say that immunological influences must also play a role in cancer formation and treatment and that these modulatory factors are far beyond the reach of a DNA-binding experiment.

\subsection{Whole-system responses}

\subsubsection{Susceptibility of various species}

It is well known that the carcinogenic activity of many compounds is species-specific, and there is a number of experiments available where DNA bind- 
ing has been determined in susceptible and non-susceptible species. In most cases, there is a qualitative correlation between DNA binding and susceptibility. On a quantitative basis, however, the observed differences in DNA binding are often too small to account for the total difference. It must therefore be concluded that the species differences are based partly on differences in the steps leading to DNA binding and partly on differences in the events between DNA binding and tumor formation. The following examples might illustrate this situation.

Carbon tetrachloride (Table 13) is hepatocarcinogenic for mice but much less so for rats, and liver-DNA binding was indeed detected only in the mouse. Benzo[a]pyrene (Table 14) is more effective on the skin of mice than of rats, and the binding to DNA of mouse organs is generally higher than in the rat, possibly because of the higher activity of epoxide hydratase in the latter species. Aflatoxin B1 (Table 19) is strongly hepatocarcinogenic for the rat, much less so for the hamster or the mouse. The same difference is found with DNA binding. Diethylstilbestrol increases the incidence of tumors in organs which are targets for its activity as a hormone. The male hamster develops, in addition, kidney tumors. This special susceptibility of the hamster was also seen with respect to DNA binding (Table 20 ).

No such correlation was found in the following examples: 4-dimethylaminoazobenzene (Table 16) is hepatocarcinogenic for the rat but not for the guinea pig. The binding to DNA is about the same. Treatment of rats, mice and guinea pigs with ethionine (Table 25) yielded 7-methylguanine from liver DNA in all species although only the rat is susceptible to the hepatocarcinogenic activity of this compound.

\subsubsection{Different susceptibility of strains}

The differences in the susceptibility of various strains to a carcinogen can be quite as striking as between different species. The following examples show that this variability cannot be assessed with the measurement of DNA binding as well as was possible with different species. It seems more likely that the strain differences are due to the steps between DNA binding and tumor formation.

The covalent binding of 3 polycyclic hydrocarbons to DNA was studied in the skin of mice of different strains. The level of binding did not show a correlation with the reported susceptibilities of the 3 strains [207]. Methylation of lung and liver DNA was studied in two inbred strains of mice with widely different susceptibility to tumor formation by dimethylnitrosamine (Table 18). No strain differences could be demonstrated in the total amount and time course of DNA methylation. It has been discussed before that total methylation might not be the correct means of assessing DNA damage because of the widely varying consequences of the different sites of alkylation. In favour of the above experiment it can however be said that the pattern of DNA binding should be the same in both strains. Furthermore, a similar experiment was performed where $O(6)$-methylation was measured from methylnitrosourea (Table 24 ) in two mouse strains with different susceptibility to the formation of brain tumors. It was found that total DNA binding, $O(6)$-methylation of guanine and $O(6)$-methylguanine repair were very similar in the brain of both strains. In the 
liver, which is an equally good target for both strains, there was a distinct difference in total methylation and the rate of $O(6)$-methylguanine removal.

Positive correlations between DNA binding and differences in susceptibility of different strains are also available, e.g. for the binding of $\beta$-propiolactone (Table 21) to skin DNA of 2 strains of mice, for 2-naphthylamine (Table 23) where the binding to liver DNA of 2 strains of mice correlated with the corresponding susceptibility to hepatic tumor formation. With 1,2-dimethylhydrazine, the low carcinogenic response of C57BL/Ha mice seems due to the smaller extent of initial methylation of colon DNA as compared to a more susceptible strain [40]. With trichloroethylene, in vitro binding to microsomal protein (DNA was not examined) correlated with the susceptibility of these strains of mice [4].

\subsubsection{Differences from sex and age}

Differences are also found with respect to the sex of the animals. We are aware of one example where this is reflected by the in vivo DNA binding. 1'-Hydroxysafrole (Table 19) is moderately hepatocarcinogenic for female mice but only weakly for males. This difference is evident from liver-DNA binding with CBI of 280 for females and $\mathbf{5 . 5}$ for males.

Cases are known where the susceptibility to a carcinogenic stimulus is dependent on the age of the animal. 7,12-Dimethylbenz[a]anthracene (Table 14) induces mammary tumors most readily if the female rats are about 50 days old. Binding of the carcinogen to DNA of the mammary gland was highest in animals of this age as compared with 35- or 120-day old ones and it persisted for a longer time.

The examples discussed in this section show that DNA binding is a necessary but not sufficient event in the induction of a tumor by a genotoxic organic chemical. The differences in the susceptibility with respect to species, strain, sex and age can therefore only partly be based on differences in the binding to DNA of the target organ. Species differences are relatively well followed with DNA binding whereas the experimental evidence with various strains indicates that the reasons for a different susceptibility rather lies between DNA binding and tumor formation.

\section{Conclusions}

The most probable mechanism of tumor initiation by genotoxic carcinogens involves the covalent binding of the compound or one of its metabolites to DNA of the target organ.

This DNA binding can be measured in intact mammalian organisms with the use of radioactive chemicals in a low dose range which would be ineffective in the standard long-term bioassay on carcinogenicity. Dose-response relationships for DNA binding in vivo provide a useful approach for the extrapolation from the high dosage of long-term bioassays to lower doses.

The determination of "Covalent Binding Indices", CBI, might be a valuable tool in the quantification of the potency of a genotoxic chemical carcinogen. This was shown by the correlation of hepatocarcinogenic potency with CBI for liver DNA. Short-term tests based on mutagenicity data do not yield a similar 
quantitative correlation with carcinogenicity. A number of compounds, such as nitrosamines, 1,2-dimethylhydrazine, methylazoxymethanol, carbon tetrachloride, or urethane, are by orders of magnitude less mutagenic in the Ames test than "expected" from carcinogenicity data.

The quantitative correlation of DNA binding with carcinogenic potency can be improved if two important aspects are included in the evaluation: (i) the persistence of DNA-bound chemical and (ii) the probability for a mutation to occur.

(i) A carcinogen-induced DNA-DNA mispairing can only occur if the damage is not repaired before the DNA is replicating. DNA-repair capabilities and mitotic activity are therefore important organ-specific parameters which can be evaluated in part in separate experiments, e.g., with a time-dependence of DNA binding.

(ii) The probability for a mutation to occur when damaged DNA is replicating depends both upon the exact site of DNA binding as well as on the structure of the chemical bound. This probability can be estimated from an experiment where mutagenic events are scored simultaneously with a determination of the binding of the carcinogen to the DNA of the mutagenicity test system.

The most reliable quantification of a carcinogenic potency on the basis of DNA binding is obtained when structurally related compounds are compared with each other. It can, in such a case, be assumed that persistence on the DNA and mutagenicity of the DNA adduct do not differ much.

A number of pretreatments of animals have been shown to change the incidence of tumors from a chemical carcinogen. This is in most cases due to changes in the activating/inactivating pathways for the carcinogen. Generally, DNA binding in vivo paralleled the observed effect on tumor formation. DNA binding can therefore be a fast and useful indicator in the study of influences of various types of pretreatments on the tumor incidence.

Limitations for a DNA-binding assay:

Radioactively labelled chemical must be available for a DNA-binding assay in vivo.

Organotropy of chemical carcinogens cannot be based quantitatively upon the measurement of DNA binding alone.

Differences in the susceptibility of species, strains, sex or age towards chemical carcinogens can only partly be explained on the basis of DNA binding.

Factors which affect the biological sequence of events between DNA binding and tumor formation cannot be assessed with a binding assay. These include mitotic stimulants, promoters, hormones, immunological changes.

\section{References}

1 Aaron, C.S., and W.R. Lee, Molecular dosimetry of the mutagen ethylmethanesulfonate in Drosophila melanogaster spermatozoa: linear relation of DNA alkylation per spem cell (dose) to sex-linked recessive lethals, Mutation Res., 49 (1978) 27-44.

2 Ames, B.N., J. McCann and E. Yamasaki, Methods for detecting carcinogens and mutagens with the Salmonella/mammalian microsome mutagenicity test, Mutation Res., 31 (1975) 347-364.

3 Ashby, J., and J.A. Styles, Does carcinogenic potency correlate with mutagenic potency in the Ames assay?, Nature (London), 271 (1978) 452-455. 
4 Banerjee, S., and B.L. van Duuren, Covalent binding of the carcinogen trichloroethylene to hepatic microsomal proteins and to exogenous DNA in vitro, Cancer Res., 38 (1978) 776-780.

5 Bartsch, H., G.P. Margison, C. Malaveille, A.M. Camus, G. Brun and J.M. Margison, Some aspects of metabolic activation of chemical carcinogens in relation to their organ specificity, Arch. Toxicol.. 39 (1977) $51-63$.

6 Bhide, S.V., E. Premkumar, M.A. Siddiqui and P.M. Bhargava, Some preliminary observations on the binding of urethan to DNA of several tissues of mice and rats, Indian J. Cancer, 8 (1971) 172-175.

7 Bhide, S.V., Urethane interaction with nucleic acids and proteins from non-malignant fast growing tissues, Chem.-Biol. Interact., 8 (1974) 19--23.

8 Bolt, H.M., H. Kappus, A. Buchter and W. Bolt, Disposition of [1,2-carbon 14$]$ vinyl chloride in the rat, Arch. Toxicol., 35 (1976) 153-162.

9 Bolt, H.M., and H. Remmer, Implication of rifampicin-quinone in the irreversible binding of rifampicin to macromolecules, Xenobiotica, 6 (1976) $21-32$.

10 Bolt, H.M., H. Kappus, R. Kaufmann, K.E. Appel, A. Buchter and W. Bolt, Metabolism of carbon-14 vinyl chloride in vitro and in vivo, INSERM Symposia Ser., 52 (1976) 151-164.

11 Bonanomi, L., D. Della Bella and A. Gazzaniga, Newer developments in chloramphenicol metabolism, Pharmacol. Res. Commun., 7 (1975) 437-441.

1.2 Borchert, P., and L.W. Wattenberg, Inhibition of macromolecular binding of benzo[a]pyrene and inhibition of neoplasia by disulfiram in the mouse forestomach, J. Natl. Cancer Inst., 57 (1976) 173179.

13 Bowden, G.T., B.G. Shapes and R.K. Boutwell, The binding of 7,12-dimethylbenz [a]anthracene to replicating and non-replicating DNA in mouse skin, Chem.-Biol. Interact., 8 (1974) 379-394.

14 Bowden, G.T., and R.K. Boutwell, The replication of mouse skin epidermal DNA to which is bound 7,12-dimethylbenz [a] anthracene, Chem.-Biol. Interact., 9 (1974) 15-23.

15 Bowden, G.T., T.J. Slaga, B.G. Shapes and R.K. Boutwell, The role of aryl hydrocarbon hydroxylase in skin tumor initiation by 7,12-dimethylbenz [a] anthracene and 1,2,5,6-dibenzanthracene using DNA binding and thymidine-H-3 incorporation into DNA as criteria, Cancer Res., 34 (1974) 2634-2642.

16 Boyd, M.R., and R.A. Neal, Studies on the mechanism of toxicity and of development of tolerance to the pulmonary toxin, $\alpha$-naph thylthiourea (ANTU), Drug Metabol. Dispos., 4 (1976) 314-322.

17 Boyd, M.R., C.N. Statham, R.B. Franklin and J.R. Mitchell, Pulmonary bronchiolar alkylation and necrosis by 3-methylfuran, a naturally occurring, potential atmospheric contaminant, Nature (London), 272 (1978) 270-271.

18 Boyland, E., and K. Williams, Reaction of urethane with nucleic acids in vivo, Biochem. J. 111 (1969) $121-127$.

19 Bridges, B.A., Short term screening tests for carcinogens, Nature (London), 261 (1976) 195-200.

20 Brookes, P., and P.D. Lawley, The reaction of mustard gas with nucleic acids in vitro and in vivo, Biochem. J., 77 (1960) $478-484$.

21 Brookes, P., and P.D. Lawley, Evidence for the binding of poly nuclear aromatic hydrocarbons to the nucleic acids of mouse skin: relation between carcinogenic power of hydrocarbons and their binding to deoxyribonucleic acid, Nature (London), 202 (1964) 781-784.

22 Brookes, P., and P.D. Lawley, Reaction of some mutagenic and carcinogenic compounds with nucleic acids, J. Cell. Comp. Physiol., 64, Suppl. 1 (1964) 111-128.

23 Brookes, P., and P.D. Lawley, In vivo reactions of isotopically labeled alkylating agents, in: L.J. Roth (Ed.), Isotopes in Experimental Pharmacology, The University of Chicago Press. Chicago, 1965, pp. 403-414.

24 Brookes, P., Quantitative aspects of the reaction of some carcinogens with nucleic acids and the possible significance of such reactions in the process of carcinogenesis, Cancer Res., 26 Part 1 (1966) 1994-2003.

25 Brookes, P., Role of covalent binding in carcinogenicity, in: D.J. Jollow et al. (Eds.), Biological Reactive Intermediates, Plenum, New York, 1977, pp. 470-480.

26 Buechcler, J., and P. Kleihues, Excision of $O(6)$-methylguanine from DNA of various mouse tissues following a single injection of $N$-methyl- $N$-nitrosourea, Chem.-Biol. Interact., 16 (1977) 325-333.

27 Cairns, J., Mutation selection and the natural history of cancer, Nature (London), 255 (1975) 197200.

28 Cairns, J., The cancer problem, Sci. Am., 233 (1975) 64-78.

29 Carlassare, F.. C. Antonello, F. Baccichetti and P. Malfer, On the binding of benz[a]pyrene to DNA "in vivo", Z. Naturforsch., 27b (1972) 200-202.

30 Chargaff, E., (Ed.), The Nucleic Acids, Academic Press, New York, 1955.

31 Chauveau, J., M. Meunier and A. Benoit, Binding of metabolites of dietary 4-dimethylaminoazobenzene and 2-methyl-4-dimethylaminoazobenzene to rat liver DNA and protein of subcellular fractions, Int. J. Cancer, $13(1974) 1-8$.

32 Chen, $C_{\text {., }}$ and $S$. Lee, Covalent binding of norethynodrel to proteins and glutathione initiated by rat liver oxygenase, Mol. Pharmacol., 11 (1975) 409-420.

33 Chun, E.H.L., L. Gonzales, F.S. Lewis, J. Jones and R.J. Rutman, Differences in the in vivo alkylation and cross-linking of nitrogen mustard-sensitive and -resistant lines of Lettre-Ehrlich ascites tumors, Cancer Res., 29 (1969) $1184-1194$. 
34 Cleaver, J.E., Methods for studying repair of DNA damaged by physical and chemical carcinogens, in: H. Busch (Ed.), Methods of Cancer Research, Vol. 11, Academic Press, New York, 1975, pp. 123165.

35 Colburn, N.H., and R.K. Boutwell, The binding of $\beta$-propiolactone to mouse skin DNA in vivo; its correlation with tumor-initiating activity, Cancer Res., 26 Part 1 (1966) 1701-1706.

36 Colburn, N.H., and R.K. Boutwell, The in vivo binding of $\beta$-propiolactone to mouse skin DNA, RNA and protein, Cancer Res., 28 (1968) 642-652.

37 Colburn, N.H., and R.K. Boutwell, The binding of $\beta$-propiolactone and some related alkylating agents to DNA, RNA, and protein of mouse skin; relation between tumor-initiating power of alkylating agents and their binding to DNA, Cancer Res., 28 (1968) 653-660.

38 Connors, T.A., A. Jeney, G.P. Warwick and M.E. Whisson, Some factors influencing the sensitivity of tumors to nitrogen mustards, in: L.J. Roth (Ed.), Isotopes in Experimental Pharmacology, The University of Chicago Press, Chicago, 1965, pp. 433-438.

39 Coombs, M.M., T.S. Bhatt and C.W. Vose, The relationship between metabolism, DNA binding, and carcinogenicity of 15,16-dihydro-11-methylcyclopenta[ $a$ ]phenanthren-17-one in the presence of a microsomal enzyme inhibitor, Cancer Res., 35 (1975) 305-309.

40 Cooper, H.K., J. Buecheler and P. Kleihues, DNA alkylation in mice with genetically different susceptibility to 1,2-dimethylhydrazine-induced colon carcinogenesis, Cancer Res., 38 (1978) 3063-3065.

41 Cox, R., and E. Farber, Ethylation of DNA versus cancer induction with ethlonine, Proc. Am. Ass. Cancer Res., 13 (1972) 97.

42 Craddock, V.M., and P.N. Magee, Methylation of liver DNA in the intact animal by the carcinogen dime thy lnitrosamine during carcinogenesis, Biochim. Biophys. Acta, 95 (1965) 677-678.

43 Craddock, V.M., and P.N. Magee, Analy sis of bases of rat-liver nucleic acids after administration of the carcinogen dimeth ylnitrosamine, Biochem. J., 100 (1966) 724-732.

44 Craddock, V.M., and P.N. Magee, Effect of administration of the carcinogen dimethylnitrosamine on urinary 7-methylguanine, Biochem. J., 104 (1967) 435-440.

45 Craddock, V.M., Stability of deoxyribonucleic acid methylated in the intact animal by administration of dimethylnitrosamine, Biochem. J., 111 (1969) 497-502.

46 Craddock, V.M. The reaction of $N$-methyl- $N^{\prime}$-nitro- $N$-nitrosoguanidine with $D N A$ in the intact animal, Chem.-Biol. Interact., 1 (1969/70) 234-237.

47 Craddock, V.M., Analysis of DNA for the formation of 3-methylthymine after administration of dimethylnitrosamine, Chem.-Biol. Interact., 4 (1971/72) 149-154.

48 Craddock, V.M., The pattern of methylated purines formed in DNA of intact and regenerating liver of rats treated with the carcinogen dimethylnitrosamine, Biochim. Biophys. Acta, 312 (1973) 202-210.

49 Craddock, V.M., Effect of a single treatment with the alkylating carcinogens dimethylnitrosamine, diethylnitrosamine and methyl methanesulphonate, on liver regenerating after partial hepatectomy, I. Test for induction of liver carcinomas, Chem.-Biol. Interact., 10 (1975) 313-321.

50 Craddock, V.M., Ef fect of a single treatment with the alkylating carcinogens dimethylnitrosamine, diethylnitrosamine and methyl methanesulphonate, on liver regenerating after partial hepatectomy, II. Alkylation of DNA and inhibition of DNA replication, Chem.-Biol. Interact., 10 (i975) 323-332.

51 Croy, R.G., J.M. Essigmann, V.N. Reinhold and G.N. Wogan, Identification of the principal aflatoxin B1-DNA adduct formed in vivo in rat liver, Proc. Natl. Acad. Sci. (U.S.A.), 75 (1978) 1745-1749.

52 Decloitre, F., M. Martin and J. Chauveau, Comparative effect of phenobarbital and 3-methylcholanthrene on azodye metabolism in rat liver, I. In vitro studies on detoxication and activation processes, Chem.-Biol. Interact., 10 (1975) 229-238.

53 Decloitre, F., M. Martin and J. Chauveau, Comparative effect of phenobarbital and 3-methylcholanthrene on azodye metabolism in rat liver. II. In vivo binding of metabolites to cellular macromolecules, Chem.-Biol. Interact., 10 (1975) 301-307.

54 Deutsch, M.J., D.L. Roerig and R.I.H. Wang, Peroxidase-catalyzed irreversible binding of morphine to protein, Biochem. Pharmacol., 26 (1977) $1267-1269$.

55 Dingman, C.W., and M.B. Sporn, The binding of metabolites of aminoazo dyes to rat liver DNA in vivo, Cancer Res., 27, Part 1 (1967) 938-944.

56 Docks, E.L., and G. Krishna, Covalent binding of trans-stilbene to rat liver microsomes, Biochem. Pharmacol., 24 (1975) 1965-1969.

57 Doerjer, G., H. Diessner, J. Buecheler and P. Kleihues, Reaction of 7,12-dimethylbenz [a]anthracene with DNA of fetal and maternal rat tissues in vivo, Int. J. Cancer, 22 (1978) 288-291.

58 Duncan, M., P. Brookes and A. Dipple, Metabolism and binding to cellular macromolecules of a series of hydrocarbons by mouse embry o cells in culture, Int. J. Cancer, 4 (1969) 813-819.

59 Dybing, E., T. Aune and S.D. Nelson, Covalent binding of 2,4-diaminoanisole and 2,4-diaminotoluene in vivo, Arch. Toxicol., Suppl. 1 (1978) 213-217.

60 El-Hawari, A.M., and G.L. Plaa, $\alpha$-Naphthylisothiocyanate (ANIT) hepatotoxicity and irreversible binding to rat liver microsomes, Biochem. Pharmacol., 26 (1977) 1857-1866.

61 Engelse, L. den, P.A.J. Bentvelzen and P. Emmelot, Studies on lung tumors, I. Methylation of deoxyribonucleic acid and tumour formation following administration of dimethylnitrosamine to mice, Chem.-Biol. Interact., 1 (1969/70) 395-406. 
62 Engelse, L. den, and P. Emmelot, Effects of feeding the carcinogen dimethylnitrosamine on its metabolism and methylation of DNA in the mouse, Chem.-Biol. Interact., $4(1971 / 72) 321-327$.

63 Engelse, L. den, and E.J. Philippus, In vivo repair of rat liver DNA damaged by dimethylnitrosamine or diethylnitrosamine, Chem.-Biol. Interact., 19 (1977) 111-124.

64 Falk, H.L., Possible mechanisms of combination effects in chemical carcinogenesis, Oncology, 33 (1976) 77-85.

65 Farber, E., J. McConomy and B. Frumanski, Relative degrees of labeling of liver DNA and RNA with ethionine, Proc. Am. Ass. Cancer Res., 8 (1967) 16.

66 Flora, S. de, Metabolic deactivation of mutagens in the Salmonella-microsome test, Nature (London), 271 (1978) $455-456$.

67 Frei, J.V., Tissue-dependent differences in DNA methylation products of mice treated with methyllabelled methylnitrosourea, Int. J. Cancer, 7 (1971) $436-442$.

68 Frei, J.V., and P.D. Lawley, Methylation of DNA in various organs of C57B1 mice by a carcinogenic dose of $N$-methyl- $N$-nitrosourea and stability of some methylation products up to 18 hours, Chem. Biol. Interact., 10 (1975) 413-427.

69 Frei, J.V., Some mechanisms operative in carcinogenesis. A review, Chem.-Biol. Interact., 13 (1976) $1-25$.

70 Garner, R.C., E.C. Miller, J.A. Miller, J.V. Garner and R.S. Hanson, Formation of a factor lethal for $S$. typhimurium TA 1530 and TA 1531 on incubation of aflatoxin B1 with rat liver microsomes, Biochem. Biophys. Res. Commun., 45 (1971) 774-780.

71 Garner, R.C., and C.M. Wright, Binding of [C-14] aflatoxin B1 to cellular macromolecules in the rat and hamster, Chem.-Biol. Interact., 11 (1975) 123-131.

72 Garner, R.C., Reduction in binding of [C-14] ]aflatoxin B1 to rat liver macromolecules by phenobarbitone pretreatment. Biochem. Pharmacol.. 24 (1975) $1553-1556$.

73 Gerchman, L.L., and D.B. Ludlum, The properties of $O(6)$-methylguanine in templates for RNA polymerase, Biochim. Biophys. Acta, 308 (1973) 310-316.

74 Gillette, J.R., Factors that affect the covalent binding and toxicity of drugs, in: Pharmacology and the Future of Man, Proc. 5th Int. Congr. Pharmacology, San Francisco 1972, Vol. 2, Karger, Basel, 1973, pp. $187-202$.

75 Gillette, J.R., and L.R. Pohl, A prospective on covalent binding and toxicity, J. Toxicol. Envixon, Health, 2 (1977) 849-871.

76 Giri, S.N., D.H. Gribble and S.A. Peoples, Distribution and binding of radioactivity in the starling aftex intravenous administration of [C-14]3-chloro-p-toluidine, Exp. Mol. Pathol., 24 (1976) 392404.

77 Golberg, L., Short term predictive tests, in: W.A.M. Duncan (Ed.), Experimental Model Systems in Toxicology and their Significance in Man, Excerpta Medica, Amsterdam, 1974, pp. 178-191.

78 Goodman, J.I., J.E. Trosko and J.D. Yager Jr., Studies on the mechanism of inhibition of 2-acetylaminofluorene toxicity by butylated hydroxytoluene, Chem.-Biol. Interact., 12 (1976) 171-182.

79 Goshman, L.M., and C. Heidelberger, Binding of tritium-labeled polycyclic hydrocarbons to DNA of mouse skin, Cancer Res., 27 (1967) 1678-1688.

80 Grandjean, C.J., and A. Somogyi, Ef fect of pregnenolone-16 $\alpha$-carbonitrile on the metabolism of dimethylnitrosamine and binding to rat liver macromolecules, Biochem. Pharmacol., 25 (1976) 20972098.

81 Green, T., and D.E. Hathway, The biological fate in rats of vinyl chloride in relation to its oncogenicity, Chem.-Biol. Interact., 11 (1975) 545-562.

82 Green, T., and D.E. Hathway, Interactions of vinyl chloride with rat liver DNA in vivo, Chem.-Biol. Interact., 22 (1978) 211-224.

83 Grilli, S., P. Rocchi and G. Prodi, Nonenzymatic and microsome-dependent binding of polycyclic hydrocarbons to DNA and polynucleotides, Chem.-Biol. Interact., 11 (1975) 351-363.

84 Grilli, S., C. de Giovanni, G. Prodi and A.G. Giumanini, In vivo reaction of dimethylnitrosamine with nucleic acids, Gann, 69 (1978) 39-45.

85 Guengerich, P.F., Studies on the activation of a model furan compound, Toxicity and covalent binding of 2-(Nethylcarbamoylhydroxymethyl)furan, Biochem. Pharmacol., 26 (1977) 1909-1915.

86 Harbers, E., P. Warnecke, H. Hollandt and K. Kruse, Untersuchungen zur Alkylierung von Chromatin in der Rattenleber nach Gabe von [H-3]-Cyclophosphamid - "Feinverteilung" und Kinetik, Z. Krebsforsch., 88 (1977) $237-254$.

87 Hawks, A., P:F. Swann and P.N. Magee, Probable methylation of nucleic acids of mouse colon by 1,2 dimethylh ydrazine in vivo, Biochem. Pharmacol., 21 (1972) 432-433.

88 Hecker, E., Cocarcinogens and cocarcinogenesis, in: E. Grundmann (Ed.), Handbuch der allgemeinen Pathologie, VI/6, Springer, Berlin, 1975, pp. 651-676.

89 Hefner, Jr.. R.E., P.G. Watanabe and P.J. Gehring, Preliminary studies of the fate of inhaled vinyl chloride monomer in rats, Ann. N.Y. Acad. Sci., 246 (1975) 135-148.

90' Heidelberger, C., and G.R. Davenport, Local functional components of carcinogenesis, Acta Unio Int. Contra Cancrum, 17 (1961) 55-63. 
91 Heidelberger, C., Chemical carcinogenesis, Annu. Rev. Biochem., 44 (1975) 79-121.

92 Helmes, C.T., T. Hillesund and R.K. Boutwell, The binding of tritium-labeled phorbol esters to the macromolecular constituents of mouse epidermis, Cancer Res., 34 (1974) 1360-1365.

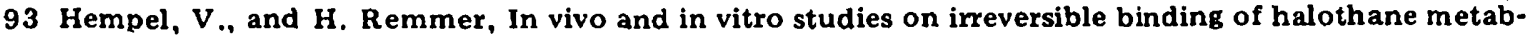
olites to protein, Experientia, 31 (1975) 680-681.

94 Hiatt, H.H. (Ed.), Origins of Human Cancer, Cold Spring Harbor Conferences on Cell Proliferation, Vol. 4, Cold Spring Harbor Laboratory, 1977.

95 Hill, D.L., T.-W. Shih, T.P. Johnston and R.F. Struck, Macromolecular binding and metabolism of the carcinogen 1,2-dibromoethane, Cancer Res., 38 (1978) 2438-2442.

96 Hinson, J.A., S.D. Nelson and J.R. Mitchell, Studies on the microsomal formation of arylating metabolites of acetaminophen and phenacetin, Mol. Pharmacol., 13 (1977) 625-633.

97 Hughes, P.E., and R. Pilczyk, The in vivo binding of metabolites of 2-naphthylamine to mouse-liver DNA, RNA and protein, Chem-Biol. Interact., 1 (1969/70) 307-314.

98 Iball, J., The relative potency of carcinogenic compounds, Am. J. Cancer, 35 (1939) 188-190.

99 Ikegami, S., N. Nemoto, S. Sato and T. Sugimura, Binding of [C-14]-labeled 4-nitroquinoline 1-oxide to DNA in vivo, Chem.-Biol. Interact., $1(1969 / 70) 321-330$.

100 Dett, K.F., W.D. Reid, I.G. Sipes and G. Krishna, Chloroform toxicity in mice: correlation of renal and hepatic necrosis with covalent binding of metabolites to tissue macromolecules, Exp. Mol. Pathol., 19 (1973) 215-229.

101 Irving, C.C., and R.A. Veazey, Persistent binding of 2-acetylaminofluorene to rat liver DNA in vivo and consideration of the mechanism of binding of $N$ hydroxy-2-acetylaminofluorene to rat liver nucleic acids, Cancer Res., 29 (1969) 1799-1804.

102 Irving, C.C., T.C. Peeler, R.A. Veazey and R. Wiseman Jr., Influence of 3-methylcholanthrene and diet on the binding of 2 -acetylaminofluorene and its $N$-hydroxy metabolite to rat liver nucleic acids, Cancer Res., 31 (1971) 1468-1472.

103 Irving, C.C., Interaction of chemical carcinogens with DNA, in: H. Busch (Ed.), Methods in Cancer Research, Vol. VII, Academic Press, New York, 1973, pp. 189-244.

104 Irving, C.C.. Influence of the aryl group on the reaction of glucuronides of $N$-arylacethydroxamic acids with polynucleotides, Cancer Res., 37 (1977) $524-528$.

105 Jacob, S.W., and R. Herschler (Eds.), Biological Actions of Dimethyl Sulfoxide, Ann. N.Y. Acad. Sci., Vol. 243 (1975).

106 Jaggi, W., W.K. Lutz and C. Schlatter, Comparative studies on the covalent binding of the carcinogen benzo[a]pyrene to DNA in various model systems, Experientia, 35 (1979) 631-632.

107 Jaggi, W., W.K. Lutz and C. Schlatter, Covalent binding of ethinylestradiol and estrone to rat liver DNA in vivo, Chem,-Biol. Interact., 23 (1978) 13-18.

108 Jakubowski. T., Binding of [Cl-36]-dieldrin to suspected target- and non-target proteins in vitro, Bull. Environ. Contam. Toxicol., 10 (1973) 217-224.

109 Janss, D.H., R.C. Moon and C.C. Irving, The binding of 7,12-dimethylbenz[a] anthracene to mammary parenchyma DNA and protein in vivo, Cancer Res., 32 (1972) 254-258.

110 Janss, D.H., and C.C. Irving, Radioactivity in rat mammary gland after the administration of 2-acetylaminofluorene-9-[C-14] and its $N$-hydroxy metabolite, J. Natl. Cancer Inst., 49 (1972) 765-771.

111 Janss, D.H., and T.L. Ben, Age-related modification of 7,12-dimethylbenz $[a]$ anthracene binding to rat mammary gland DNA, J. Natl. Cancer Inst., 60 (1978) 173-177.

112 Järvisalo, J., H. Savolainen, E. Elovaara and H. Vainio, The in vivo toxicity of carbon disulphide to liver microsomes: binding of labelled carbon disulphide and changes of the microsomal enzyme activities, Acta Pharmacol. Toxicol., 40 (1977) 329-336.

113 Jernström, B., H. Vadi and S. Orrenius, Formation in isolated rat liver microsomes and nuclei of benzo[a]pyrene metabolites that bind to DNA, Cancer Res., 36 (1976) $4107-4113$.

114 Jollow, D.J., J.R. Mitchell, N. Zampaglione and J.R. Gillette, Bromobenzene-induced liver necrosis, Protective role of glutathione and evidence for 3,4-bromobenzene oxide as the hepatotoxic metabolite, Pharmacology, 11 (1974) 151-169.

115 Kadlubar, F.F., J.A. Miller and E.C. Miller, Hepatic microsomal $N$-glucuronidation and nucleic acid binding of $N$-hydroxyarylamines in relation to urinary bladder carcinogenesis, Cancer Res., 37 (1977) 805-814.

116 Kadlubar, F.F., J.A. Miller and E.C. Miller, Reactivity of the carcinogen $N$-hydroxy-1-naphthylamine with nucleic acids, Proc. Am. Ass. Cancer Res., 18 (1977) 30.

117 Kamataki, T., and R.A. Neal, Metabolism of diethyl-p-nitrophenyl-phosphorothionate (parathion) by a reconstituted mixed-function oxidase enzyme system: studies of the covalent binding of the sulfur atom, Mol. Pharmacol., 12 (1976) 933-944.

118 Kappus, H., Irreversible protein binding of [C-14]imipramine in rats in vivo, Arch. Toxicol., 37 (1976) 75-80.

119 Kittler, L., Z. Hradecna and G. Lober, Photochemically induced binding of furocoumarins with lambda phage DNA in situ, Stud. Biophys., 66 (1977) 237-241.

120 Kleihues, P., K. Patzschke, G.P. Margison, L.A. Wegner and C. Mende, Reaction of methyl methane- 
sulphonate with nucleic acids of fetal and newborn rats in vivo, Z. Krebsforsch.. 81 (1974) 273283.

121 Kleihues, P., J.M. Margison and G.P. Margison, Dimethylnitrosamine-induced inhibition of hepatic protein synthesis in vitro and the effect of pretreatment with cystamine or pregnenolone-16 $\alpha$-carbonitrile, Cancer Res., 35 (1975) 3667-3672.

122 Kleihues, P., and G.P. Margison, Exhaustion and recovery of repair excision of $O(6)$-methylguanine from rat liver DNA, Nature (London), 259 (1976) 153-155.

123 Kleihues, P., G.F. Kolar and G.P. Margison, Interaction of the carcinogen 3,3-dimethyl-1-phenyltriazene with nucleic acids of various rat tissues and the effect of a protein-free diet, Cancer Res., 36 (1976) 2189-2193.

124 Konopa, J., K. Koldej and J.W. Pawlak, Covalent binding of 1-nitro-9-(3'-dimethyl-n-propylamino)acridine, a new antitumor drug, to DNA of Ehrlich ascites tumor cells in vivo, Chem.-Biol. Interact., $13(1976) 99-103$

125 Koreeda. M., P.D. Moore, P.G. Wislocki, W. Levin, A.H. Conney, H. Yagi and D.M. Jerina, Binding of benzo[ $a$ ]pyrene 7,8-diol-9,10-epoxides to DNA, RNA, and protein of mouse skin occurs with high stereoselectivity, Science, 199 (1978) $778-781$.

126 Kriek, E., On the mechanism of action of carcinogenic aromatic amines, I. Binding of 2-acetylaminofluorene and $N$-hydroxy-2-acetylaminofluorene to rat liver nucleic acids in vivo, Chem.-Biol. Interact., $1(1969 / 70) 3-17$.

127 Kriek, E., On the mechanism of action of carcinogenic aromatic amines, II. Binding of $N-h y d r o x y-$ $N$-acetyl-4-aminobiphenyl to rat liver nucleic acids in vivo, Chem.-Biol. Interact., 3 (1971) $19-28$.

128 Kriek, E., Persistent binding of a new reaction product of the carcinogen $N$-hydroxy- $N$-2-acetylaminofluorene with guanine in rat liver DNA in vivo, Cancer Res., 32 (1972) 2042-2048.

129 Kriek, E., and G.M. Hengeveld, Reaction products of the carcinogen $N$-hydroxy-4-acetylamino-4'fluorobiphenyl with DNA in liver and kidney of the rat. Chem.-Biol. Interact., 21 (1978) 179-201.

130 Krishna, G., Covalent binding of drugs to tissue macromolecules as a biochemical mechanism of drug toxicities with special emphasis on chloramphenicol and thiamphenicol, Postgrad. Med. J., Suppl., 50 (1974) 73-77.

131 Kwiram, A.L., Y.C. Liu, M.N. Farquhar and E.A. Smuckler, Binding of aflatoxin to DNA as studied by optical detection of magnetic resonance, Biochem. Biophys. Res. Commun., 83 (1978) 13541359.

132 Labadorios, D., M. Davis, B. Portmann and R. Williams, Paracetamol-induced hepatic necrosis in the mouse - Relationship between covalent binding, hepatic glutathione depletion and the protective effect of $\alpha$-mercaptopropionylgly cine, Biochem. Pharmacol., 26 (1977) 31-35.

133 Lang, M.C.E., R.P.P. Fuchs and M.P. Daune, Secondary structural modifications as a consequence of in vitro acetylation and phenanthrylation of DNA by the ultimate carcinogen $N$-acetoxy- $N$-2-acetylaminophenanthrene, Cancer Res., 37 (1977) 3887-3891.

134 Lang, M.C.E., R.P.P. Fuchs and M.P. Daune, In vitro covalent binding to DNA of the ultimate carcinogen $N$-acetoxy- $N-4$-acetylaminobiphenyl, FEBS Lett., 81 (1977) 101-104.

135 Lawley, P.D., Effects of some chemical mutagens and carcinogens on nucleic acids, in: J.N. Davidson and W.E. Cohn (Eds.), Progress in Nucleic Acid Research and Molecular Biology, Vol. 5, Academic Press, New York, 1966, pp. 89-131.

136 Lawley, P.D., P. Brookes, P.N. Magee, V.M. Craddock and P.F. Swann, Methylated bases in liver nucleic acids from rats treated with dimethylnitrosamine, Biochim. Biophys. Acta, 157 (1968) 646648.

137 Lawley, P.D., S.A. Shah and D.J. Orr. Methylation of nucleic acids by 2,2-dichlorovinyl dimethyl phosphate (dichlorvos, DDVP), Chem.-Biol. Interact., 8 (1974) 171-182.

138 Lawley, P.D., Methylation of DNA by carcinogens: some applications of chemical analytical methods, in: R. Montesano et al. (Eds.), Screening Tests in Chemical Carcinogenesis, IARC Scientific Publications No. 12, International Agency for Research on Cancer, Lyon, Fance, 1976, pp. 181-208.

139 Lawley, P.D., Carcinogenesis by alkylating agents, in: C.E. Searle (Ed.), Chemical Carcinogens, ACS Monograph 173, American Chemical Society, Washington, D.C., 1976, pp. 83-244.

140 Lawson, T.A., The effect of prolonged feeding of 0 -aminoazotoluene on the binding to cellular constituents in mouse liver, Chem.-Biol. Interact., 2 (1970) 9-16.

141 Lawson, T.A., and F.K. Dzhioev, The binding of $o$-aminoazotoluene in proliferating tissues, Chem.Biol. Interact., 2 (1970) 165-174.

142 Lawson, T.A., and A.W. Pound, The reaction of urethane with mouse liver nucleic acids in vivo, Pathology, 3 (1971) 223-225.

143 Lawson, T.A., and A.W. Pound, The interaction of [H-3]ethyl carbamate with nucleic acids of regenerating mouse liver, Chem.-Biol. Interact., 4 (1971/72) 329-341.

144 Lawson, T.A., The methylation of DNA in regenerating rat liver, $Z$. Krebsforsch., 90 (1977) 211214.

145 Lee, K.Y., and C.M. Goodall, Methylation of ribonucleic acid and deoxyribonucleic acid and tumour induction in livers of hypophysectomized rats treated with dimethylnitrosamine, Biochem. J., 106 (1968) $767-768$. 
146 Legator, M.S., and W.G. Flamm, Environmental mutagenesis and repair, Annu. Rev, Biochem., 42 (1973) 683-708.

147 Lijinsky, W., and A.E. Ross, Alkylation of rat liver nucleic acids not related to carcinogenesis by $N$-nitrosamines, J. Natl. Cancer Inst., 42 (1969) $1095-1100$.

148 Lijinsky, W., K.Y. Lee and C.H. Gallagher, Interaction of aflatoxins B1 and G1 with tissues of the rat, Cancer Res., 30 (1970) $2280-2283$.

149 Lijinsky, W., Interaction with nucleic acids of carcinogenic and mutagenic $N$-nitrosocompounds, in: W.E. Cohn (Ed.), Progress in Nucleic Acid Research and Molecular Biology, Vol. 17, Academic Press, New York, 1976, pp. 247-269.

150 Likhachev, A.J., G.P. Margison and R. Montesano, Alkylated purines in the DNA of various rat tissues after administration of 1,2-dimethylhydrazine, Chem.-Biol. Interact., 18 (1977) 235-240.

151 Lin, J.-K., J.A. Miller and E.C. Miller, Structures of hepatic nucleic acid-bound dyes in rats given the carcinogen $N$-methyl-4-aminoazobenzene, Cancer Res., 35 (1975) 844-850.

152 Lin, J.-K., J.A. Miller and E.C. Miller, 2,3-Dihydro-2-(guan-7-yl)-3-hydroxyaflatoxin B1, a major acid hydrolysis product of aflatoxin B1-DNA or -ribosomal RNA adducts formed in hepatic microsome-mediated reactions and in rat liver in vivo, Cancer Res., 37 (1977) 4430-4438.

153 Lin, S.S., and T.L. Dao, Binding of polycyclic hydrocarbons to rat mammary gland cellular macromolecules in vivo, Proc. Soc. Exp. Biol. Med., 138 (1971) 814-816.

154 Lorusso, D.J., and J.W. Suttie, Warfarin binding to microsomes isolated from normal and warfarinresistant rat liver, Mol. Pharmacol., 8 (1972) 197-203.

155 Loveless, A., Possible relevance of $O(6)$-alkylation of deoxyguanosine to the mutagenicity and carcinogenicity of nitrosamines and nitrosamides, Nature (London), 223 (1969) 206-207.

156 Lutz, W.K., and C. Schlatter, A closed inhalation chamber for quantitative metabolism studies of volatile compounds with small laboratory animals, Toxicol. Lett., 1 (1977) 83-87.

157 Lutz, W.K. and C. Schlatter, Mechanism of the carcinogenic action of benzene: irreversible binding to rat liver DNA, Chem.-Biol. Interact., 18 (1977) 241-245.

$158 \mathrm{Lutz}$, W.K., and C. Schlatter, Saccharin does not bind to DNA of liver or bladder in the rat, Chem.Biol. Interact., 19 (1977) 253-257.

159 Lutz, W.K., A. Viviani and C. Schlatter, Nonlinear dose-response relationship for the binding of the carcinogen benzo[ $a$ ]pyrene to rat liver DNA in vivo, Cancer Res., 38 (1978) 575-578.

160 Magee, P.N., and E. Farber, Toxic liver injury and carcinogenesis, Methylation of rat-liver nucleic acids by dimethylnitrosamine in vivo, Biochem. J., 83 (1962) 114-124.

161 Magee, P.N., A.E. Pegg and P.F. Swann, Molecular mechanisms of chemical carcinogenesis, in: E. Grundmann (Ed.), Handbuch der allgemeinen Pathologie, Vol. VI/6, Springer, Berlin, 1975, pp. $329-419$.

162 Magin, M.N., P.J. O'Connor and A.W. Craig, The effect of hormone induced stress upon the extent of alkylation of rat liver nucleic acids by $N$-methyl- $N$-nitrosourea, $Z$. Krebsforsch., 84 (1975) 217222.

163 Malaveille, C., B. Duperray, H. Pacheco and L. Tomatis, Distribution tissulaire, infracellulaire et fixation du [C-14] MCA ou de ses derives sur les constituants cellulaires chez les souris meres, les foetus et les neonates, Chem.-Biol. Interact., 7 (1973) $79-92$.

164 Manthey, B., W.K. Lutz, E. L'Eplattenier, C. Schlatter and F. Würgler, Binding of the carcinogens benzo[a]pyrene and 7,12-dimethylbenz[a]anthracene to Salmonella DNA as compared to the corresponding mutagenicity, Experientia, 34 (1978) 927.

165 Margison, G.P., and P. Kleihues, Preferential accumulation of $O(6)$-methylguanine in rat brain deoxyribonucleic acid during repetitive administration of $N$-methyl- $N$-nitrosourea, Biochem. J., 148 (1975) $521-525$.

166 Maxkov, G.G., and I.G. Ivanov, Hydroxyapatite column chromatography in procedures for isolation of purified DNA. Anal. Biochem., 59 (1974) 555-563.

167 Marquardt, H., A. Bendich, F.S. Philips and D. Hoffmann, Binding of $[G-H-3]-7,12-d i m e t h y l b e n z[a]-$ anthracene to DNA of normal and rapidly dividing hepatic cells of rats, Chem.-Biol. Interact., 3 (1971) $1-11$.

168 Marquardt, H., F.S. Philips and A. Bendich, DNA binding and inhibition of DNA synthesis after 7,12-dimethylbenz [a]anthracene administered during the early prereplicative phase in regenerating rat liver, Cancer Res., 32 (1972) 1810-1813.

169 Matsushima, T., and J.H. Weisburger, Inhibitors of chemical carcinogens as probes for molecular targets: DNA as decisive receptor for metabolite from $N$ hydroxy- $N-2$-fluorenylacetamide, Chem.Biol. Interact., $1(1969 / 70)$ 211-221.

170 Matsushima, T., P.H. Grantham, E.K. Weisburger and J.H. Weisburger, Phenobarbital-mediated increase in ring- and $N$-hydroxylation of the carcinogen $N$-2-fluorenylacetamide, and decrease in amounts bound to liver deoxyribonucleic acid, Biochem. Pharmacol., 21 (1972) 2043-2051.

171 Mattocks, A.R., Tissue distribution of radioactivity in rats given tritiated analogues of hepatotoxic pyrrolizidine alkaloids, Xenobiotica, 7 (1977) 665-670. 
172 McCann, J., E. Choi, E. Yamasaki and B.N. Ames, Detection of carcinogens as mutagens in the Salmonella/microsome test: assay of 300 chemicals, Proc. Natl. Acad. Sci. (U.S.A.), 72 (1975) 51355139.

173 McCann, J., and B.N. Ames, Detection of carcinogens as mutagens in the Salmonella/microsome test: assay of 300 chemicals: discussion, Proc. Natl. Acad. Sci. (U.S.A.), 73 (1976) 950-954.

174 McGregor, D., Effects of methylcholanthrene on 2-acetamidofluorene association with liver cell components, Biochem. Pharmacol., 22 (1973) 3136-3139.

175 Meselson, M., and K. Russell, Comparisons of carcinogenic and mutagenic potency, in: H.H. Hiatt et al. (Eds.), Origins of Human Cancer, Book C, Cold Spring Harbor Conferences on Cell Proliferation, Vol. 4, Cold Spring Harbor Laboratory, 1977, pp. 1473-1481.

176 Metzger, G., F.X. Wilhelm and M.L. Wilhelm, Non-random binding of a chemical carcinogen to the DNA in chromatin, Biochem. Biophys. Res. Commun., 75 (1977) 703-710.

177 Miller, E.C., and J.A. Miller, The presence and significance of bound aminoazo dyes in the livers of rats fed $p$-dimethylaminoazobenzene, Cancer Res., 7 (1947) 468-480.

178 Miller, J.A., Carcinogenesis by chemicals: an overview - G.H.A. Clowes memorial lecture, Cancer Res., 30 (1970) 559-576.

179 Miller III, A., M.C. Henderson and D.R. Buhler, Cytochrome P-450-mediated covalent binding of hexachlorophene to rat tissue proteins, Mol. Pharmacol., 14 (1978) 323-336.

180 Montesano, R., H. Bartsch and L. Tomatis (Eds.), Screening Tests in Chemical Carcinogenesis, IARC Scientific Publications No. 12, International Agency for Research on Cancer, Lyon, France, 1976.

181 Moyer, G.H., B. Gumbiner and G.E. Austin, Binding of $N$-hydroxy acetylaminofluorene to eu- and hetero-chromatin fractions of rat liver in vivo, Cancer Lett., 2 (1977) 259-266.

182 Mulder, G.J., J.A. Hinson and J.R. Gillette, Generation of reactive metabolites of $N$-hydroxy-phenacetin by glucuronidation and sulfation, Biochem. Pharmacol., 26 (1977) 189-196.

183 Munsch, N., F. Marano and C. Frayssinet, Incorporation d'acroleine [H-3] dans le foie du rat et chez Dunaliella bioculata, Biochimie, 56 (1974) $1433-1436$.

184 Mushlin, P.S., and C. Peraino, Effects of dietary phenobarbital on the binding of 2-acetylaminofluorene to rat liver nuclear DNA, Proc. Soc. Exp. Biol. Med., 145 (1974) 859-862.

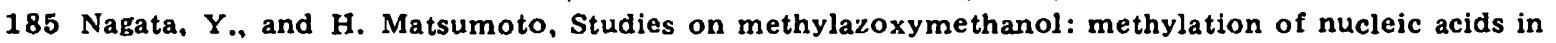
the fetal rat brain, Proc. Soc. Exp. Biol. Med., 132 (1969) 383-385.

186 Neal, G.E., and H.M. Godoy. The effect of pretreatment with phenobarbitone on the activation of aflatoxin B1 by rat liver, Chem.-Biol. Interact., 14 (1976) 279-289.

187 Nelson, S.D., Isoniazid and iproniazid: activation of metabolites to toxic intermediates in man and rat, Science, 193 (1976) 901-903.

188 Nelson, J.O.. R.E. Menzer, P.C. Kearney and J.R. Plimmer, 2,3,7,8-Tetrachlorodibenzo-p-dioxin: in vitro binding to rat liver microsomes, Bull. Environ. Contam. Toxicol., 18 (1977) 9-13,

189 Nery, R., and E. Nice, Metabolism and binding of [C-14]mycophenolic acid in the rat, J. Pharm. Pharmacol., 23 (1971) 842-847.

190 Neumann, H.-G., Pharmacokinetic parameters influencing tissue specificity in chemical carcinogenesis, Arch. Toxicol., Suppl. 2 (1979) 229-238.

191 Newbold, R.F., C.B. Wigley, M.H. Thompson and P. Brookes, Cell-mediated mutagenesis in cultured Chinese hamster cells by carcinogenic polycyclic hydrocarbons: nature and extent of the associated hydrocarbon-DNA reaction, Mutation Res., 4.3 (1977) 101-116.

192 Nicoll, J.W., P.F. Swann and A.E. Pegg, Ef fect of dimethylnitrosamine on persistence of methylated guanines in rat liver and kidney DNA, Nature (London), 254 (1975) 261-262.

193 Nicoll, J.W., P.F. Swann and A.E. Pegg. The accumulation of $O(6)$-methylguanine in the liver and kidney DNA of rats treated with dimethylnitrosamine for a short or a long period, Chem.-Biol. Interact., 16 (1977) 301-308.

194 O'Connor, P.J., M.J. Capps and A.W. Craig, Comparative studies of the hepatocarcinogen $N, N$-dimethylnitrosamine in vivo: reaction sites in rat liver DNA and the significance of their relative stabilities, Br. J. Cancer, 27 (1973) 153-166.

195 O'Connor, P.J., G.P. Margison and A.W. Craig, Phosphotriesters in rat liver deoxyribonucleic acid after the administration of the carcinogen $N, N$-dimethylnitrosamine in vivo, Biochem. J., 145 (1975) 475-482.

196 Osborne, M.R., M.H. Thompson, H.W.S. King and P. Brookes, Retention of tritium during the binding of tritiated benzo[ $a$ ]pyrene to DNA, Int. J. Cancer, 16 (1975) 659-664.

197 Oscarson, J.E.A., R.C.N. Williamson, H.F. Veen, F.L.R. Bauer and R.A. Malt, Small-bowel resection enhances colonic carcinogenesis by dimethylhydrazine and azoxymethane, Proc. Am. Ass. Cancer Res., 18 (1977) 43.

198 Otten waelder, H., R.J. Laib and H.M. Bolt, Alkylation of RNA by vinyl bromide metabolites in vitro and in vivo, Arch. Toxicol., 41 (1979) 279-286.

199 Paul, J.S., and M.A. Pavelka, Covalent binding of a carcinogenic epoxide to DNA in vivo, Fed. Proc., 30 (1971) 448Abs. 
200 Pegg, A.E., and J.W. Nicol, Nitrosamine carcinogenesis: the importance of the persistence in DNA of alkylated bases in the orgunotropism of tumor induction, in: R. Montesano et al. (Eds.), Screening Tests in Chemical Carcinogenesis. IARC Scientific Publications No. 12, International Agency for Research on Cancer, Ly on, France, 1976, pp. 571-590.

201 Pegg, A.E., Alkylation of rat liver DNA by dimethylnitrosamine: effect of dosage on $O(6)$-methylguanine levels, J. Natl. Cancer Inst., 58 (1977) 681-687.

202 Pegg, A.E., Formation and metabolism of alkylated purines: possible role in carcinogenesis by $N$-nitrosocompounds and alkylating agents, Adv. Cancer Res., 25 (1977) 195-269.

203 Pegg, A.E., Dimethylnitrosamine inhibits enzymatic removal of $O(6)$-methylguanine from DNA, Nature (London), 274 (1978) 182-184.

204 Pegg, A.E., and G. Hui, Removal of methylated purines from rat liver DNA after administration of dimethylnitrosamine, Cancer Res., 38 (1978) 2011-2017.

205 Pegg, A.E., Inhibition of the alkylation of nucleic acids and of the metabolism of 1,2-dimethylhydrazine by aminoacetonitrile, Chem.-Biol. Interact., 23 (1978) 273-279.

206 Peraino, C., R.J.M. Fry, E. Staffeldt and J.P. Christopher, Enhancing ef fects of phenobarbitone and butylated hydroxytoluene on 2-acetylaminofluorene-induced hepatic tumorigenesis in the rat, Fd. Cosmet. Toxicol., 15 (1977) 93-96.

207 Phillips, D.H., P.L. Grover and P. Sims, The covalent binding of polycyclic hydrocarbons to DNA in the skin of mice of different strains, Int. J. Cancer, 22 (1978) 487-494.

208 Pound, A.W., F. Franke and T.A. Lawson. The binding of ethyl carbamate to DNA of mouse liver in vivo: the nature of the bound molecule and the site of binding, Chem.-Biol. Interact., 14 (1976) $149-163$.

209 Poynter, R.W., Studies on the mechanism of resistance to alkylating agents of three ascites tumors in the rat, Biochem. Pharmacol., 19 (1970) 1387-1397.

210 Pozharisski, K.M., Y.M. Kapustin, A.J. Likhachev and J.D. Shaposhnikov, The mechanism of carcinogenic action of 1,2-dimethylhydrazine in rats, Int. J. Cancer, 15 (1975) 673-683.

211 Preussmann, R., Chemische Carcinogene in der menschlichen Umwelt, in: E. Grundmann (Ed.), Handbuch der allgemeinen Pathologie, Vol. VI/6, Springer, Berlin, 1975, pp. 421-594.

212 Prodi, G., P. Rocchi and S. Grilli. Binding of 7,12-dimethylbenz[a] anthracene and benzo[a]pyrene to nucleic acids and proteins of organs in rats, Cancer Res., $30(1970) 1020-1023$.

213 Prodi, G., P. Rocchi and S. Grilli, In vivo reaction of urethan with nucleic acids and proteins, Cancer Res., 30 (1970) $2887-2892$.

214 Purchase, I.H.F., E. Longstaff, J. Ashby, J.A. Styles, D. Anderson, P.A. Lefevre and F.R. Westwood, Evaluation of six short term tests for detecting organic chemical carcinogens and recommendations for their use, Nature (London), 264 (1976) 624-627.

215 Rao, G.S., G. Krishna and J.R. Gillette, Metabolism, tissue distribution, and covalent binding of tripelennamine and its $N$-nitroso derivative in the rat, J. Pharmacol. Exp. Ther., 195 (1975) $433-440$.

216 Rao, G.S., A study of the mechanism of halothane-induced liver necrosis, Role of covalent binding of halothane metabolites to liver proteins in the rat, J. Med. Chem., 20 (1977) 262-265.

217 Regan, J.D., R.B. Setlow, A.A. Francis and W. Lijinsky, Nitrosocarbaryl: its effect on human DNA, Mutation Res., 38 (1976) 293-302.

218 Remmer, H., M. Scheulen, H. Kappus and H.M. Bolt, The significance of covalent binding of catechols to proteins in vivo, Arch. Toxicol., 39 (1977) 31-39.

219 Ricco, J.-B., D. Franco, J. Morin, F. Decloitre and H. Bismuth, Modifications of 3'-methyl-4-dimethylaminoazobenzene carcinogenesis of rat liver and carcinogen metabolism by portacaval anastomosis, Cancer Res. 37 (1977) 4500-4505.

220 Roberts, J.J., and G.P. Warwick, The covalent binding of metabolites of dimethylaminoazobenzene, $\beta$-naphthylamine and aniline to nucleic acids in vivo, Int. J. Cancer, 1 (1966) 179-196.

221 Rocchi, P., G. Prodi, S. Grilli and A.M. Ferreri, In vivo and in vitro binding of carbon tetrachloride with nucleic acids and proteins in rat and mouse liver, Int. J. Cancer, 11 (1973) $419-425$.

222 Rogan, E.G., P. Mailander and E. Cavalieri, Metabolic activation of aromatic hydrocarbons in purified rat liver nuclei: induction of enzyme activities and binding to DNA with and without monooxygenase-catalyzed formation of active oxygen, Proc. Natl. Acad. Sci. (U.S.A.), 73 (1976) 457461.

223 Rogers, K.J., and A.E. Pegg, Formation of $O(6)$-methylguanine by alkylation of rat liver, colon, and kidney DNA following administration of 1,2-dimethylhydrazine, Cancer Res., 37 (1977) 40824087.

224 Ross, A.E., L. Keefer and W. Lijinsky, Alkylation of nucleic acids of rat liver and lung by deuterated $N$-nitrosodie thylamine in vivo, J. Nat1. Cancer Inst., 47 (1971) 789-795.

225 Ross, A.E., and S.S. Mirvish, Metabolism of $N$-nitrosohexamethyleneimine to give 1,6-hexanediol bound to rat liver nucleic acids, J. Natl. Cancer Inst., 58 (1977) $651-655$.

226 Rotman, A., J.W. Daly and C.R. Creveling, Oxygen-dependent reaction of 6-hydroxydopamine, 5,6dihydroxy try ptamine, and related compounds with proteins in vitro: a model for cytotoxicity, Mol. Pharmacol., 12 (1976) 887-899. 
227 Ruddick, J.A., D.T. Williams, L. Hierlihy and K.S. Khera, [C-14]Ethylenethiourea: distribution, excretion, and metabolism in pregnant rats, Teratology, 13 (1976) 35-40.

228 Sarma, D.S.R., S. Rajalakshmi and E. Farber, Chemical carcinogenesis: interactions of carcinogens with nucleic acids, in: F.E. Becker (Ed.), Cancer, Vol. 1, Plenum, New York, 1975, pp. 235-287.

229 Savolainen, H., and H. Vainio, Organ distribution and nervous system binding of styrene and styrene oxide, Toxicology, 8 (1977) 135-141.

230 Scherer, E., A.P. Stewart and P. Emmelot, Kinetics of formation of $O(6)$-ethylguanine in, and its removal from liver DNA of rats receiving diethylnitrosamine, Chem.-Biol. Interact., 19 (1977) 1-11.

231 Scheulen, M., P. Wollenberg, H.M. Bolt, H. Kappus and H. Remmer, Irreversible binding of DOPA and dopamine metabolites to protein by rat liver microsomes, Biochem. Biophys. Res. Commun., 66 (1975) 1396-1400.

232 Schmaehl, D., Combination effects in chemical carcinogenesis (experimental results), Oncology, 33 (1976) 73-76.

233 Schmaehl, D., F.W. Kruger, M. Habs and B. Diehl, Influence of disulfiram on the organotropy of the carcinogenic effect of dimethylnitrosamine and diethylnitrosamine in rats, 2 . Krebsforsch., 85 (1976) 271-276.

234 Schoental, R., Methylation of nucleic acids by $N$-[C-14]methyl-N-nitrosourethane in vitro and in vivo, Biochem. J., 102 (1967) 5c-7c.

235 Scribner, J.D., and N.K. Naimy, Adducts between the carcinogen 2-acetamidophenanthrene and adenine and guanine of DNA, Cancer Res., 35 (1975) 1416-1421.

236 Sega, G.A., P.A. Gee and W.R. Lee, Dosimetry of the chemical mutagen ethyl methanesulfonate in spermatozoan DNA from Drosophila melanogaster, Mutation Res., 16 (1972) 203-213.

237 Sega, G.A., R.B. Cumming and M.F. Walton, Dosimetry studies on the ethylation of mouse sperm DNA after in vivo exposure to [H-3] ethyl methanesulfonate, Mutation Res., 24 (1974) 317-333.

238 Sega, G.A., and J.G. Owens, Ethylation of DNA and protamine by ethyl methanesulfonate in the germ cells of male mice and the relevancy of these molecular targets to the induction of dominant lethals, Mutation Res., 52 (1978) 87-106.

239 Setlow, R.B., Repair deficient human disorders and cancer, Nature (London), 271 (1978) $713-717$.

240 Shank, R.C., and P.N. Magee, Similarities between the biochemical actions of cycasin and dimethylnitrosamine, Biochem. J., 105 (1967) $521-527$.

241 Shimada. T., and R. Sato, Covalent binding in vitro of polychlorinated biphenyls to microsomal macromolecules, Biochem. Pharmacol., 27 (1978) 585-593.

242 Shooter, K.V., and T.A. Slade, The stability of methyl and ethyl phosphotriesters in DNA in vivo, Chem.-Biol. Interact., 19 (1977) 353-361.

243 Shooter, K.V., T.A. Slade and P.J. O'Connor, The formation and stability of methyl phosphotriesters in the DNA of rat tissues after treatment with the carcinogen $N, N$-dimethylnitrosamine, Chem.-Blol. Interact., 19 (1977) 363-367.

244 Singer, B., The chemical effects of nucleic acid alkylation and their relation to mutagenesis and carcinogenesis, in: W.E. Cohn (Ed.), Progress in Nucleic Acid Research and Molecular Biology, Vol. 15. Academic Press, New York, 1975, pp. $219-284$.

245 Singer, B., All oxygens in nucleic acids react with carcinogenic ethylating agents, Nature (London), 264 (1976) 333-339.

246 Sipes, I.G., G. Krishna and J.R. Gillette, Bioactivation of carbon tetrachloride, chloroform and bromotrichloromethane: role of cytochrome P-450, Life Sci., 20 (1977) 1541-1548.

247 Skibba, J.L., and G.T. Bryan, Methylation of nucleic acids and urinary excretion of [C-14] tabeled 7-methylguanine by rats and man after administration of 4(5)-(3,3-dimethyl-1-triazeno)-imidazole 5(4)-carboxomide, Toxicol. Appl. Pharmacol., 18 (1971) 707-719.

248 Slaga, T.J., and W.M. Bracken. The effects of antioxidants on skin tumor initiation and aryl hydrocarbon hydroxylase, Cancer Res., 37 (1977) 1631-1635.

249 Slaga, T.J., et al. (Eds.), Mechanisms of Tumor Promotion and Cocarcinogenesis, Carcinogenesis A Comprehensive Survey, Vol. 2, Raven, New York, 1978.

250 Sneider, T.W., DNA : replication, modification, and repair, in: H. Busch (Ed.), The Molecular Biology of Cancer, Academic Press, New York, 1974, pp. 107-186.

251 Sonnenbichler, J., and F. Reichhart. Wechselwirkung von p-Dimethylaminoazobenzol mit Nichthistoprotein aus Rattenleberchromatin, Z. Krebsforsch., 91 (1978) 55-61.

252 Sosnowski, S.A., S. Rajalakshmi and D.S.R. Sarma, Protection by dimethylsulfoxide of strand breaks in hepatic DNA induced by dimethylnitrosamine, Chem.-Biol. Interact., 15 (1976) 101-104.

253 Speiex, J.L., and L.W. Wattenberg, Alterations in microsomal metabolism of benzo[ $a$ ]pyrene in mice fed butylated hydroxyanisole, J. Natl. Cancer Inst., 55 (1975) $469-472$.

254 Speier, J.L., L.K.T. Lam and L.W. Wattenberg, Effects of administration to mice of butylated hydroxyanisole by oral intubation on benzo[ $a]$ pyrene-induced pulmonary adenoma formation and metabolism of benzo[a]pyrene, J. Natl. Cancex Inst., 60 (1978) 605-609.

255 Sporn, M.B., and C.W. Dingman, 2-Acetamidofluorene and 3-methylcholanthrene: differences in binding to rat liver deoxyribonucleic acid in vivo, Nature (London), 210 (1966) $531-532$ 
256 Stekol, J.A., U. Mody and J. Perry, The incorporation of the carbon of the ethyl group of ethionine into liver nucleic acids and the effect of ethionine feeding on the content of nucleic acids in rat liver, J. Biol. Chem., 235 (1960) PC59-PC60.

257 Stewart, B.W., P.F. Swann, J.W. Holsman and P.N. Magee, Cellular injury and carcinogenesis, Evidence for the alkylation of rat liver nucleic acids in vivo by $N$-nitrosomorpholine, $Z$. Krebsforsch., 82 (1974) 1-12.

258 Stoltz, D.R., L.A. Poirier, C.C. Irving, H.F. Stich, J.H. Weisburger and H.C. Grice, Evaluation of short-term-tests for carcinogenicity, Toxicol. Appl. Pharmacol., 29 (1974) 157-180.

259 Stutman, O., Immunodepression and malignancy, Adv. Cancer Res., 22 (1975) 261-422.

260 Süss, R., and H.R. Maurer, Reduced binding of carcinogenic hydrocarbons to DNA of mouse skin during inhibition of DNA synthesis, Nature (London), 217 (1968) 752-753.

261 Swann, P.F., and P.N. Magee, Nitrosamine-induced carcinogenesis, The alkylation of nucleic acids of the rat by $N$-methyl- $N$-nitrosourea, dimethylnitrosamine, dimethyl sulphate and methyl methanesulphonate, Blochem. J., 110 (1968) 39-47.

262 Swann, P.F., and P.N. Magee, Nitrosamine-induced carcinogenesis, The alkylation of N-7 of guanine of nucleic acids of the rat by diethylnitrosamine, $N$-ethyl- $N$-nitrosourea and ethyl methanesulphonate, Biochem. J., 125 (1971) 841-847.

263 Swann, P.F., A.E. Pegg, A. Hawks, E. Farber and P.N, Magee, Evidence for ethylation of rat liver deoxyribonucleic acid after administration of ethionine, Biochem. J., 123 (1971) 175-181.

264 Swenberg, J.A., H.K. Cooper, J. Buecheler and P. Kleihues, 1, 2-Dimethylhydrazine-induced methylation of DNA bases in various rat organs and the effect of pretreatment with disulfiram, Cancer Res., 39 (1979) $465-467$.

265 Swenson, D.H., J.-K. Lin, E.C. Miller and J.A. Miller, Aflatoxin B1-2,3-oxide as a probable intermediate in the covalent binding of aflatoxins $\mathrm{B1}$ and $\mathrm{B2}$ to rat liver DNA and ribosomal RNA in vivo, Cancer Res., 37 (1977) $172-181$.

266 Szafarz, D., and J.H. Weisburger, Stability of binding of label from $N$-hydroxy-N-2-fluorenylacetamide to intracellular targets, particularly deoxyribonucleic acid in rat liver, Cancer Res., 29 (1969) $962-968$.

267 Szybalski, W., and V.N. Iyer, Crosslinking of DNA by enzymatically or chemically activated mitomycins and porfiromycins, bifunctionally "alkylating" antibiotics, Fed. Proc., 23 (1964) 946-957.

268 Tabarelli-Poplawski, S., and H. Uehleke, Irreversible binding of 3-[C-14]-antipxrine to bepatic protein in vivo and in metabolizing liver microsomes, Naunyn-Schmiedeberg's Arch. Pharmakol., 297 (1977) 105-110.

269 Tada, M., M. Tada and T. Takahashi, Interaction of a carcinogen, 4-hydroxyaminoquinoline-1oxide with nucleic acids, Biochem. Biophys. Res. Commun., 29 (1967) 469-477.

270 Tew, K.D., and D.M. Taylor, Studies with cyclophosphamide labeled with phosphorus-32 : nucleic acid alkylation and its effect on DNA synthesis in rat tumor and normal tissues, J. Natl. Cancer Inst., 58 (1977) 1413-1419.

271 Thorgeirsson, S.S., and P.J. Wirth, Covalent binding of foreign chemicals to tissue macromolecules, J. Toxicol. Environ. Health, 2 (1977) $873-881$.

272 Tomasz, M., C.M. Mercado, J. Olson and N. Chatterjie, Mode of interaction of mitomycin C with deoxyribonucleic acid and other polynucleotides in vitro, Biochemistry, 13 (1974) 4878-4887.

273 Trams, E.G., M.V. Nadkami and P.K. Smith, On the mechanism of action of the alkylating agents, I. Interaction of alkylating agents with nucleic acids, Cancer Res., 21 (1961) 560-566.

274 Uehleke, H., The model system of microsomal drug activation and covalent binding to endoplasmic proteins, in: W.A.M. Duncan (Ed.), Experimental Model Systems in Toxicology and their Significance in Man, Excerpta Medica, Amsterdam, 1974, pp. 119-129.

275 Uehleke, H., T. Werner, H. Greim and M. Krämer, Metabolic activation of haloalkanes and tests in vitro for mutagenicity, Xenobiotica, 7 (1977) 393-400.

276 Uehleke, H., and S. Poplaw ski-Tabarelli, Irreversible binding of [C-14]-labelled trichloroethylene to mice liver constituents in vivo and in vitro, Arch. Toxicol., 37 (1977) 289-294.

277 Viviani, A., and W.K. Lutz, Modulation of the binding of the carcinogen benzo[ $a$ ]pyrene to rat liver DNA in vivo by selective induction of microsomal and nuclear aryl hydrocarbon hydroxylase activity, Cancer Res., 38 (1978) 4640-4644.

278 Warwick, G.P., and J.J. Roberts, Persistent binding of butter yellow metabolites to rat liver DNA, Nature (London), 213 (1967) $1206-1207$.

279 Warwick, G.P., The covalent binding of metabolites of tritiated 2-methyl-4-dimethylaminoazobenzene to rat liver nucleic acids and proteins, and the carcinogenicity of the unlabelled compound in partially hepatectomised rats, Eur. J. Cancer, 3 (1967) 227-233.

280 Watanabe, P.G., J.A. Zempel, D.G. Pegg and P.J. Gehring, Hepatic macromolecular binding following exposure to vinyl chloride, Toxicol. Appl. Pharmacol., 44 (1978) 571-579.

281 Wattenberg, L.W., Inhibitors of chemical carcinogenesis, Adv. Cancer Res., 26 (1978) $197-226$.

282 Weisburger, J.H., and G.M. Williams, Metabolism of chemical carcinogens, in: F.F. Becker (Ed.), Cancer, Vol. 1, Plenum, New York, 1975, pp. 185-234. 
283 Westra, J.G., E. Kriek and H. Hittenhausen, Identification of the persistently bound form of the carcinogen $N$-acetyl-2-aminofluorene to rat liver DNA in vivo, Chem.-Biol. Interact., 15 (1976) 149164.

284 Wheeler, G.P., and H.E. Skipper, Studies with mustards, III. In vivo fixation of C-14 from nitrogen mustard-C-14-methyl in nucleic acid fractions of animal tissues, Arch. Biochem. Biophys., 72 (1957) $465-475$.

285 Wheeler, G.P., and J.A. Alexander, Studies with mustards, IV. Effects of nitrogen mustard treatment of deoxyribonuclease and deoxyribonucleic acid upon the enzymic degradation of deoxyribonucleic acid, Arch. Biochem. Biophys., 72 (19.57) $476-484$.

286 Wirth, P.J., C.J. Bettis and W.L. Nelson, Microsomal metabolism of furosemide, Evidence for the nature of the reactive intermediate involved in covalent binding, Mol. Pharmacol., 12 (1976) 759768.

287 Wislocki, P.G., E.C. Miller, J.A. Miller, E.C. McCoy and H.S. Rosenkranz, Carcinogenic and mutagenic activities of safrole, $1^{\prime}$-hydroxysafrole, and some known or possible metabolites, Cancer Res., 37 (1977) 1883-1891.

288 Woo, Y.-T., M.F. Argus and J.C. Arcos, Tissue and subcellular distribution of [H-3]-dioxane in the rat and apparent lack of microsome-catalyzed covalent binding in the target tissue, Life Sci., 21 (1977) 1447-1456.

289 Wooder, M.F., A.S. Wright and L.J. King, In vivo alkylation studies with dichlorvos at practical use concentrations, Chem.-Biol. Interact., 19 (1977) 25-46.

290 Wunderlich, V., M. Schütt, M. Böttger and A. Graffi, Preferential alkylation of mitochondrial deoxyribonucleic acid by $N$-methyl- $N$-nitrosourea, Biochem. J., 118 (1970) 99-109.

291 Wunderlich, V., I. Tetzlaff and A. Graffi, Studies on nitrosodimethylamine: preferential methylation of mitochondrial DNA in rats and hamsters, Chem.-Biol. Interact., 4 (1971/72) 81-89.

292 Wynder, E.L., Nutrition and cancer, Fed. Proc., 35 (1976) 1309-1315.

293 Zachariah, P.K., T.J. Slaga, D.L. Berry, W.M. Bracken, S.G. Buty, C.M. Martinsen and M.R. Juchau, The ability of enteric bacteria to catalyze the covalent binding of bile acids and cholesterol to DNA and their inability to metabolize benzo[a]pyrene to a binding product and to known metabolites, Cancer Lett., 3 (1977) 99-105.

294 Zedeck, M.S., and G.B. Brown, Methylation of intestinal and hepatic DNA in rats treated with methylazoxymethanol acetate, Cancer, 40 (1977) 2580-2583.

295 Zeiger, R.S., R. Salomon, N. Kinoshita and A.C. Peacock, The binding of 9,10-dimethyl-1,2-benzanthracene to mouse epidermal satellite DNA in vivo, Cancer Res., 32 (1972) 643-647. 